\title{
INTERDISCIPLINARY
}

\section{REFLECTIONS ON}

THE INTERPLAY

BETWEEN
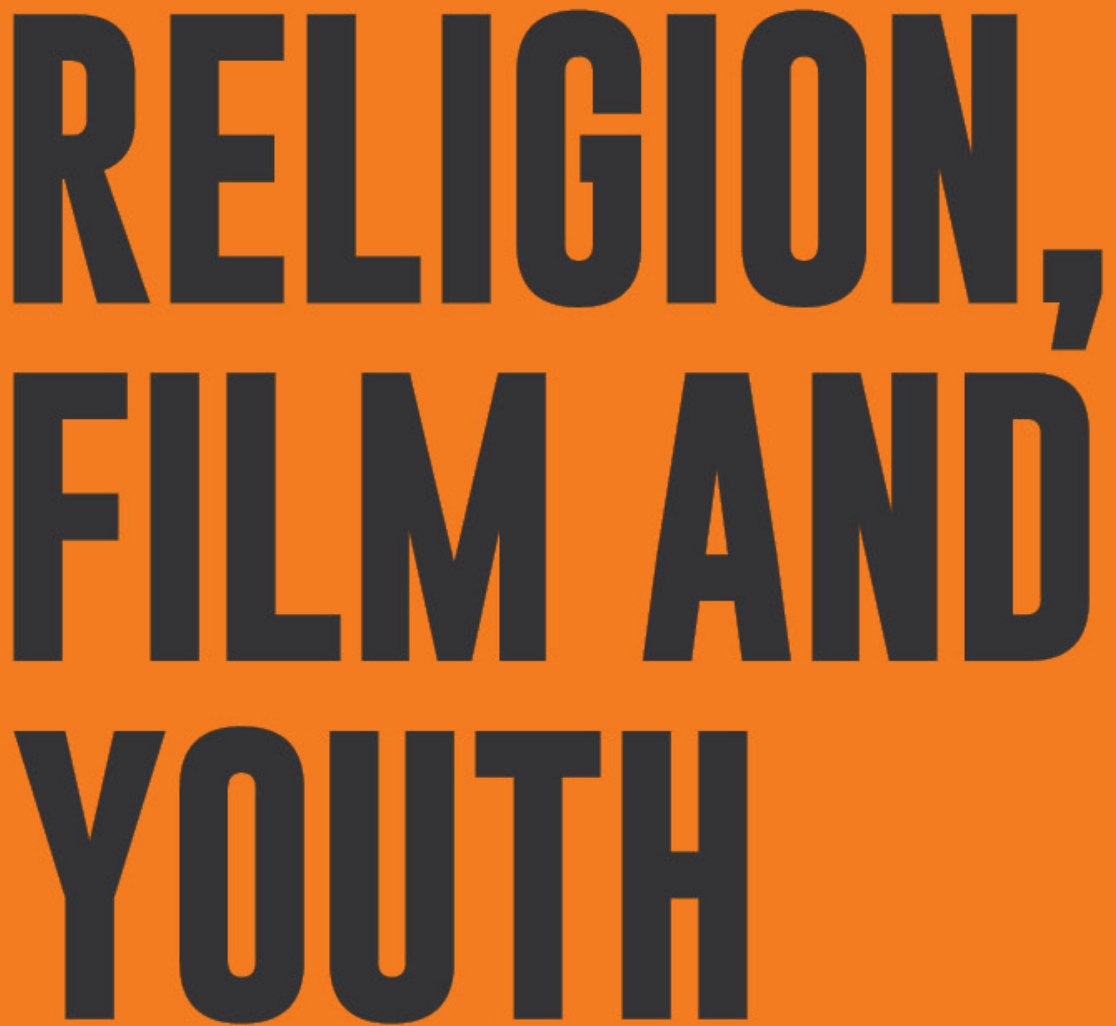

ANITA CLOETE (Ed) 


\section{INTERDISCIPLINARY REFLECTIONS ON THE INTERPLAY BETWEEN}

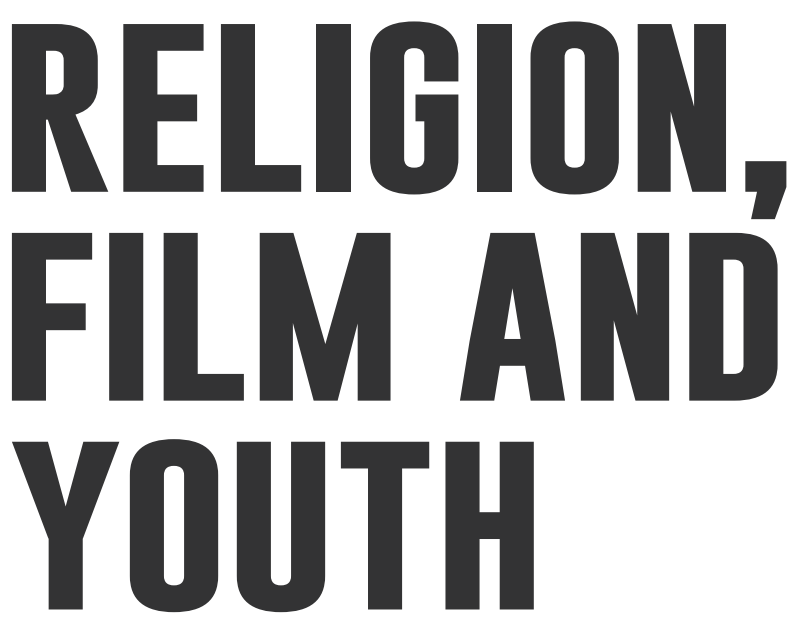

ANITA CLOETE (Ed)

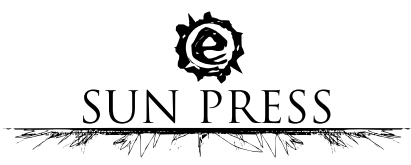




\section{Interdisciplinary Reflections on the Interplay between Religion, Film and Youth}

Published by AFRICAN SUN MeDIA under the SUN PReSS imprint

All rights reserved

Copyright (C) 2019 AFRICAN SUN MeDIA and the editor

This publication was subjected to an independent double-blind peer evaluation by the publisher.

The editor and the publisher have made every effort to obtain permission for and acknowledge the use of copyrighted material. Refer all enquiries to the publisher.

No part of this book may be reproduced or transmitted in any form or by any electronic, photographic or mechanical means, including photocopying and recording on record, tape or laser disk, on microfilm, via the Internet, by e-mail, or by any other information storage and retrieval system, without prior written permission by the publisher.

Views reflected in this publication are not necessarily those of the publisher.

First edition 2019

ISBN 978-1-928480-20-4

ISBN 978-1-928480-21-1 (e-book)

https://doi.org/10.18820/9781928480211

Set in AvantGarde CondBook 9.5/12.5

Cover design, typesetting and production by AFRICAN SUN MeDIA

SUN PReSS is a licensed imprint of AFRICAN SUN MeDIA. Scholarly, professional

and reference works are published under this imprint in print and electronic format.

This publication can be ordered directly from:

www.sun-e-shop.co.za

africansunmedia.store.it.si (e-books)

www.africansunmedia.co.za 

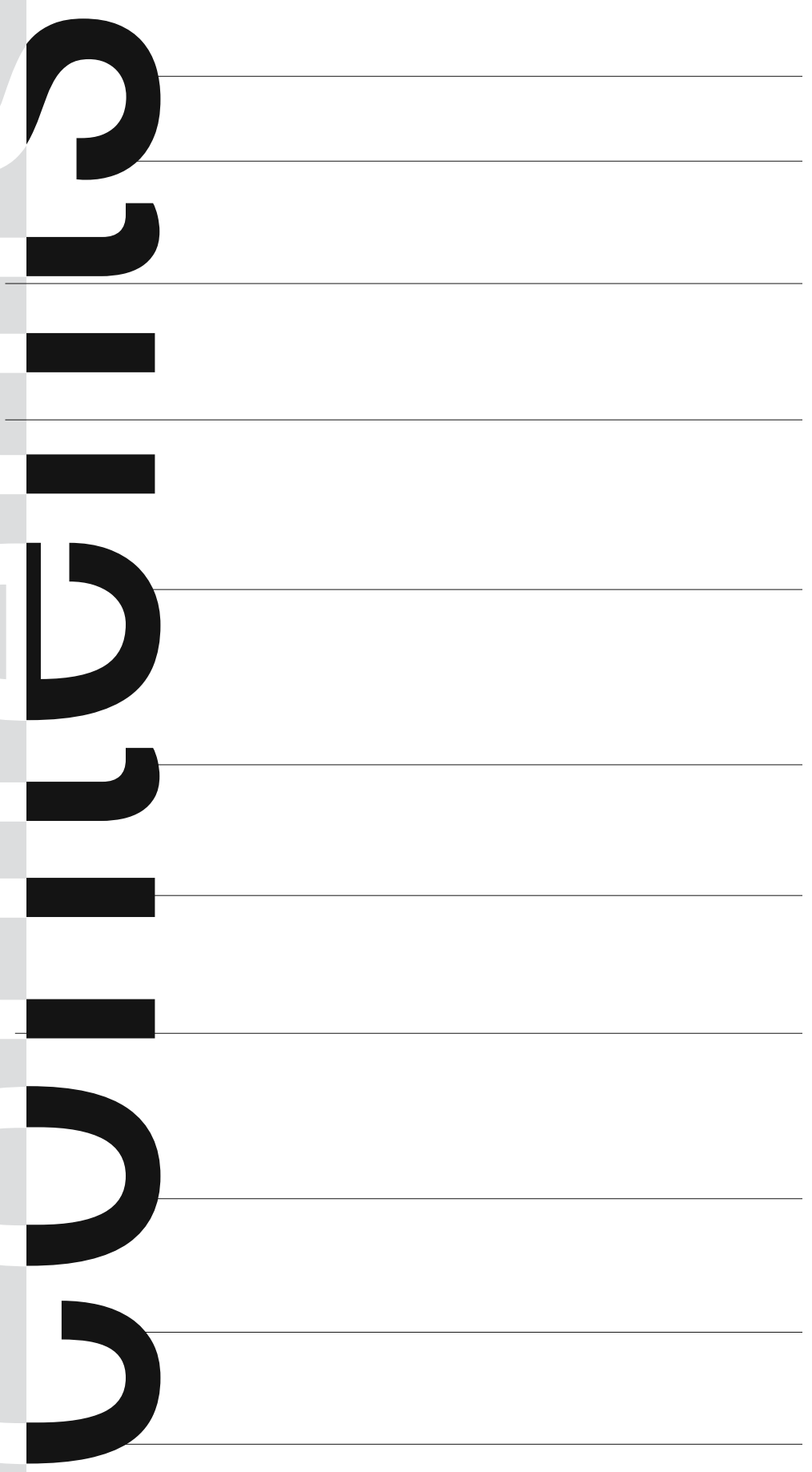


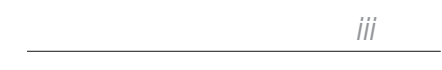

V

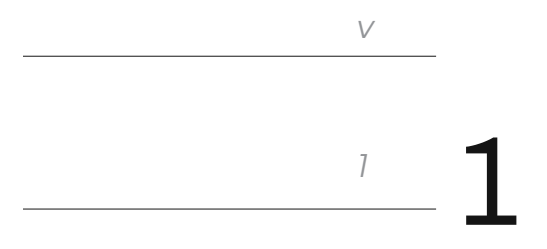

- 2

" 3

s. 4

65

75 Film as Discussion Platform

in Youth Ministry

Nathan Chiroma

Facilitating Holistic Identity Formation

of Adolescents using Digital Media:

A Dialogue between Media Literacy

and Catholic Religious Education

Edward Wright

Thick Viewing: Movies, Ethics and

Utopian Dreams of a Better World

Tomas Axelson

Religious Function of Film:

A Viewer's Perspective

Anita Cloete

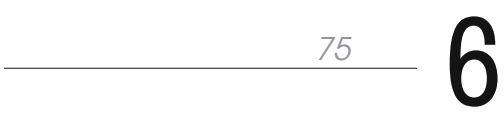

Nathan Chiroma

The Socialising Power of Popular

Culture: Superman and the Formation of Masculinity during Adolescence

$93 \quad 7 \begin{aligned} & \text { Culture: Superman } \\ & \text { Masculinity during } \\ & \text { Nathania Hendriks }\end{aligned}$

777 The Pope's Favourite: Babette's Feast

in Theological Perspective

Hans Geybels 


\section{acknowledgements}

I would like to acknowledge the National Research Foundation (NRF) and the Oppenheimer Memorial Trust (OMT) for their financial assistance that enabled me to travel and stay abroad for an extensive period during 2018. During my stay in Uppsala, Leuven in Belgium and Copenhagen I could network with several scholars that share my research interest on the intersection of media and religion. Some of these scholars I met during these encounters are collaborators in this book project. I would also like to thank Stellenbosch University for financial assistance towards the publication cost of the book. It was a great pleasure to work with the collaborators in this project. I do appreciate their work ethic and interesting contributions. The idea for this book came from my research that focused for the past five years on the intersection between religion and media. During this period I identified possible partners and was pleasantly surprise when I send the invitation to them to be part of this project, all of them immediately agreed. Due to their outstanding cooperation we managed to complete the project within a year. 


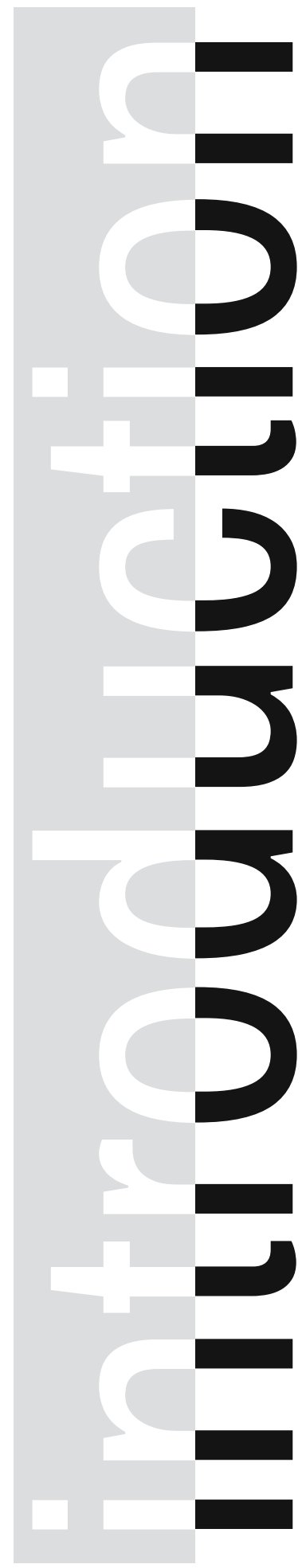


The aim of this introduction is to clarify central concepts as reflected in the title of this book and provide a framework to understand the discussion on the interplay between the different aspects. Therefore, a short description of each concept is offered, followed by a short reflection on the scope of the book.

\section{Religion}

Religion consists of different dimensions and can best be described as multidimensional. Therefore, I do not claim definitions presented here will offer a complete understanding of religion, it will rather emphasise the complexity of defining religion. Religion is often understood by people based on their experience of a particular religion. It is therefore important to register that, although academic definitions exist, people construct their own understanding of religion influenced by their immediate, but also the global context. Religion is closely linked with identity and context and can be understood as a social construct that changes as social context changes. The relationship with that which people regard as sacred, is also of importance in the understanding of religion. Lynch (2005:270) distinguishes between two views of religion, namely the functional view and the substantive view. The functional view refers to certain functions that religion fulfills in people's lives, while the substantive view focuses on certain elements of religion, like the supernatural, religious roles like priests and rituals and sacred spaces like churches.

Mahan (2014) gives a broad definition of religion, but identifies specific elements, guarding against the possibility that everything is religion. Referring to the work of Geertz (1973) and Orsi (2004), he defines religion as "beliefs and rituals performed by people as an expression of such beliefs". Singleton (2014:9) summarises the elements of religion as "myths, guidelines for living, experience and transcendence". These different elements perform certain functions in the lives of people, like creating a community, motivating them and linking their everyday living with the transcendent reality. Campbell (2007) stresses authority as an "integral aspect of religion as displayed through hierarchical religious roles, religious structures, ideology and religious texts".

Lived religion is another term that is employed to describe activities that people participate in that are not overtly religious, but could have religious and moral significance for people (Cloete, 2017). Ganzevoort and Roeland (2014:93) emphasise an important aspect of lived religion, namely "that it focuses on what people do, rather than on an official religion". In other words it is characterised by a turn away from institutions and texts to everyday living. Lived religion focuses more on what the individual regards as meaningful experiences and expressions, and less on the prescribed content and practices of traditional institutionalised religion. 
Pete Ward (2017:55) also regards lived religion as an important new development in the field of practical theology, because it focuses on the actions of people. He stresses the fluidness of lived religion by describing it as on the move, focusing on ordinary people's actions in their everyday lives. The idea of the fluidness of lived religion is expanded by describing it as hybrid and incoherent in relation to structured and institutional religion. This kind of expression of religion takes place within and through culture and encapsulates the embodied experiences of people in contrast to the cognitive or doctrinal orientation of traditional institutionalised religion (Ward, 2017:57-58). Lived religion expands the understanding of religion and points to a more individualised form of religion that is experienced outside traditional institutionalised forms of religion.

Religion also provides a framework that assists people to make meaning of and in their life. Although religion as relation to the sacred or transcendent and how it provides a framework for meaning-making differs between individuals, religion has a significant impact on the lives of people. In this sense religion can be understood as a philosophical orientation that informs and affects people's understanding of the world (world view) and how to engage with existential questions like how to cope with suffering and tragedy (Park, 2005:711).

I found the broad definition of religion as proposed by Woodhead (2010) most fitting for understanding religion for this work. She describes religion as culture, including belief, meaning-making, values, tradition and memory. This book engage with several elements of religion in relation to the media namely religious text, meaning making, transcendence, moral guidance, belief, culture ,practice and coping with life. It start with religion as sacred text and film, moving to the value of film for religious education, followed by a focus on how the act of watching film creates an opportunity for meaning-making and engagement with values and provides a discussion plafform in youth ministry. The last chapters focus on specific films, including a chapter commenting on an aspect of a film that seems to perpetuate existing dominant and oppressive discourses, whilst the last chapter shares insight on the theological value of film.

\section{Media}

Media is not a modern phenomenon, because media has been there for as long as people have been communicating. I need to stress, however, that new ways of communicating are developing at a much faster pace today. Therefore, it is important that we not only pay attention to the technical affordances of the media, but also to what people do with media. According to Couldry and Hepp (2017:32), media means, "Technologically based media of communication 
which institutionalized communication". The mediatisation theory as postulated by Hjarvard (2008) implies that the media is a powerful medium that not only communicates religious messages, be it explicit or implicit, but also acts as an agent for religious change. The media has also developed into an institution with its own logic. Couldry and Hepp (2017:15) describes mediatisation as the deep, consistent and self-enforcing role of media in mediated communication today. The increased presence of media and how it constructs the social world through its communicative affordances is, however, not the role of one media form. Instead, media operates in clusters of different media forms that mutually support each other. Film as medium can create religious experience and present religious messages in environments other than religious institutions, providing individuals with an opportunity to construct meaning from the content and experience of film.

\section{Interplay between Religion and Media}

Media uses religion in different ways, as in film, while religion also uses media to accomplish its own mission. Media and religion as two cultural and social institutions are interdependent because communication is a core aspect and activity of both. To understand religion, you need to understand the media, as it has become one of the main domains that presents religion on different platforms. Stout (2012:2) identifies at least two characteristics of the relationship between the media and religion, namely that organised religion is increasingly found in media like films, and elements of religion like ritual and community are experienced through the media. He concludes that media can therefore not be viewed as secular and understanding religion and religiosity can help us understand media.

It is therefore better not to see the media and religion as two distinct phenomena, but to rather focus on the interface between the two influencing each other in numerous ways. Hoover (2003:10) is also of the opinion that religion and the media are coming together in the lived lives and practices of people. Audience reception of film is such a secular, everyday activity, that has religious significance for people as a form of lived religion, defined earlier. What people do in their everyday lives that can have religious significance, confirms the need to focus on the convergence of religion and media sharing the same space, instead of studying them as separate phenomena or institutions. Since the relationship between religion and media can be described as reciprocal, a better understanding of the media can assist us in understanding what religion means today, and the other way around. It is therefore important to take note of how religion is portrayed in the media, because the media is a primary source of what people know about religion (Stout, 2012:1). The term "interplay" emphasises the constant interaction between religion and the media and the effect of this interaction on each other as cultural institutions. 


\section{Youth}

There is not just one way of describing or understanding youth. The complexity of defining youth is well illustrated in the work of France (2007), who offers different perspectives on youth as social category. The functionalist theory, for instance, understands youth as an institution in society with certain roles and purposes in which age is of importance (France, 2007:34), whilst youth can also be understood as a way of living in a specific time and context as postulated by the generational theory (France, 2007:42). With that in mind, the focus on youth is an important one in this book. Several chapters narrate not only how especially young people consume film, but that it has educational and, more importantly, religious significance for them. Although the age aspect of youth is used to focus the empirical work, youth is not understood exclusively as people of a certain age. The focus on youth, as a unit of analysis, was not a random choice, but rather intentional, because young people grow up in a digital world, characterised by the pervasive presence of media. Therefore, young people across the globe are often the key users of technology and consumers of media forms like film, video games, etc. Often film stars are heroes and role models for young people, demonstrating the power and impact that these media forms have on their worldview and identity formation.

\section{Scope of the Book}

This book presents interdisciplinary reflections on the interplay between religion and the media in general and film and religion in particular. Film is often viewed as a secular product and so the act of watching film is seldom related to religion, representing the sacred. Today the relationship between the media and religion is almost obvious, yet complex. This intersection between the media and religion, resulting in an almost interdependent relationship, is the focus of the book. Media, however, is a broad term that does not present a single phenomenon, and therefore one form of media is singled out in this book, namely film.

The understanding of film in this book is not limited to a product consisting of text, sound and images, but also the experience created in the viewer by all these elements. Therefore, an important aspect of this work is the value viewers ascribe to film as a source of meaning-making. Studies often focus on theoretical reflection on the content of film, in other words an analysis of film as a particular text. There are, for instance, several books on the Bible and film, reflecting on how the Bible or religion is presented by film. This book, however, not only entails theoretical reflection, but substantiates such reflection with empirical work with especially young people. The words film and movies are used interchangeably in this volume. 
Although the religious and educational value of film is underscored in this work, it is always done with the understanding that the media does not have a linear affect. Subsequently, the complexity of the media and in this case, film, is demonstrated in the different chapters. This book portrays the media as an agent of cultural and religious change, and therefore underscores the necessity of critical, contextual and interdisciplinary reflection on the interplay between the media and religion.

Although engagement with media platforms is not overtly religious activities, it will become evident through this book that these online spaces can create religious experience that facilitates the complex process of meaning-making. Identity formation is a primary process in the life of young people. It is not only a psychological process, but also a spiritual one in which existential questions about life and how it should be lived, are essential. Research in this book indicates that young people not only associate with the stories told by film, but also integrate and reread their life stories through these stories, as they inspire them to become the people they wish to be. At the same time, findings indicate that film often confirms and reinforces dominant and oppressive discourses and practices that could be harmful, that need to be exposed and criticised.

The fact that participants are from different countries, universities, and disciplines, contributes to the richness of the discussions and theoretical frameworks presented. I hope that the interdisciplinary nature of the work makes it accessible for different disciplines like theology, and religious media, cultural and youth studies. A concerted effort was made to invite contributions not only from established researchers, but to specifically include younger academics focusing on race and gender diversity.

Although the work does not promise a focus on religions, the strong focus on Christianity can be viewed as a limitation.

\section{Outline of Chapters}

Chapter 1 deals with the relationship between film and religion from a biblical perspective. The reflection takes place against the background of film as cultural shaper and reference point for the norms, values and aspirations of society. The central argument of the chapter centres around the movement or change with respect to the study of films from a biblical perspective, called the bidirectional hermeneutical flow between the Bible and film. Bidirectional hermeneutics not only focuses on the fact that movies have biblical notions and motifs, but also acknowledges the contributions of films to make sense of the Bible. The engagement of movies with the Bible therefore enriches and challenges existing biblical interpretive patterns 
and content. Reference is made to several movies that illustrate the argument for bidirectional hermeneutics. The chapter also points out the implications of the democratisation of biblical interpretation, which was restricted to biblical scholars in the past.

Chapter 2 unpacks the value of film for faith education by focusing on the importance of stories as an integral part of film. This chapter understands faith education not only as the sharing of information, but also as equipping children and young people with interpretive and didactic resources. It is argued that to empower youth with these skills, educators should take the media seriously as a socialising agent with a significant influence on how worldviews are formed and on meaning-making today. Therefore, a multi-level approach to film as a source for holistic faith education is suggested. The chapter also discusses the different elements of worldview and adds a theological element that broadens the understanding of worldview.

Chapter 3 extends the conversation started in chapter 2 by demonstrating how the creative elements of media literacy could be utilised for holistic religious education. The chapter reports on an empirical study in which three elements of media literature were used, namely stories, videography and photography, to facilitate religious education. Participatory youth culture is one of the motivations behind the method, which postulates that young people are not only consumers of media, but also producers thereof. This learning process provides an opportunity for students to reflect on their own life stories and identities in a creative way that opens up possibilities for them to explore aspects of transcendence and meaning-making that are vital to their spiritual and faith formation.

The model presented in chapter 4 deconstructs the complex process of meaningmaking while watching films. This model describes a process called "thick viewing", because there are layers that viewers engage with when watching film, including the combination of affect and cognition, as well as a combination of intra-text and extra-text critique. A schematic illustration of meaning-making is presented, demonstrating the processes of meaning-making. This model is informed by an example of empirical work from a project that focused on spectator engagement in film.

Chapter 5 builds on the theoretical reflection of chapter 4 by focusing on the religious function of film from a viewer's perspective. Audience reception is therefore central to this chapter, which attempts to figure out what is the religious value of film as expressed by viewers. In depth interviews were conducted with young people and one of the significant findings was that it is not religious films that are their favourites, but rather films with no explicit religious theme or focus. Personal stories are the 
most important lens used to engage with film and construct meaning. It became evident that the act of watching film is an important everyday activity in the lives of young people, not only for recreational purposes, but that it has an impact on how they live their lives. Engagement with film assists them to navigate difficulties they experience, while their contexts and especially religious backgrounds play an important role in the interpretation process.

Chapter 6 engages with a similar question to that addressed in the previous chapter by exploring the use of film to create a platform for discussion in youth ministry. Findings gathered from focus groups consisting of young people and youth leaders indicate that film could be utilised to facilitate fruitful discussions on personal and social issues. The chapter reports on the educational value of film as reported by youth and youth leaders. It is interesting to note that both youth and youth pastors acknowledge the educational value of film, as it addresses everyday issues that viewers can relate to and, more importantly, strive for.

In chapter 7 the focus shifts to the socialising power of film with specific reference to the formation of masculinity during adolescence. The discussion of film is plotted within the framework of popular culture, focusing on Superman as one of the favourite characters of many young people. The power of technological advancement is confirmed by how this comic book character remains relevant, as it is now also screened at cinemas. Although it is acknowledged that Superman means different things to different people, the chapter zooms in on the presentation of hegemonic masculinity as a dominant culture and religious view of being a man. The author explains that such dominant discourses and social constructions are often very subtle in films, but could have serious consequences for the healthy development of masculinity, as it could marginalise those who do not fit this norm. A plea is made for alternative, life-giving and more diverse social constructions of masculinity that include, and do not exclude and marginalise.

Chapter 8 presents a theological reflection on the film Babette's Feast, initially released in 1987. Although the film provoked a plethora of opinions and interpretations, the theological significance of the film centres on the act of the refugee Babette, who spent all she had on a meal commemorating the death of her family. The author explains why the film is also the Pope's favourite, after which he gives his own understanding of the theological significance of the film. Again, this is not an explicitly religious film, but it still provokes religious and theological questions that lead to theological reflection and responses. 


\section{Bibliography}

Campbell, H. 2007. Who's got the power?

Religious authority and the internet. Journal of computer mediated communication, 12:1043-1062. https://doi.org/10.1111/ j. 1083-6101.2007.00362.x

Cloete, A. 2017. Film as medium for meaning-making: A practical theological reflection. HTS Theological studies, 73(4): 1-6. https://doi.org/10.4102/hts.v73i4.4753

Couldry, N. \& Hepp, A. 2017. The mediated construction of reality. Cambridge: Polity Press.

France, A. 2007. Understanding Youth in Late Modernity. Berkshire: Open University Press.

Ganzevoort, R.R. \& Roeland, J.H. 2014. Lived Religion: The praxis of practical theology. International Journal of Practical Theology, 18(1):91-101. https://doi.org/10.1515/ijpt2014-0007

Hjarvard, S. 2008. The mediatisation of religion: A theory of media as agents of religious change. Northern Light, 6:9-26. https://doi.org/10.1386/nl.6.1.9_1

Hoover, S.M. 2003. Religion, Media and Identity: Theory and method in audience research on religion and media. In: J. Mitchell \& S. Marriage, Mediated Religion: Conversations in media religion and culture. London: T\&T Clark. pp.9-19.
Lynch, G. 2005. Understanding theology and popular culture. Victoria: Blackwell Publishing.

Mahan, J.H. 2014. Media, Religion and Culture. London: Routledge. https://doi. org/10.4324/9781315777061

Park, C.L. 2005. Religion as Meaning-making framework in coping with life stress. Journal of Social Issues, 61 (4):707-729.

https://doi.org/10.1111/j.15404560.2005.00428.x

Singleton A. 2014. Religion, culture and society: A global approach. London: Sage. https://doi.org/10.4135/9781473920743

Stout, D.A. 2012. Media and Religion: Foundations of and emerging field. Abingdon: Routledge.

Ward, P. 2017. Introducing Practical Theology: Mission, Ministry and the life of the church. Michigan: Baker Academic.

Woodhead, L. 2010. Five concepts of religion. International Review of Sociology, 21 (1):121-143. https://doi.org/10.1080/0390 6701.2011 .544192 


\section{Introduction: Modern Culture, Bible and Film}

Movies and spirituality are today often found in close proximity to each other and the connections between the Bible and films are indicative of this relationship.' Our focus here are on the intersections between the Bible and popular movies, which have started to move beyond portrayals of biblical stories or characters only, although such movies are still produced, as for example the 2018 movie, Paul, Apostle of Christ. Today's popular movies relate in one way or another to the Bible and/or biblical themes, in different ways, and some more direct than others. Whereas past investigations almost exclusively explored how movies take up and explore biblical themes, the contribution of movies to biblical interpretation or reverse hermeneutical movement from film to Bible, has often been neglected. Considering both, bidirectional hermeneutical flows allows one to explore the value of biblical notions for making sense of movies, while appreciating how movies contribute to biblical interpretation introduces a dynamic, but complex set of implications. The argument is illustrated with reference to some recent films on the popular circuit.

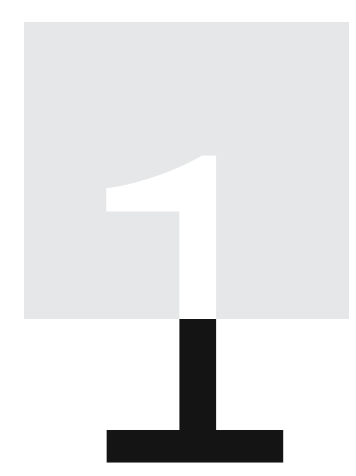

\section{SCRIPTURING MOVIES AND FILMING SCRIPTURE}

Bidirectional

Hermeneutics

Jeremy Punt

1 Some authors use "film" for those forms of the medium which pursues appreciation at a higher level for its artistic nature, and "movies" when entertainment value and commercial success are primary. This distinction is unhelpful for my purposes here, as it perhaps is generally, as well also in light of Browne's reminder in his deliberate misquote of playwright Noël Coward, "Even at its most 'commercial' one must not dismiss ... the potency of cheap movies" (Browne, 1997:10). I thus use film(s) and movies interchangeably. 
The interrelationship between culture, religion and theology is often both more pronounced and at the same time, more intricate, than what superficial comparisons and correspondences allow. In a brief, but engaging introduction to a book on this theme, and notwithstanding a self-declared USA-biased perspective, Cobb (2005:1-25) traces some major developments in the relationship between culture, theology and religion, stressing an important, vital shift. In the earlier history of the world, religious and theological notions were explicitly present in cultural representation, given people's perceptions about the interrelatedness if not integratedness of life. Since the Renaissance and Enlightenment, however, the gradual differentiation and even separation of cultural value spheres such as religion, family, art, science, politics and economy, meant that people could claim that their primary identity derives from any one of these spheres. So, unlike popular sentiment that would have it at times, it means that the contemporary links between Bible and film, or movies, have been neither natural nor normal. However, the ongoing, lingering effects, as well as a rediscovery of the religious, the theological and also the biblical in popular media - even then these elements are not always recognisable as such - ask for greater awareness in tracing such possible links and more reflection on the hermeneutics involved.

In the area of biblical studies, investigations of Bible and film are indicative of the growing interest to account for the wider reach of the Bible. ${ }^{2}$ The reach and extent of the Bible's influence in society over many centuries has been vast, even if fluctuating, in different eras and localities, and even if such influence was neither always acknowledged nor necessarily accounted for. ${ }^{3}$ Moreover, the growth in cultural studies investigating the Bible, is an acknowledgement of its broad social impact, as well as of the democratisation of the Bible. This is characterised by the inclusion of other voices in society in the interpretation of the Bible, together with the ongoing development of what can be called "polyphonic hermeneutics" (Glancy, 1998:461).

2 For an excellent account of the Bible and film, in the sense of how bibles feature in different ways (including as commodity and character) in a great variety of movies, see Moses (2004:399-422). My focus here is more narrowly on the link between biblical notions and film, and the bidirectional flow between the two, i.e. the reciprocity between movies taking up and exploring biblical themes, and the contribution of movies to biblical interpretation, from film to Bible.

3 However, hermeneutical shifts such as Fernando F. Segovia's advocacy for and theorisation of "intercultural criticism" in biblical hermeneutics emphasises the constructed nature of the text as much as textual meaning as the result of an interactive process between reader and text, but never in a neutral way since the text is "filtered by and through the reader" (Segovia,1995c:296, cf 1995a:28-31; 1995b:7-17). 
The contemporary popularity of film is related to its ability to convey shared values and concerns and to address and even challenge the collective memory. "Popular culture (novels, film, music, journalism, sports, TV, fashion and advertising) encompasses the preferred art forms of our age, drawing in many of our most creative minds to produce it. In the culture at large it has become, for most, the primary instrument for forging personal identity and probing the cosmos for meaning." (Cobb, 2005:291-292) Movies reflect the meaningful symbols and values of society, and yet, at the same time, also shape them. In fact, some scholars reckon that in our era, popular media has become the most significant element in shaping human consciousness and reshaping language (Kysar, 2005:223). Movies have become a reference point in terms of norms and values, worldview and ideology, convictions and aspirations. ${ }^{4} \mathrm{~A}$ host of recent publications on film and religion, film and theology, and film and the Bible attest to both the growing involvement of film in people's lives, as well as scholarly interest in these connections. ${ }^{5}$ Against this background, this brief reflection focuses its attention both on how the Bible features in film, and how film becomes a vehicle for how people reads and reaches back (in)to the Bible, that is, for the bidirectional hermeneutical flows between Bible and film.

\section{Hollywood's Mixed Feelings for the Bible}

In large parts of the world, the Bible is part of a cultural legacy (Brenner, 2000:7-12; Sugirtharajah, 2003:81), and feeds into, among others, the film and religion or theology or spirituality relationship, which today is often claimed as one of closeness. ${ }^{6}$ In fact, for many people the traditional division between popular media

4 Moreover, since all films are located in culture, and since all culture is ideological, films are inevitably entangled in ideology. This is true of all kinds of films, and of films of all parts of the world: "in relation to audience, the central dynamic is the relationship of film to culture; or more specifically between cinema and audience/reader and text [sc the film]." (Browne, 1997:11)

5 Recent overviews and assemblages of studies on these and related topics, would include the following: on film and religion, see e.g. Lindvall (2004:3-40; 2005:3-44), Moses (2004:399-422); Walsh, Staley and Reinhardt (2013); on film and theology, see e.g. Marsh and Ortiz (1997); and, on film and the Bible see e.g. Burnette-Bletsch (2016), Vander Stichele and Copier (2016). See also below in list of works cited for a still wider range of related studies.

6 The well-known director, Martin Scorcese is on record as saying: "When I was a little younger ... I wanted to be a priest. However, I soon realised that my real vocation, my real calling, was the movies. I don't really see a conflict between the church and the movies, the sacred and the profane. Obviously, there are major differences. But I can also see great similarities between a church and movie-house. Both are places to come together and share a common experience." (Marsh \& Ortiz, 1997: title page) 
like movies and religious convictions and dispositions has all but disappeared. It is no longer uncommon to find religion-oriented guides on how to talk about movies or on movie-watching as spiritual exercise (e.g. Davidson, 2017), on notions such as reel spirituality (e.g. Johnston, 2000) or screening Scripture (e.g. Aichele \& Walsh, 2002), and some authors even go so far to postulate film as religion (e.g. Lyden, 2003; Marsh, 2004). Connections between the Bible and movies, and appreciation for the connections, explain why movies have moved beyond biblical films which retell biblical stories, even though such movies remain and still attract audiences.

However, the earlier genre of respectful films on the Bible in the style of an early exponent like The Greatest Story Ever Told has become uncommon today, for different reasons. References and prejudices of contemporary audiences, as well as major production houses' reluctance to engage serious religious subjects (Cieply, 2014), have nevertheless not meant that serious films about religion are no longer produced. Films on Jesus Christ and his legacy include for example The Last Temptation of Christ, Jesus Christ Superstar, Jésus de Montréal ("Jesus of Montreal"), while the contextual Son of Man and recent mainline Son of God have recently been released, as were other Bible-related movies such as Noah with Russell Crowe.?

Within this genre of Bible movies, it is very typical to find that movies constitute composite portrayals of characters and events. This is particularly noticeable in Jesus-movies where the different accounts of the Gospels, and sometimes others too, ${ }^{8}$ are joined into a movie plot for a specific purpose and audience. As for cinematic portrayals of Jesus Christ, Loughlin reminds us that Jesus films are not the same as Christ films, and that a movie such as Passion of the Christ fits the latter category better. "Gibson's film stands in a long line of what have become known as Jesus films, films about the life of the Nazarene. These are often contrasted with Christ films, movies where certain Christic motifs inform characterisation, theme and/or plot. And though Gibson's film is about the historical Jesus, it might more reasonably be described as a Christ film, since unlike most of its predecessors it does not doubt that Jesus is the Christ, and Christ as the incarnate second person of the Trinity". (Loughlin, 2012:124)

7 Related genres are Bible-related series such as Downey and Burnett's mini-series, The Bible, or various children's series based on the Bible, but there are no room for this discussion here. Movies where the relationship to the Bible, e.g. Pompeii, billed as a disaster-adventure film, are also not considered here.

8 In Gibson's Passion of the Christ, for example, the (anti-Semitic) visions of the Roman Catholic nun Anne Catherine Emmerich (1774-1824) as captured in her The Dolorous Passion of Our Lord Jesus Christ played a central role in putting together the events surrounding the death of Jesus, and served as a hermeneutical frame for the passion in the gospel according to Matthew. 
The 2018-release Paul, Apostle of Christ is a good example of Bible-based movies. It is a portrayal of part of Paul's imprisonment in the Mamertine prison in Rome before his eventually execution during the time of Caesar Nero. The plot, again, rests on a composite of elements taken from Paul's letters, the Acts of the Apostles and Christian tradition and reception history over time. The movie portrays the imagined visiting of Paul in prison by the apostle Luke to enable him to put the Acts of the Apostles together. Mauritius, the warden's initial resistance against Paul gradually changes into a changed attitude, especially after the efforts of Paul, Luke and the other Jesus followers help to bring about the recovery of Mauritius's ill daughter. Such composite portrayals often incorporate elements which are not part of the same biblical narrative, notwithstanding claims to the contrary (McLean, 2018). For the largest part, audiences will not find such plotlines problematic, since the erstwhile basic working knowledge of biblical narratives like the exemplary persons in the history of the church, rituals and symbols associated with the Bible and church, or even the essentials of the church creeds, can no longer be assumed. Increasingly, then, both in the sense of larger numbers of people and also across a broader, global spectrum, popular culture and media determine the conceptions of the world of whole generations (Cobb, 2005:7; Moses, 2004:415). ${ }^{9}$

The influential role of popular media is not to be denied, but so too neither the presence of biblical motifs, elements, characters or themes in popular movies outside the biblical movies genre. Apart from film scholars and theologians, biblical scholars like Robert Jewett (1999) and Larry Kreitzer (1999) have shown upon the widespread, subliminal presence of biblical matter in movies. Two blockbuster movies, both of which were major box-office successes and introduced new takes on science-fictions movies, each in its own right, Blade Runner and The Matrix, are replete with explicit and surreptitious biblical notions, even if they both are far removed from the genre of biblical film. In Blade Runner the parable of the Prodigal Son (Luke 15:11-32) forms a prominent and interesting biblical intertext that lingers throughout the movie. ${ }^{10}$ Names and themes in The Matrix are suggestive of biblical or Bible-related elements, presented in twenty-first century format. Cypher

9 "Television, movies, a multitude of genres of music, amusement parks, fast food franchises, action heroes, Dr Seuss, Disney, DreamWorks, comic books, advertising, soundtracks, mail order catalogues, video games, contemporary fiction, sports, celebrities, journalism, wall art and science fiction have been the primary sources of the myths, parables, iconographies, hagiographies, devils and heroes that orient them in life. From this plethora of material, whole generations now attempt through bricolage to invest life with meaning and find a justification for their lives." (Cobb, 2005:7)

10 In Blade Runner the almost apocalyptic scenario and religious specific references such as the "God of mechanics" who "controls access to heaven" also suggest a lingering, subtle interest in exploring spiritual and religious aspects of human life and society in the world of celluloid science fiction. 
invokes Lucifer, the one who eventually betrays $\mathrm{Neo}$ and his group's mission, and who identifies himself as "messenger" reminiscent of the portrayal of Satan in Job (HB). It is in particular the focus on the messianic "One", called Neo, with his initial messianic self-denials which contrasts with the hope and testimony of his followers that invoke Gospel analogies in the NT (see Punt, 2003, 2007).

The value of considering intertextual links between biblical literature and the popular media is clear, but complicated and multifaceted. Biblical scholarship often points to how such links underline the Bible's reception history and, indeed, the lingering influence of both the Bible and its interpretive legacy in an increasingly secular world. ${ }^{11}$ From a cultural studies perspective on biblical materials, in particular, the ongoing biblical intertextuality in film attests to the level and depth of the penetration of the Bible in the modern world, and allows for unpacking the often assumed, and purportedly common-sense aspects of modern society. ${ }^{12}$ For the Bible, apart from other roles it occupies, is of course also a cultural document and part of the cultural legacy of large parts of the world. ${ }^{13}$ Throughout history and still in the current context, and with the ongoing jostling for hermeneutical power between confessional and non-confessional readings, ${ }^{14}$ the Bible's use in popular media like movies stimulate investigations into the reversal of the hermeneutical flow between, or better still, the bidirectional hermeneutics of the Bible in film.

\section{Biblical Interpretation Gaining from Movies}

The film industry has not only found the Bible to provide plot-lines and intrigues fit for movies, but movies have often managed to return the favour. Films contribute to

11 But this has to be qualified, since although institutional religion is on the decline and in some areas heavily and increasingly so, a worldwide increase in matters related to spirituality is recorded. "The functionalist focuses on institutional religion had failed to notice that, while institutional religion was declining, religion as movements and as cultural practice was growing in importance." (White, 2004:197)

12 Of the many different factors playing a role in how the Bible function in film, denominational specificity also play a role: "Films in Protestant settings, especially those about charismatic preachers in the Bible Belt, use the Bible as cultural object far more dramatically (even histrionically) than films set among Catholics and Jews."

(Moses, 2004:417)

13 The role of religion needs renewed attention, too: "The functionalist focuses on institutional religion has failed to notice that, while institutional religion was declining, religion as movements and as cultural practice was growing in importance." (White, 2004:197)

14 What Sugirtharajah (2003:47) argues for East Asian retellings of the Prodigal Son, applies across a broader spectrum: "Unlooped from the binds of Christian interpretative traditions, biblical narratives will keep on offering new complexities and dimensions to the story." 
the interpretation of the Bible as much as the Bible is an important intertext in many films. ${ }^{15}$ It is often the multicultural diversity of film audiences which lead to filmmakers compensating for the lack of a common and predictable canonical subtext. Biblical narratives are completed or augmented in ways that amount to functional overdeterminations and where the symbolic and iconographic characteristics of the film genre in which the story is embedded determine the shades of meaning rather than the original, biblical content (Moses, 2004:415). As was argued in greater details elsewhere, even popular, blockbuster movies like The Matrix or Blade Runner, have no intent to portray or even be associated with biblical narratives or themes, yet nevertheless often enrich those biblical themes or narratives which these movies enlist and exploit (Punt, 2003, 2007). Popular movies often reverse the hermeneutical flow, enriching biblical interpretation by presenting alternative ways of understanding its narratives, plots and characters - in this way a bidirectional hermeneutics is established.

The connection between the Bible and film comprises more than movies portraying biblical stories or characters, although these movies seem to remain popular among certain audiences. The wide appeal of film is characteristic of popular culture that engages people on a wide spectrum, including on the more existential issues such as life and death. ${ }^{16}$ Questions about life and death from time to time include questions about God or the supernatural, and often permeate even films not expressly pursuing a connection with religion or the Bible (Bergesen \& Greeley, 2000: 17-19). ${ }^{17}$ Film directors typically have a strong influence on how their movies explore links with religion and the Bible. Loughlin (2012:122) sees the protagonists in Scorsese's movies not so much as Christ-figures in the sense of replicating the Nazarene's life in new context, but rather as "Christ-identified-figures, and identified with his suffering as in itself salvation; a purifying of the soul through the spilling of blood". Past investigations which almost exclusively explored how movies take up

15 Honouring bidirectional hermeneutical flows implies, among other things, a break with that part of conventional biblical scholarship that holds onto objective neutrality in interpretative processes and an impoverished semantic position that a text has only one meaning. Interpretation is of course never neutral and never exegesis in the absolute sense of the word, as if the opposite is both exegesis and abhorrent. Different levels and forms of eisegesis are all that exist, situated in ideology. See further Punt (2016a:853-855; 2016b:289-313).

16 Generalising, Morris (2013) thinks that NT films play "to the basic humanity in us all - perhaps in the simple hope that it will make us a little more understanding, tolerant and more emotionally enlightened as we move through this thing called life".

17 Bergesen and Greeley go to great lengths to stress that they are sociologists and not theologians, nor apologists for faith and/or religion, although they profess their denominational faiths (Bergesen \& Greeley, 2000:177). See Miles (1996:xiv) on film's supposed "invidious triviality". 
and explore biblical themes, have all too often overlooked the impact of movies on biblical interpretation. This reverse hermeneutical flow, from movie to Bible, or more properly, bidirectional hermeneutical flows have wide impact and allow for exploring the value of biblical notions for making sense of movies, while appreciating how movies contribute to biblical interpretation.

In terms of hermeneutical bidirectionality, Blade Runner suggests that emotions play a vital role in human existence, together with the anxiety and anguish. This creates liminality and vulnerability, at times this leads to animosity between people, but also attempts to achieve reconciliation. Within this broader setting, the intertextual echoes of the parable of the Prodigal Son in Blade Runner highlight both the inter-relational animosity of the parable, but at the same time show upon vulnerability as both the ground for and means by which animosity is refused and challenged. This movie, building on the acknowledgement and actualisation of vulnerability, also as a means of addressing animosity, challenges the traditional conviction that authority authenticates vulnerability: that the father/creator assumes, or should necessarily assume, accountability. Blade Runner challenges prodigals of Luke as much as those of today to do more than turn around, but to also assume responsibility for their own lives and those of others (Punt, 2007). In this way, Blade Runner picks up, but also advances the interpretation of the Lukan parable, challenging the movie's audience to rethink the prodigal along, but also outside the lines of traditional biblical interpretation.

The Matrix also interacts hermeneutically with biblical themes, evidencing an adaptation of already present religious notions among the film's audiences. The movie becomes a metaphor for humankind reaching beyond itself, in search for a better world, beyond an illusionary reality, foreseen to be mediated by a messiah and a process which will necessarily entail violence. ${ }^{18}$ It provides a fascinating appropriation of biblical themes and allusions, providing a contemporary and non-conformist investigation of biblical material, and in this case, also of the interrelationship between messianic figures, their followers and violence. Of all the biblical elements, actors and scenes, none is as powerful as the complex of ideas around the messiah figure. The movie vividly explores how messiahship is epitomised firmly and primarily by violence, allowing a renewed appreciation for Jesus' cross in the NT, but also for ensuing rituals like baptism with its dying

18 The movie has also given cause to some conspiracy theory authors, such as David Icke (2001), to argue that The Matrix is much more than a movie script, but in fact reflects our reality. The life which we live and think that we live, is but an illusion, while our lives are controlled by an interdimensional, subterranean, reptilian race. For Icke it is then also but a short step towards confirming the illuminati conspiracy, the Rothchild family's control over Israel, and the Holocaust "industry" (à la Finkelstein). 
(and rising) sentiments, and holy communion's body and blood signs. The movie's insistence on the violence inherent to messiahship cauterises the latter against its romanticisation, putting in perspective the development of religious festivals now etched in the violence Jesus and others had to suffer, like Christmas against the backdrop of the slaughter of the infants, or Easter embedded in the passion of Jesus (Punt, 2003:139-155). The Matrix picks up on a familiar theme in the Bible, the link between a messiah figure and violence, but both insists that violence constitutes the messianic and resists a superficial sentimentalising of the messiah.

The appreciation of bidirectional hermeneutics in the Bible and film-intertextualities acknowledges not only that movies take up biblical notions, themes or characters into their plots. Bidirectional hermeneutics also recognises the contribution of movies to making sense of the Bible, and how it allows for renewed engagement with, enrichment of, and challenge to established biblical interpretive patterns and content. Basic to the success of movies is the narrative plot or narrativity, which is the engine which drives the audience during the journey on which the film takes them. Underneath the narrative of the film made up of elements such as plot, causality, time and space, range and flow of information, narrative conventions, characters and their development and so on, is found in the ideology of the film (Browne, 1997:16-17). It seems that when biblical aspects are taken up into the plots of movies, a bidirectional flow is created which in the end contributes not only to movie plots, but also to the (reimagined) interpretation of the Bible. If indeed, as Cobb (2005:7) would have it, that, "The media-world has ... become a new cultural sphere with its own distinctive good and guiding norms, its own protective institutions, its own creeds, laws, monuments, prophets, myths and rituals, and discipline of inquiry (culture studies)", what is the possible impact of bidirectional hermeneutics for the Bible and film intersections?

\section{Dealing with Bidirectional Hermeneutical Flows}

The relationship of the Bible to film, as to art, music and other areas, is an indication of the extent to which the Bible's influence is constantly extended or the broadening out beyond biblical scholars' horizons and interests. Paul Tillich's notion that "while religions depend upon the cultures in which they find themselves for their forms of expression, cultures draw the meaning that they hold for those who inhabit them from an underlying substrate of religious faith" (Cobb, 2005:5), has never been more appropriate in the history of the world than today. The Bible and popular media intersections are also indicative of two other matters. One, the Bible cannot simply be fenced in for the purposes of any specific community, notwithstanding (strong) claims on the Bible or appeals to historical practices, and two, with the 
Bible out in the open, beyond the control of academic and theologians and the church, a process of democratisation of the Bible is underway, not totally unlike what happened since the nineteenth century when the academic study of the Bible wrestled it from the total control exercised over it by clerics (Punt, 2012:44). The bidirectional hermeneutical flows in Bible and film underscores these matters in a profound way.

Bidirectional hermeneutical flows between the Bible and film vary, and may at times, like beauty, of course be in the eyes of the beholders or interpreters. ${ }^{19}$ At any rate, if nothing else, hermeneutics as interpretive venture involves not only the object of interpretation, but also those who act as agents of interpretation, neither of whom can fully control the interpretive process. Like readers with texts, viewers make sense of movies; like texts impacting on their readers, so do movies their audiences. In the ongoing hermeneutical flows between Bible and film, the reverse flow from film to Bible as mooted in the past (e.g. Jewett, 1999; Kreitzer, 1999) underscores that the hermeneutical flows are probably best represented as bidirectional. Rather than perceiving bidirectional hermeneutical flow as a threat to biblical interpretation, Cobb's (2005:6) claim for the relationship between theology and popular culture can be expanded also to Bible and film: "a better understanding of popular culture and its fascinations might assist theology to overcome some of its own prejudices and break through some of its impasses."

The democratisation of the Bible is an important theme in modern society, brought about by an increasing awareness of societal and various other hegemonies and a stronger sense of (the need for) self-actualisation. ${ }^{20}$ But such instances of the democratisation of the Bible are not uncomplicated. So too a bidirectional hermeneutical flow at times can contribute not so much to clarify understanding as it may complicate and even introduce foreign notions, often formed by long interpretive histories, into the text. A case in point is a literary scholar's remark that Passion of the Christ is better categorised as part of the horror genre, and highlights the film's primary allegiance to its own medium and transferring its "theatrics" into

19 Bidirectional hermeneutical flow is only one of a wide range of theoretical justifications for exploring the overt and subliminal interrelationship of Bible and film. Others include: their mythic and ritualistic way of operation; sharing religious functions or settings; dealing with existential questions; transmitting important values; resolving cultural tensions; providing escape; both are cultural artifacts or ideological tools; share in common discourse and content features; and, both are "popular" products (Aichele \& Walsh, 2002:x). See also Browne (1997:9-19).

"We seem conditioned with each rising generation to subvert the dominant paradigm, but then find some novel way to reconcile our rebellion with the enticements to consume." (Cobb, 2005:12) 
the biblical narrative. In the end, "it becomes harder to tell the difference between the believer who meditates on the passion and the person who goes to the cinema for the pleasure of watching torture and death" (Loughlin, 2012:125). At the same, though, such social patterns are also a stark reminder that "a film [is] one voice in a complex social conversation, occurring in a particular historical moment" (Miles, 1996:xiii), and that the democratisation of the Bible through film should not be idealised.

Getting to grips with bidirectional hermeneutical flows are complicated by other factors as well. A primary obstacle is that the flow is never primarily from and to the biblical texts. To a certain extent, the connection between Bible and films has ever really been only about biblical interpretation, or even better, the history of biblical interpretation and film (see also Loughlin, 2012:122-130). ${ }^{21}$ In other words, is the connection often called Bible and film not better worded by reception history of the Bible and film, knowing full well that these very explorations feed also the connection? Another particular challenge in the Bible and film relationship concerns the different media formats of the two spheres. "While objects in the cinema by and large 'are' content, books as objects 'have' content, however generic the content may be" (Moses, 2004:400). Not only are these different genres hermeneutically tapping off one another, each own genre specific aspects are bound to rub off on the other, rendering ambivalent media.

Finally, the relationship between the Bible and film calls for acknowledgement of both the intertextual embeddedness of all parties concerned, as well the triadic nature of comparisons. What J.Z. Smith posits for comparing religions, holds true for comparing Bible and film, too. Comparisons do not only entail the two elements related to one another, but always include an implicit "more than-" or "with respect to"-component, connected most often to the audience or interpreters' interests (Smith, 1990:51). While a film does not permit an infinite number of interpretations, a spectator make sense of it according to his or her education and life-experiences, as well as a repertoire of film conventions and viewing habits (Miles, 1996:10). That is, the relationship between Bible and film include other,

21 In fact, the history of biblical interpretation reflected, and inverted, in film is vast. As Moses (2004:400) puts it, "The Bible comes to the screen charged with centuries of variously transmitted contents, versions, interpretations, and cultural usages ... the Bible on screen can convey a great deal, without abandoning the narrative unfolding of its immediate contact with plot, with characters and with other screen objects. Such contact always already implies all kinds of previous translations and adaptations: translations presupposed by differing cultural codes, different historical moments, differing social contexts; adaptations driven by differing creative agendas, both formal and ideological." 
triadic components which would also have to be accounted for in investigations of bidirectional hermeneutical flows.

\section{Conclusion}

The media world is increasingly becoming both the cultural environment in which people feel at home, but which also serves at the source of their worldviews and which provides them with the resources for making sense of life (Cobb, 2005:72). ${ }^{22}$ It is against this backdrop that one scholar has remarked that the true magic of film is that it does not produce a special effect only, but also a spiritual effect (Loughlin, 2012:130). Much of this is under-theorised, since as much as movies do not always account for their intertextual engagement with biblical notions, the value of cinematographic contributions to biblical interpretation are considered even less. Teasing out such connections between Bible and film in theological deliberation can open up further and even deeper dimensions in the contemporary understanding of biblical texts (e.g. Punt, 2003:139-155). Beyond formal theological study, also in communities of faith, spiritual effects of movies, popular or otherwise, often interact with biblical themes or communicate visually about the Bible, but are also related to bidirectional hermeneutical flows in such interactions. In fact, not only images, but "visual practices matter, because they are part of the fabric of social and religious life" (Heath, 2013:8). The so-called ordinary readers of the Bible are often also those who watch movies, so that alertness to the links between the Bible and movies could enrich cinema-goers experiences, but moreover, allow for the discovery of further, alternative interpretations of biblical texts they are familiar with. In the words of Shohat (2004:23), "the displacement of written text onto a cinematic space ... cannot be appreciated solely in its formal dimension; rather, it must be seen within a larger, millennial movement across philosophical traditions and cultural spaces". Acknowledgement of bidirectional hermeneutical flows provides an accountable platform for analysis and can do justice to both components in exploring the relationship between the Bible and film.

\section{Bibliography}

Aichele, G. \& Walsh, R. 2002. Introduction.

Scripture as Precursor. In: G. Aichele \&

Film. Harrisburg: Trinity Press International.

R. Walsh (eds.), Screening Scripture.

pp. vii-xvi.

Intertextual Connections between Scripture and

22 "It is under the canopy of the media that we imbibe, speculate about and negotiate the meaning of love, friendship, beauty, happiness, truth, hope, pain, grace, luck, work, sacrifice, and death." (Cobb, 2005:72) 
Bergesen, A.J \& Greeley, A.M. 2000. God in the Movies. New Brunswick: Transaction Publishers.

Brenner, A. 2000. Foreword. In: G. Aichele (ed.), Culture, entertainment and the Bible. JSTOT 309. Sheffield: Sheffield Academic Press. pp.7-12. https://doi.org/10.1017/ CB09780511818004.001

Browne, D. 1997. Film, Movies, Meanings. In: C. Marsh \& G. Ortiz (eds.), Explorations in Theology and Film. Movies and Meaning. Oxford: Blackwell. pp.9-19.

Burnette-Bletsch, R (ed.). 2016. The Bible in Motion. A Handbook of the Bible and Its Reception in Film. Handbooks of the Bible and Its Reception (HBR). Berlin/ New York: De Gruyter. p.2. https://doi. org/10.1515/9781614513261

Cieply, M. 2014. Can God make it in Hollywood? New York Times, 22 February. nyti.ms/2Q1 ctTQ

(Accessed 27 February 2014).

Cobb, K. 2005. The Blackwell Guide to Theology and Popular Culture. Blackwell Guides to Theology. Malden: Blackwells. https://doi.org/10.1002/9780470774731

Davidson, E.L. 2017. How to Talk to a Movie. Movie-Watching As a Spiritual Exercise. Reel Spirituality Monograph Series, Vol. 1. Eugene: Cascade.

Glancy, J.A. 1998. House Reading and Field Readings: The Discourse of Slavery and Biblical/ Cultural Studies. In: J.C. Exum \& S.D. Moore (eds.), Biblical Studies/Cultural Studies. The Third Sheffield Colloquium. JSOTSS, Vol.266; Gender, Culture, Theory, Vol.7. Sheffield: Sheffield Academic Press. pp. 460-477.

Heath, J.M.F. 2013. Paul's Visual Piety. The Metamorphosis of the Beholder. Oxford: Oxford Academic Press. https://doi.org/10.1093/ acprof:oso/9780199664146.001.0001 Icke, D. 2001. Who are the children of the Matrix? How and interdimensional race has controlled the world for thousands of years and still does. Wildwood, MO: Bridge of love.
Jewett, R. 1999. Saint Paul returns to the movies. Triumph over shame. Grand Rapids: William B Eerdmans.

Johnston, R.K. 2000. Reel Spirituality. Theology and Film in Dialogue. Engaging Culture. Grand Rapids: Baker Academic.

Kreitzer, L.J. 1999. Pauline Images in Fiction and Film. On Reversing the Hermeneutical Flow. The Biblical Seminar, No.61. Sheffield: Sheffield Academic Press.

Kysar, R. 2005. Voyages with John. Charting the Fourth Gospel. Waco: Baylor University Press.

Lindvall, T. 2004. Religion and Film. Part I: History and Criticism. Communication Research Trends, 23(4):3-44.

Lindvall, T. 2005. Religion and Film. Part II: Theology and Pedagogy. Communication Research Trends, 24(1):3-40.

Loughlin, G. 2012. Bible and Film: Suffering and Special Effects. Modern Believing, 53(2): 122-130. https://doi.org/10.3828/ MB.53.2.122

Lyden, J.C. 2003. Film as Religion: Myths; Morals; and Rituals. New York: New York University Press.

Marsh, C. 2004. Cinema and Sentiment: Film's Challenge to Theology. Milton Keyes: Paternoster.

Marsh, C. \& Ortiz, G (eds.). 1997. Explorations in theology and film. Oxford: Blackwell.

McLean, D.C. 2018. Scripture is "the only source material" for new film about St. Paul. LifeSiteNews. bit.ly/2Ysd3g9 (Accessed 25 August 2018).

Miles, M.R. 1996. Seeing and Believing. Religion and Values in the Movies.

Boston: Beacon.

Morris, R. 2013. The greatest story Hollywood ever told. The story of Christ and the Bible important to film-making pioneers. The Express, 30 March. bit.ly/ 2VjdOq4 (Accessed 3 February 2014). 
Moses, G. 2004. The Bible as Cultural Object(s) in Cinema. In: R. Stam \& A. Raengo (eds.), A Companion to Literature and Film. Blackwell Companions in Cultural Studies, Vol.7. Malden: Blackwell. pp.399-422.https:// doi.org/10.1002/9780470999127.ch24

Punt, J. 2003. Messianic victims or victimized Messiah? Biblical allusion and violence in The Matrix. In: J. Bekkenkamp \& Y. Sherwood (eds.), Sanctified Aggression. Legacies of biblical and post-biblical vocabularies of violence. JSOTSS, Vol.400; Bible in the $21^{\text {st }}$ series, Vol.3. London: T\&T Clark International. pp. 139-155.

Punt, J. 2007. The Prodigal Son and Blade Runner. Fathers and sons, and animosity. Journal of Theology in Southern Africa, 128:86-103.

Punt, J. 2012. Dealing (with) the past and future of Biblical Studies. A New South African perspective. In: R. Boer \& F.F. Segovia (eds.), The Future of the Biblical Past: Envisioning Biblical Studies on a Global Key. Semeia Studies, Vol.66. Atlanta: SBL. pp.29-45. https://doi.org/10.2307/j.ct32c046.7

Punt, J. 2016a. Imperialism in NT films. In: R. Burnette-Bletsch (eds.), The Bible in Motion. A Handbook of the Bible and lts Reception in Film, Part 2. Handbooks of the Bible and Its Reception (HBR). Berlin/ New York: De Gruyter. pp.853-866.https://doi. org/10.1515/9781614513261-061

Punt, J. 2016b. The odds are ever in the empire's favour. Postcolonial subject-positioning in The Hunger Games. In: C. vander Stichele \& L. Copier (eds.), Close Encounters between Bible and Film: An Interdisciplinary Engagement. Semeia Studies. Atlanta: SBL. pp.289-313.

Segovia, F.F. 1995a. "And They Began to Speak in Other Tongues": Competing Modes of Discourse in Contemporary Biblical Criticism. In: F.F. Segovia \& M.A. Tolbert (eds.), Reading from this Place, Vol. 1: Social Location and Biblical Interpretation in the United States. Minneapolis: Fortress. pp. 1-32.

Segovia, F.F. 1995b. Cultural Studies and Contemporary Biblical Criticism: Ideological
Criticism as Mode of Discourse. In: F.F. Segovia \& M.A. Tolbert (eds.), Reading from this Place, Vol.2. Minneapolis: Fortress. pp.1-17.

Segovia, F.F. 1995c. The Text as Other: towards a Hispanic American Hermeneutic. In: D. Smith-Christopher (ed.), Text \& Experience: towards a Cultural Exegesis of the Bible. Biblical Seminar, Vol.35. Sheffield: Sheffield Academic Press. pp. 276-298

Shohat, E. 2004. Sacred Word, Profane Image. Theologies of Adaptation. In: R. Stam \& A. Raengo (eds.), A Companion to Literature and Film. Blackwell Companions in Cultural Studies, Vol.7. Malden: Blackwell. pp.23-45. https://doi.org/10.1002/9780470999127.ch2

Smith, J.Z. 1990. Drudgery Divine: On the Comparison of Early Christianities and the Religions of Late Antiquity. Chicago: University of Chicago Press.

Sugirtharajah, R.S. 2003. Postcolonial Reconfigurations. An Alternative Way of Reading the Bible and Doing Theology. London: SCM.

Vander Stichele, C. \& Copier, L (eds.). 2016. Close Encounters between Bible and Film: An Interdisciplinary Engagement. Semeia Studies. Atlanta: SBL.

Walsh, R.; Staley, J. \& Reinhardt, A (eds.). 2013. Son of Man. Reflections on a 'South African Jesus' movie. Bible in the Modern World, Vol.52. Sheffield: Sheffield Phoenix.

White, R.A. 2004. Major Issues in the Study of Media, Religion and Culture. In: P. Horsfield, M.E. Hess \& A.M. Medrano (eds.), Belief in Media. Cultural Perspectives on Media and Christianity. Aldershot: Ashgate. pp. 197-218. 


\section{Films cited}

Blade Runner. 1982. United States: Warner.

Jesus Christ Superstar. 1973. United

States: Universal.

Jésus de Montréal (Jesus of Montreal). 1989.

Canada: Max Films.

Noah. 2014. United States: Paramount.

Paul, Apostle of Christ. 2018. United

States: Sony.

Pompeii. 2014. United States: TriStar.

Son of God. 2014. United States: 20th

Century Fox.

Son of Man. 2006. South Africa: Spier Films.

The Greatest Story Ever Told. 1965. United

States: George Stevens Productions.

The Last Temptation of Christ. 1988. United

States: Universal.

The Matrix. 1999. United States: Warner. 
The next generation of pastors, teachers, and therapists must not only learn the language of film but also develop the art of interpretation - seeing and hearing what's happening on big (and small) screens.

Detweiler, 2008:29

\section{Introduction}

Storytelling is core to our media-saturated, everyday life, as it has been throughout human history. People need stories in order to make sense of one's world and life. For centuries, folk tradition and official religion were the major providers of such stories. Nowadays, in many parts of the world, "the cinema storytellers have become the new priests" (Johnston, 2006:28). Contemporary cinema plays a key role in exploring existential questions and thereby offers the viewers vital material for their meaning-making processes. Therefore, "[both] the filmmaker and the film-viewer are in the storytelling business" (Johnston, 2006:135). Story reigns supreme in film.

What, then, are the typical messages that we encounter in the film stories? And how does one relate these stories to the overall biblical storyline? This essential, but often neglected task in faith education is at the heart of this chapter. This will be addressed from an action research perspective, with a focus both on movies and television series, and with church and youth ministry as the arenas for faith education. In our setting, the latter term describes Christian education where children and youth are being intentionally equipped with interpretative, didactic, and/or formative resources.

\section{STORY AND \\ MEANING- MAKING}

\author{
A Multilevel \\ Approach to Film in \\ Faith Education
}

Margunn Serigstad Dahle 
It is appropriate to apply an action research perspective in this chapter (See Bennett, Graham, Pattison \& Walton, 2018: 92-94). A multilevel approach to movies and television series, developed through my long-term research in religious education as a reflective process of progressive problem solving, plays an increasingly significant role in my media literacy work. This includes involvement as a practitioner within the global evangelical Lausanne movement, ' where I am seeking to promote new media engagement (See L. Dahle, 2014) practices for faith education within church, youth ministry and family contexts through teaching, writing and consulting. The aim is to contribute to more intentional and effective film engagement within this global community of practice and beyond.

The perspective adopted on film in faith education in this chapter is interdisciplinary, with an emphasis on worldview theory and missiology. As a researcher and practitioner, I am writing from three basic premises:

1. Faith educators in churches and youth ministries should take media platforms and media messages seriously as significant influencers on socialisation and worldview formation.

2. Movies are key examples of such media influencers, with rich communication and with great potential impact on children and youth.

3. Faith educators need a multifaceted, comprehensive approach to movies, which include their functions both as visual storytellers and as influencers in meaning-making.

The chapter has three parts: First, a comprehensive articulation of a multilevel approach to film, documenting my reflective process of progressive problem solving; secondly, a selection of some relevant theological aesthetical reflections on film from evangelical writers, especially from within the Lausanne tradition; and thirdly, a brief outline of how the multilevel approach to film may be integrated into a holistic faith education.

1 For a comprehensive introduction to the Lausanne Movement, see Dahle, Dahle \& Jørgensen, 2014. 


\section{Establishing a Multilevel Approach to Film in Faith Education}

\section{Developing a Multilevel Approach to Movies and Television Series in Faith Education Research}

Movies and television series have increasingly become a focus of academic studies in various disciplines and from a wide variety of theoretical angles. ${ }^{2} \mathrm{My}$ own exploration of visual, fictional stories from the perspective of worldview theory started with an in-depth textual analysis of the highly popular quality teen soap Dawson's Creek. ${ }^{3}$ This study (Dahle, 2002) interacted with a selection of Nordic and Anglo-American theologians, worldview theoreticians, and cultural critics, including John Nome, Axel Smith, Anders Jeffner, Per Magne Aadnanes, Peder Gravem and James W. Sire, in order to develop and apply a toolbox for worldview analysis of and theological engagement with fictional media messages (Dahle, 2002, 2003, 2006).

This interaction with worldview theory resulted in an initial conceptual framework for defining and understanding worldviews. Following Aadnanes (2002) and his 'life view' concept, worldviews may be described both as subjective and objective systems of thought. Whereas the former are close to Gravem's (1996) emphasis on the personal meaning-making process ('life interpretation'), the latter consist of historical traditions and contemporary trends, whether religious or secular. Whereas Aadnanes describes the content as consisting of views on values, humanity and reality, I added faith as a fourth element. ${ }^{4}$ This conceptual framework was also informed by Sire's (1997) early definition of worldview as "a set of presuppositions (assumptions which may be true, partially true or entirely false) which we hold (consciously or subconsciously, consistently or inconsistently) about the basic makeup of our world" (Sire, 1997:16). ${ }^{5}$

The methodological approach (the toolbox'), as set forth and applied to various fictional universes in these earlier contributions, consists of four parts:

1. The first step is to identify key characteristics of the observable praxis in the fictional universe, such as behaviour and conversation, through a focus on plot, character and dialogue of the movie or the television series.

2. Step two is to identify key worldview elements in the observable praxis, such as foundational views of ethical values, humanity, reality and faith.

\footnotetext{
See e.g. The Blackwell Philosophy and Pop Culture Series.

See http://www.sonypictures.com/tv/dawsonscreek/

My inclusion of faith, understood as trust and search for meaning, was influenced by Nome and Smith.

5 See also Gravem, 1996 and Aadnanes, 2002.
} 
3. The third step is to identify recognisable traces of key worldview traditions and trends in the uncovered worldview elements. This implies exploring how the ideas, convictions and beliefs of the fictional universe fit into common and influential ways of making sense of the world.

4. Step four moves from worldview analysis to theological engagement, through an identification of significant points of contact and points of tension in the fictional media messages. This implies comparing and contrasting with central propositions of Christian belief. ${ }^{6}$

Subsequent to these publications, further interaction with key communities of practice (see the next section) and significant developments within worldview theory led to an expansion of the conceptual framework and the methodological approach. ${ }^{7}$ Sire's revised definition (from 2004) was significant in this phase. David K. Naugle's emphasis on the need to include both the intellectual ideas, the spiritual-moral dimensions, and the semiotic signs in a more holistic, conceptual understanding of worldview, was influential on Sire and resulted in a broader and more nuanced definition:

A worldview is a commitment, a fundamental orientation of the heart, that can be expressed as a story or in a set of presuppositions (assumptions which may be true, partially true or entirely false) which we hold (consciously or subconsciously, consistently or inconsistently) about the basic constitution of reality, and that provides the foundations on which we live and more and have our being.

Sire, 2009:20; 2015:141. ${ }^{8}$

The emphasis on 'commitment' and 'a fundamental orientation of the heart', affirmed my inclusion of faith as a foundational worldview element. Furthermore, this understanding of how worldviews often are being grasped as story, not only as rational propositions, is, of course, highly relevant to the worldview analysis of fictional, visual universes and to the process of meaning-making.

6 "The identification of both points of contact and points of tension can be illustrated with reference to the worldview analysis of the television series Dawson's Creek previously referred to. On the one hand, key points of contact identified in this well-known teen soap included a longing for identity, the affirmation of inner qualities as more important than image, the reality of friendships, a longing for an afterlife and questions about who God is (if He exists). On the other hand, among significant points of tension identified in this television series were traces of relativism, subjectivism, individualism, hedonism, secular humanism, naturalism, as well as existentialism." (Dahle, 2006:171)

7 See Dahle, 2015 (in a textbook for journalists) and Dahle \& Skattum, 2010 (a textbook for Christian faith educators, see further below).

8 See also Naugle, 2002 
These insights from worldview theory, combined with (a) further engagement with film theory, (b) experience gained from several analyses of movies and television series, (c) curriculum development on theology and popular culture, and (d) interaction with key communities of practice in youth ministries and Christian high schools, resulted in a Norwegian textbook (2010) on film as a resource for churches and youth ministry in faith education..$^{9}$ The major title, Manus for livet? indicates that movies and television series are offering 'manuscripts for life' for our meaning-making. ${ }^{10}$

Here, the methodological approach outlined above was expanded into a multilevel approach with six engagement phases, with an increased emphasis on the visual, fictional story as emotionally laden and aesthetically complex:

1. The first two phases belong to the preparatory stage and includes an emotional and an aesthetic phase. The first phase takes the initial emotional response to a fictional, visual story seriously, remembering the direct emotional impact of such stories and the resulting need to make space for emotional processing both individually and collectively. The second phase focuses on movies or television series as a visual narrative, taking into account the appropriate artistic forms, conventions and expressions.

2. The next three phases belong to the analytic stage (i.e. textual analysis from the perspective of worldview theory). Phase three is the identification of the observable praxis in the fictional universe, the fourth phase is the identification of worldview elements in the observable praxis, and the fifth phase is the identification of recognizable worldview traditions and trends in the identified worldview elements.

3. The final sixth phase constitutes the follow-up stage, which is where a normative theological perspective is offered, identifying points of contact and points of tension in the fictional universe when compared with central propositions in Christian faith. ${ }^{11}$

The textbook provided an application of this multilevel approach with a thorough analysis of the Swedish movie As It Is In Heaven (2004). This emotionally appealing and intellectually stimulating film was immensely popular in the Nordic countries (and beyond). It was also highly appreciated by most film critics. The film contained many key identifiable references to a spectrum of recognizable worldviews including

9 This textbook was written as part of the national Norwegian faith education reform, primarily as a resource book for the Church of Norway in their cultural and spiritual engagement with $13-20$ year olds. See further http://bit.ly/2Nq7RJb

10 The title Manus for livet? was inspired by Axelson \& Sigurdson, 2006.

11 It should be emphasised, that my multilevel approach was influenced by a long-term dialogue with Tony Watkins, including reading his insightful Focus: The Art and Soul of Cinema (Watkins, 2007). 
Christian faith, secular humanism, postmodernism and pantheism. Using this film as a case illustrates how well suited the multilevel approach is for a nuanced engagement with films in faith education both individually, in groups and in plenary teaching and preaching.

The multilevel approach in six steps outlined above, has proved to be a fruifful analytic framework for textual analysis of popular media stories, both in-depth analyses in the academy and more popular analyses aimed towards direct use in faith education. ${ }^{12}$ In my own research, exploring the role of the Disney Universe in worldview formation has been a recent focus, relating this theme both to faith education in youth ministry (Dahle, 2017) ${ }^{13}$ and to early childhood education at large (Dahle \& Kro, 2018). This analytical framework has also been inspirational for two earlier research contributions, both when exploring the media world of tweens as a missiological challenge (Dahle, 2014) and how some young Somali immigrants in Norway decode and relate to the values of a popular Norwegian television soap (Dahle \& Kro, 2013).

\section{Utilising a Multilevel Approach to Movies and Television Series in Faith Education Praxis}

As a practitioner within the global evangelical Lausanne movement, I have interacted with three partly overlapping circles with communities of practitioners. ${ }^{14}$

The first circle is the immediate Norwegian context, where my role as team and production director of Damaris Norway provides a platform for research-based communication, serving faith communities with training and resources in media literacy, media critique and Christian apologetics. The second circle is the intermediate European context, with the European Leadership Forum as a platform for lectures and workshops on media awareness, analysis and critique. The third circle is the wider global context, with the Lausanne Media Engagement Network as a platform for serving churches in the Global South with media engagement courses and workshops, equipping these churches for media analysis and critique. ${ }^{15}$

\footnotetext{
12 I have been a supervisor for a number of projects in the various categories. The cases include Big Bang Theory, Modern Family, Grey's Anatomy, Moana and Wonder Woman, as well as the popular Norwegian productions Hotel Caesar and Skam.

13 See also http://engagingmedia.info/key-values-and-worldviews-in-the-disney-universe/

14 See further www.damaris.no, www.euroleadership.org/Media_Communicators, http://foclonline.org/users/margunn-dahle-o and www.engagingmedia.info (Accessed 27 August 2018).

15 This includes media engagement workshops in Madagascar, Peru, Uganda, Kenya, Ethiopia and Tanzania.
} 
There are five aspects of this broad media engagement practice from the perspective of action research:

1. Conceptually, this practice illustrates 'the third mission' of higher education institutions, ${ }^{16}$ which also includes private Christian institutions (such as NLA University College) engaging with societal needs and market demands within their own socio-cultural-economic contexts.

2. Strategically, the three 'circles' of Damaris Norway, European Leadership Forum and the Lausanne Media Engagement Network are natural third mission' socio-cultural-economic contexts for the academic programme Communication \& Worldviews at NLA University College.

3. Experientially, many participants in our media engagement workshops (at least in the Global South) express that media awareness (i.e. equipping for media literacy, analysis and critique) is the least known and most needed area and emphasis of our training.

4. Missiologically, the thematic emphasis on media awareness relates to a broad spectrum of key issues for church and youth ministry, including personal discipleship, faith education and evangelism.

5. Practically, there is an urgent global lack of relevant resources for media awareness in many churches and youth ministries.

These aspects constitute a framework for including three examples of how this media engagement activity operates in relation to key communities of practice. The first example is how Damaris Norway is serving private Christian schools at various levels with online resources and on-site seminars. This includes a pilot project in one of the Christian high schools (Lutheran), where the multilevel approach to movies and television series was taught for a number of years and utilised as a popular approach in the students' final projects on film analysis and worldviews. ${ }^{17}$ The second example is Uganda, with three annual workshops (since 2016) in media engagement for ministers, youth workers and schoolteachers working in the diocese of Kampala in Church of Uganda (Anglican). The third example is Ethiopia, where the theological institutions in the Mekane Yesu Church (Lutheran) are requesting media engagement workshops for theological teachers at various

16 "What is the university's third mission? ... The university is not only responsible for qualifying the human capital (education - the first mission) and for producing new knowledge (research - the second mission). Universities must [also] engage with societal needs and market demands by linking the university's activity with its own socio-economic context." https://www.igi-global.com/dictionary/universitys-thirdmission/51708 (Accessed 27 August 2018).

17 The pilot project at Tryggheim High School included seminars for teachers, which resulted in a full integration of this approach in their own curriculum, thus strengthening their faith education. Subsequently, other Christian high schools have also adopted the approach. 
church-owned institutions, as a follow-up of a highly appreciated workshop for their national children and youth department in November 2017. The media awareness themes, with the multilevel approach to visual, fictional stories as a prime example, prove highly relevant both in Uganda and in Ethiopia. Both countries face an increasing plurality of global fictional stories, which is an immense challenge for faith education.

\section{Reflecting on Selected Evangelical Theological Aesthetical Perspectives on Film}

Theological aesthetics is a growing interdisciplinary field "concerned with questions about God and issues in theology in the light of and perceived through sense knowledge (sensation, feeling, imagination), through beauty, and the arts" (Thiessen, 2004:1). The multilevel approach to film, as referred to above, is an attempt to take theological aesthetics seriously in faith education. This includes teaching emerging Christian generations to appreciate movies and television series as expressions of creativity, culture and art, while simultaneously assessing the messages in the fictional stories in terms of their worldview content.

However, traditionally, such a holistic approach to film has not been widely accepted across evangelical contexts. ${ }^{18}$ Many have grown up in church settings where pastors and youth leaders either have rejected film, have been ignorant of film or have lacked proper interest in film. Such attitudes still seem to be prominent in some evangelical circles, whether in the Global North or in the Global South. The opposite challenge is when Christians consider film only as entertainment, with no worldview messages, no influence or no impact whatsoever. This laissez-faire attitude is probably even more widespread globally than the attitudes of rejection and ignorance mentioned above.

Faith education in evangelical churches needs to face both these unhelpful sets of attitudes, by equipping emerging generations to engage with movies and television series through the multilevel approach. This may be enrichened and strengthened through an interaction with leading contemporary evangelical authorities on theological aesthetics and movies, such as Robert $\mathrm{K}$. Johnston and Craig Detweiler. Johnston points out, "that there is a growing realization that movie stories offer diverse perspectives on life that, along with other types of reflection, invite religious dialogue" (Johnston, 2006:15).

18 See e.g. Romanowski, 2007:27-42. 
Craig Detweiler suggests that we need the concept of general revelation for a balanced theological understanding and analysis of movies: "The theological term to describe this phenomenon is general revelation. It suggests that God can speak through anyone or anything at any time." (Detweiler, 2008:30) This is in many ways a radical concept: "The same God who spoke through dreams and visions in the Bible is still communicating through our celluloid dreams - the movies. As the Spirit of God raised up unexpected sources of wisdom during biblical times, so the same creative Spirit is inspiring actors, screenwriters, and directors today." (Detweiler, 2008:29) At the same time, it is important to realise the ambivalence and limits of general revelation as a key concept for engaging movies and moviegoers:

Movies diagnose our problems and posit our futures. But filmmakers have scant ideas about how to bridge the gap between our dreams and our realities. General revelation tells us plenty about how we live, what we do to each other, and what constitutes the human experience. Intimations of the divine, rumors of a golden past, and hope for a bright tomorrow are laced throughout contemporary films. But general revelation cannot save us. The films we have surveyed offer glimpses of sacrifice and models of redemption, but they lack the salvation found in Christ alone. Can we connect what we have seen on-screen with what has been revealed to us by our Creator God? Can our experience of the broken world meet the suffering and risen Son of God? Can the Spirit lift us out of the dark into the place we long to go?

Detweiler, 2008:256

In an evangelical context such as the Lausanne Movement, we need to resource the youth also by tapping into the rich, but for many largely unknown, theological aesthetical heritage within that evangelical tradition. ${ }^{19}$ I have therefore chosen to introduce some selected theological aesthetical perspectives on film from evangelical theologians and cultural critics who would identify (explicitly or implicitly) with the overall theology and missiology of the Lausanne movement. ${ }^{20}$

John Stott was the leading Lausanne theologian from 1974-1989. He stressed the key missional concept of double listening, which is the art of carefully listening both to Scripture and to the contemporary world, in order to relate the one to the other. Stott pointed out in a famous admonition to Christian communicators: "If we can develop our capacity for double listening, will we avoid the opposite piffalls of unfaithfulness and irrelevance, and be able to speak God's Word to God's world with effectiveness today." (Stott, 1992:13)

\footnotetext{
19 Detweiler was a keynote speaker at the Lausanne Global Consultation on Media in LA in 2013.

20 See Dahle, Dahle \& Jørgensen, 2014:1-10.
} 
In his homiletics textbook, I believe in preaching, Stott advises Christian preachers and communicators "to see some of the most notable films and plays, since nothing mirrors contemporary society more faithfully than the stage and the screen" (Stott, 1992:13). He recounts founding a monthly 'reading group' in 1974, with the main purpose of seeking to understand "the secular mind of the post-Christian West, in order to combat it with a Christian mind" (Stott, 1992:13):

On several occasions, we have been to a film or play instead of reading a book ... The experience of the reading group - of the books we have read, the films and plays we have seen, and the discussion they have provoked - has not only increased our understanding of the modern world, but excited our compassion for human beings in their lostness and despair, confirmed our Christian faith and rekindled our sense of Christian mission. I recommend the value of such a group to all my fellow-clergy. There can hardly be a congregation in any culture, however small, which could not supply a few thoughtful people to meet with their pastor to discuss the engagement of the church with the world, the Christian mind with the secular mind, Jesus Christ with his rivals.

Stott, 1982:196-197

Stott's advice to preachers contains some implicit theological aesthetical perspectives, including the key notions that contemporary culture such as movies reflect being made in the image of God and express both human longings and human lostness. Therefore, there is great value in listening carefully - empathetically but critically - to the messages in influential movies.

One of the other significant speakers at the first Lausanne Congress in 1974 was Francis A. Schaeffer. In his paper on "Two Contents, Two Realities", he highlighted as 'the second content' the task to give 'honest answers to honest questions': "[We] must have compassion enough for a lost world to be willing to do the hard work that is necessary in order to answer their honest questions." (Schaeffer, 1975:363) For Schaeffer, such hard work included the need to understand 'the honest questions' communicated through key expressions and messages in contemporary culture, such as the influential movies by Federico Fellini and Ingmar Bergman. Heavily influenced by the Dutch art historian Hans Rookmaker, ${ }^{21}$ Schaeffer was seeking to understand such cultural expressions with a focus on the underlying worldview messages, and thus uncover significant worldview trends.

21 See esp. Rookmaker 1973. 
Schaeffer articulated his own theological aesthetics in the influential booklet Art and The Bible. This included his four criteria for assessing various forms of art: "What kind of judgment does one apply, then, to a work of art? I believe that there are four basic standards:

1. technical excellence,

2. validity,

3. intellectual content, the worldview which comes through, and

4. the integration of content and vehicle." (Schaeffer, 2006:62)

It is evident from these criteria, that Schaeffer considered art as having inherent value, as creative expressions of humanity as made in the image of a personal Creator.

Following Schaeffer's approach, a number of his co-workers at L'Abri Fellowship continued to explore present-day movies as cultural expressions of influential contemporary worldviews. One such L'Abri-worker was the literary critic Donald Drew, who published Images of Man: A Critique of the Contemporary Cinema in 1974. He claims that Christians need to learn about current 'images of man' from the contemporary cinema:

There is so much to be uncovered and learned about the human dilemma from the human experience in films. The slapstick, the sentimental, the satirical, the serious - each, like its counterpart on the stage or on a canvas or in a novel, should be accepted openly and fairly and criticized honestly and objectively. Of course, contemporary films both reflect and promote thought-forms and lifestyles, and most [current] films operate on non-theistic, existential postulates. Yet, each one is different and has to be accorded its own contribution and distinctiveness. Moreover, directors, in analysing the nature of man and the human dilemma, almost inevitably give some insights, which are true even from a Christian standpoint. Even when a Christian find a film's content to be false and misleading, he may praise the director and actors for their creativity and artistry.

Drew, 1974:101

Moving to the present time, it is natural to include (in passing) theologian, apologist and jazz musician William Edgar in this brief overview. ${ }^{22}$ His recent Created \& Creating: A Biblical Theology of Culture is an exploration in theological aesthetics. Edgar does not specifically address art in general or movies specifically, but his nuanced description of culture (as broadly defined) corresponds to Schaeffer and Drew's approaches to contemporary film as cultural expressions: 
Culture characterizes our calling here on earth. It distinguishes our common humanity, but also our differences. Culture can be positive, leading to human flourishing, or negative, bringing corruption and abuse. Components of culture are numerous and varied, making generalizations difficult. And although value judgments should be made cautiously, they are surely appropriate.

Edgar, 2017:10

As we have seen, Stott's principle on double listening and the Schaeffer/L'Abri tradition on cultural engagement are largely overlapping.

In view of the above narrative and selected overview of evangelical cultural critics, we may now articulate some theological aesthetical reflections on movies as a foundation for the holistic use of the multilevel approach to film in faith education.

1. Movie as a contemporary art form reflects the dual nature of humanity, both as gloriously made in the image of God and as being guilty sinners.

2. Movies are significant listening posts in the art of double listening, which provides us with key insights about the human dilemma and about influential worldview messages.

3. The consumption of movies has a key role in worldview formation across generations, but seems potentially to have a special influence on children and youth, thus providing us with a special window into significant meaning-making processes through visual storytelling and interpretation.

\section{Concluding Reflections: Integrating the Multilevel Approach to Film into a Holistic Faith Education Model}

In this chapter, I have outlined a multilevel approach to film, which enables us to include several interlocking features in the interactive story and meaning-making processes related to film. Whereas the emotional level takes the experiential aspects of the viewer(s) seriously and the aesthetical level focuses on the visual narratology, the worldview level explores how to identify explicit or implicit messages within a given movie universe. The normative level introduces a critical dialogue between the worldview of the viewer(s) and identified traces of worldview traditions and trends in a film. 
It is now possible to integrate this multilevel approach to film into a holistic faith education model where the task of double listening is central. I am here briefly outlining a critical threefold framework from previous research contributions, and indicating ways of implementing this framework in different educational spaces in order to equip and empower for engagement with movies. ${ }^{23}$

\section{Hermeneutics: Developing Interpretative Resources}

The media-saturated everyday life of children and youth, with movies playing a key role, creates a need for appropriate interpretative resources for worldview analysis. The multilevel approach outlined above provides Christian faith educators with such strategic resources for informed cultural critique. This includes a number of key insights, including:

1. the recognition that neither persons nor media messages are neutral,

2. the appreciation of the multifaceted nature of any worldview, and

3. the interpretation of the Christian faith as a worldview.

As a lecturer at a Christian university college in Norway, I have seen the significance and relevance of these key insights in our formal training for Christian communicators and faith educators. When communicated in appropriate ways, these hermeneutical insights are also foundational for responsible faith education in church, youth ministry and family contexts. In practical terms, this includes developing and using relevant teaching and learning material.

\section{Didactics: Developing Educational Resources}

Using the interpretative resources outlined above, leads to the uncovering of traces of secular and religious worldviews in fictional movie universes. To respond to these challenges, faith educators need theologically grounded, apologetically explicit and culturally relevant educational resources. Such resources should seek to demonstrate and illustrate the following:

1. The Christian faith as a coherent worldview story.

2. The Christian faith as a worldview story, which claims to correspond to metaphysical reality, historical reality and everyday life.

3. The Christian faith as a relevant worldview story, which claims to change and transform persons and cultures.

23 The theoretical framework is introduced in Dahle 2012 and Dahle 2014, whereas some practical applications and approaches are outlined in Dahle \& Skattum 2010, Dahle 2017 and Dahle \& Dahle 2018. 
It has been rewarding to construct a curriculum for our formal training for Christian communicators and faith educators around these key truth claims. There is a corresponding need for preaching, teaching, and learning activities in church and youth ministry contexts "to build a constructive apologetic culture ... in order to equip for holistic disciple making and mission" (Dahle, 2018:149). Furthermore, the appropriate communication of the central Christian truth claims is essential also for faith education in the family arena. Again, the need for relevant teaching and learning material is evident across these educational spaces.

\section{Formation: Developing Spiritual Resources}

Christian faith educators also need to develop formative spiritual resources, which may lead children and youth to personal growth towards spiritual maturity. This includes the following:

1. The nature of personal faith as trust provides an opportunity to compare and contrast faith in "one God and One Lord" (1 Corinthians 8:6) with religious and secular alternatives as illustrated in influential movie messages.

2. The relationship between "confessed faith" and "lived out faith" provides an opportunity to explore the privatisation of faith as a key challenge, especially related to the feeling of alienation in relation to secular movie universes.

3. The nature of worldview formation provides an opportunity to explore to what extent key worldview elements in influential movie messages may contribute to the identity formation of children and youth, thus demonstrating points of contact and points of tension between Christian faith and key movie messages.

It has been our experience in our formal training for Christian communicators and faith educators that there is a need for a dual emphasis on apologetics and spirituality. The significance of creating arenas for spiritual formation and growth is clearly seen also across church, youth ministry and family contexts. This includes developing and using teaching and learning material on media literacy and critique, with appropriate case studies.

\section{Bibliography}

Aadnanes, P.M. 2002. Livssyn. 3rd Edition.

Oslo: Universitetsforlaget.

Axelson, T. \& Sigurdson, O. 2005. Film och religion: livstolkning på vita duken. Örebro: Cordia.

Bennett, Z.; Graham, E.; Pattison, S. \& Walton, H. 2018. Invitation to Research in
Practical Theology. Abingdon: Routledge. https://doi.org/10.4324/9781351068246

Dahle, L. 2014. Media Messages Matter: Towards a New Missiological Approach to Media Engagement. Norwegian Journal of Missiology, 68(2): 105-120. 
Dahle, L. 2018. Cognitive Dissonance as a Missiological Challenge and Opportunity: An Evangelical Perspective on Western Europe. In: M.N. Behera, M. Biehl \& K. Jørgensen (eds.), Mission in Secularised Contexts of Europe: Contemporary Narratives and Experiences [Regnum Studies in Mission]. Oxford: Regnum Books.

Dahle, M.S. 2002. På sporet av livssyn: Utvikling og utprøving av eit analyseverkłøy - med ungdom som case. Unpublished MA thesis. Bergen: NLA University College.

Dahle, M.S. 2003. Spor av tru i ei tenåringssåpe? Om ungdomsmedia og religionspedagogen. Prismet, 54(3):99-1 16.

Dahle, M.S. 2006. Worldview Analysis of Popular Media. In: E. Grandhagen \& A. Myksvoll (eds.), Budskap 2006. Årsskrift for Fjellhaug Misjonshøgskole. Oslo: Fjellhaug. [Online]. Available: http://bit.ly/2WNS4UL

Dahle, M.S. 2012. Forskningsprosjektet '10-25' i religionspedagogisk perspektiv. Theofilos, 4(2):28-48.

Dahle, M.S. 2014. Tweens' mediehverdag som missiologisk utfordring. In: T.E. Hamre, E. Lundeby \& A. Redse (eds.), Barnetro og trosopplaering: festskritt til Egil Sjaastad på 65-årsdagen. Bergen: Fagbokforlaget. pp.207-228

Dahle, M.S. 2015. Livssyn - tre grunnleggende perspektiver. In: H. K. Dahlstrøm (ed.), Kors på halsen? Innføring i livssynsjournalistikk. Oslo: Cappelen Damm Akademisk. pp.22-39.

Dahle, M.S. 2017. Worldview Formation and the Disney Universe. A Case Study on Media Engagement in Youth Ministry. Journal of Youth and Theology, 16(1):60-80. https://doi. org/10.1163/24055093-01601005

Dahle, M.S. \& Dahle, L. 2018. Det kristne verdigrunnlaget i møte med medienes livssynsmangfold. In: N. Skrunes, G. Hagesœther \& B. Kvam (eds.), Skrunes grunnskoler. Begrunnelse - innhold - handlingsrom. Oslo: Cappelen Damm Akademisk. pp.227-254.
Dahle, M.S.; Dahle, L. \& Jørgensen (eds.). 2014. The Lausanne Movement: A Range of Perspectives [The Regnum Edinburgh Centenary Series, Vol.22.]. Oxford: Regnum Books.

Dahle, M.S. \& Kro, I.T. 2013. Hotell Caesar sett med norsk-somaliske øyne - om populœrkultur og verdiformidling. In: Ø. Økland (ed.), Innvandrerungdom og mediebruk: Norsk-somalisk ungdom i en global medieverden. Kristiansand: Portal Akademisk. pp.36-56.

Dahle, M.S. \& Kro, I.T. 2018. Disney som danningsagent. Med 'Frost' og 'Jake og sjørøverne i Drømmeland' som case. In: B.M. Nyjordet (ed.), Barns mediehverdag. Oslo: Cappelen Damm Akademisk.

Dahle, M.S. \& Skattum, L (eds.). 2010. Manus for livet? Film som verktøy i trosopplaringen. Oslo: IKO-Forlaget.

Detweiler, C. 2008. Into the Dark (Cultural Exegesis): Seeing the Sacred in the Top Films of the $27^{\text {st }}$ Century. Grand Rapids: Baker Academic. [Kindle]

Drew, D. 1974. Images of Man: A Critique of the Contemporary Cinema. Downers Grove: InterVarsity Press.

Edgar, W. 2013. Schaeffer on the Christian Life: Countercultural Spirituality [Theologians on the Christian Life Series]. Wheaton, III: Crossway.

Edgar, W. 2017. Created \& Creating:

A Biblical Theology of Culture. Downers Grove: InterVarsity Press.

Gravem, P. 1996. Livstolkning. Prismet, 47(6):235-274.

Johnston, R.K. 2006. Reel Spirituality: Theology and film in dialogue. 2nd Edition. Grand Rapids: Baker Academics.

Naugle, D. 2002. Worldview: The History of a Concept. Grand Rapids: William B Eerdmans.

Romanowski, W.D. 2007. Eyes Wide Open: Looking for God in Popular Culture. 2nd Edition. Grand Rapids: Brazos Press. 
Rookmaker, H.R. 1973. Modern Art and the Death of a Culture. 2nd Edition. Downers Grove: InterVarsity Press.

Schaeffer, F.A. 1975. Form and freedom in the church. In: J.D. Douglas(ed.), Let the Earth Hear His Voice: International Congress on World Evangelization. Minneapolis: World Wide Publications. pp.361-379.

Schaeffer, F.A. 2006. Art and the Bible (IVP Classics). Downers Grove: InterVarsity Press. [Kindle]

Sire, J.W. 1997. The Universe Next Door: A Basic Worldview Catalog. 3rd Edition. Downers Grove, III.: InterVarsity Press.
Sire, J.W. 2009. The Universe Next Door: A Basic Worldview Catalog. 5th Edition. Downers Grove, III.: InterVarsity Press.

Sire, J.W. 2015. Naming the Elephant: Worldview as a Concept. 2nd Edition. Downers Grove, III.: InterVarsity Press. [Kindle]

Stott, J.R.W. 1982. I believe in Preaching. London: Hodder \& Stoughton.

Stott, J.R.W. 1992. The Contemporary Christian: An Urgent Plea for Double Listening. Leicester: InterVarsity Press. Thiessen, G.E. 2004. Theological Aesthetics: A Reader. Grand Rapids: William B Eerdmans.

Watkins, T. 2007. Focus: The Art and Soul of Cinema. Milton Keynes: Authentic Media. 


\section{Introduction}

In recent decades, Catholic Religious Education (CRE) has been increasingly justified by the support it can provide adolescents to become subjects of life, as well as by its potential to provide opportunities for meaning-making. Therefore, this chapter will explore how these functions of CRE can become more possible through the creative pedagogy of Media Literacy Education (MLE) and the digital technologies it utilises for storytelling, especially photography and videography. This exercise will also facilitate the exploration of ways through which creative story-telling can effectively become a means for transcendental reflection, thus promoting a narrative pedagogy for CRE that contributes significantly to holistic adolescent identity formation. This chapter will finally reflect on the results of a small scale qualitative pilot study that points to a potential dialogue between CRE and MLE. This chapter demonstrated how skills learnt in MLE, especially photography and film-making, may be efficiently used to help students during CRE lessons interpret life experiences and discern their purposes in life through the lens of their Catholic faith, thus becoming subjects of their lives.

Since the publication of Erikson's theory of psychosocial development, research has seen a significant surge of interest in the understanding of identity development, especially during the period of adolescence that is so crucial to young people's quest for transcendence and search for answers to fundamental and existential questions. Adolescents ask such questions in relation

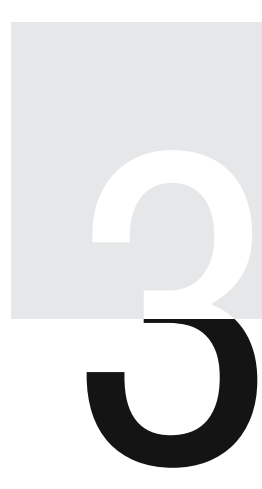

\section{FACILITATING HoLISTIC IDENTITY} FORMATION OF AdolESCENTS USING DIGITAL MEDIA

A Dialogue between Media Literacy and Catholic Religious Education

Edward Wright 
to themselves, each other and the world, and they frequently center on one's past, present and future life, revealing the person's need to seek unity of purpose and coherence. This endeavour is integral to the adolescent need to explore issues related to transcendence, spirituality and faith, essential aspects of one's identity and personality. Most young people in today's highly technological era seek meaningful answers to such questions on and through the digital media, by either reflecting on what others think and say and assimilate it, or create their own digital productions through which they express their thoughts, reflections and emotions. Often they opt for both. Since multimodal spaces are ideal sites for adolescent identity construction, media educators have recently focused more on youth as 'media producers', and more specifically as authors of multimodal productions as opportunities to create narratives of self (Kress \& Van Leeuwen, 2006).

The literature review that follows will seek to demonstrate the relationship between the notion of transcendence in adolescence and its possible acquisition through a narrative-hermeneutical-developmental approach to learning. This will be done by bringing together Paul Ricoeur's notion of an "inherent correlation between narrative and lived experience" (Lunde-Whitler, 2015:294), Charles Taylor's belief in the inter-subjective/social/relational and moral dimensions of narrative learning, and Robert Kegan's constructive-developmental approach that is concerned with both the construction of an individual's understanding of reality and the development of that construction to more complex levels over time.

\section{A Narrative-Hermeneutical-Developmental Approach to Learning}

Ricoeur (1984) reflects deeply on why he believes that stories are the best vehicles known to human beings for conveying how and why a human agent, endowed with consciousness and motivated by intention, enacts desires and strives for goals over time. Through stories people make sense out of life and such a meaningmaking process is common to all people across various times and cultures. Then, in his book Oneself as Another (1992), he elaborates even further on the correlation between narrative and lived experience, by stating that human beings learn how to understand themselves and even shape a worldview in terms of stories. In this way Ricoeur shows that identity formation is such an important and significant developmental task that takes place over the whole span of one's lifetime. Ricoeur's hermeneutical cycle that lies at the heart of his narrative theory, and that views one's consciousness as an act of mediation between the experiencing of life (text to be read) and the multiplicity of internalised historical narratives ('context'), out of 
which stories flow with meaningful connection, understands the process of identity formation as dynamic and in constant evolution. However, the act itself of articulating lived experience through life-stories also provides stability and constancy to identity.

Ricoeur was greatly influenced by the philosopher Aristotle, an influence that helped him formulate his theory of mimesis, through which he could offer insights on narrative identity development and learning that go well beyond the mere concepts of 'assimilation' and 'accommodation' proposed by the Swiss clinical psychologist and researcher in child development Jean Piaget. For Ricoeur (1990; 2005), the act of narrating can be described as an act of mimesis-praxeos that is a creative imitation of action. This is at the same time an act of poeisis, where imagination and creativity are both engaged through the plot ('muthos') (Ricoeur, 1990). This human capacity is also mentioned and explained by Ricoeur (2005:278) in his studies on hermeneutics and the human sciences. He states that "the activity of narrating does not consist simply in adding episodes to one another; it constructs meaningful totalities out of scattered events. The art of narrating, as well as the corresponding art of following a story, therefore requires we are able to extract a configuration from a sequence".

Charles Taylor believes that the inter-subjective/social/relational and moral dimensions in our narrative learning that is so pivotal in the construction of our "selves", are crucially important and absolutely necessary. Taylor's perspective is significantly dependent upon the recognition that each individual is a "self only among other selves" (Taylor, 1989:35), "a self among interlocutors" (p.29), a "dialogical self" (Taylor, 1995:230), a self that exists within "webs of interlocution" (Taylor, 1989:36) that also requires a language. Identity could only be constructed "through a language of interpretation" (p.34) that is always formed in exchange with the "significant others", the people who really matter to us and who deeply impact and shape our lives. All throughout our life span, such people, whether physically present or not, always act as interlocutors who are essential to me for achieving my self-definition and who are now critical to my continuing grasp of language of self-understanding "and my relationship to both can overlap" (p.36). In this sense, Taylor uses the word 'language' to refer not only to the words that we articulate verbally, but even more so, to the language of norms, gestures, age, community, tradition, and culture, with all the elements embedded in it (p.35). These are also modes of strong evaluation, according to Taylor, through which we become fully human agents, understand ourselves, define, redefine and discover our identity (Zhao \& Biesta, 2012). Finally, but certainly not the least important, is the fact that Charles Taylor believes that the coordinates of self-identity are fundamental in moral essence. In the continuous process of learning about one's self and the 
world around us that leads to identity formation, there is a "moral space" that is so fundamental. In Taylor's own words (1989:28), to "know who you are is to be oriented in moral space, a space in which questions arise about what is good or bad, what is worth doing and what not, what has meaning and importance for you and what is trivial and secondary".

From a psychological point of view, the influential American psychologist and author Robert Kegan has developed a constructive-developmental theory, so called because of its concern with both the construction of an individual's understanding of reality and the development of that construction to more complex levels over time. In it he proposes five distinct stages, or better still as he refers to them, "orders of the mind", through which "transformation" occurs as people progress to qualitatively different stages of meaning-making. Although new information may add to the things a person knows, this transformational learning is not simply learning new information or skills, but it changes the way a person can know those things. According to Kegan, this is transformational changes that are the very form and essence of the meaning-making system. It makes young people more complex, but at the same time more capable of dealing with multiple demands and uncertainty that are so much part of the fabric of the postmodern world and culture (Berger, 2002). In this constructive-developmental approach, transformative learning always results when an individual is able to step back and reflect on something and make decisions about it. Thus, for Kegan (1994:17), transformative learning happens when someone changes, "not just the way he behaves and the way he feels, but the way he knows ... not just what he knows, but the way he knows".

\section{Holistic Identity Development and Human Meaning-Making}

These three approaches can come together, enrich the concept of transformative learning and show how it can occur in the context of everyday life. They can manifest how the construction of the life story can interact with the author's transformative learning. This is due to the potential of narrative learning to alter/modify the learner's self-understanding, worldviews and ways of being in the world (Nelson, 1997). The process of mimesis-poeisis and the gradual shift of subjects into objects are at the heart of narrative learning, and through imagination and critical thinking, they make learning from experience not only possible, but a continuous process throughout all the life stages. This sustains the ongoing formation and reinvention of the narratives of life.

In the narrative-hermeneutic perspective of Taylor and Ricoeur, narrative learning is intimately tied to interpretation and this makes it transformative in nature. Thus, both a narrative-hermeneutical and a constructive-developmental approach to identity and 
learning enhance our understanding of how an individual's retelling of his stories in a co-operative inquiry provides the occasion for further interpretation. In other words, narrative learning can bring about real transformation, not only from conscious analysis, but also from a poetic or contemplative attending (Nelson, 1997) to one's experience and the life narrative. This process of mimesis-poeisis through the engagement of imagination and critical thinking corresponds to the formation of a critical consciousness, referred to by the famous Brazilian educator and philosopher Paolo Freire (2004:90) as 'conscientization'. This includes the uniquely human ability to integrate self-constitutive stories, "marked by a development in one's sense of personally-owned vision, of responsibility to others, and of purpose - all towards a greater self-consistency and integrity" (Lunde-Whitler, 2015:307). However, it also encompasses the negotiation of one's life stories in relation to the various paradigms that were internalised and shaped prior to one's life experiences and the mimesis-poeisis process applied to them.

It must also be said that the correspondence between a narrative-hermeneutical and a constructive-developmental approach has the potential to deepen the analysis of narrative properties and bring forth more relevant roles of learning such as the cognitive process (Luckin, Plowman, Laurillard, Stratfold, Taylor \& Corben, 2001), organisational principle (Polkinghorne, 1988), external knowledge representation (Porter Abbott, 2002), mediator of human action (Wertsch, 1998) and way to structure human experience (Aylett, 2006). It must be also made clear that the transformation brought about by narrative learning is not only related to the cognitive realm of the individual, but also to the emotional (affective) and the conative (motivational/volitional) dimensions/domains of learning (Dettori \& Paiva, 2009). By contributing to such learning domains, narrative learning challenges and stimulates fantasy and curiosity: elements of intrinsic motivation that are crucial to the taxonomy suggested by Thomas Malone and Mark Lepper (Mcquiggan, Mott \& Lester, 2008). This is due to the fact that narrative in all its forms is a dialectic between what was expected and what came to pass, (Bruner, 2003:15) as well as an invitation to problem finding, not a lesson in problem solving (Bruner, 2003:20). On the other hand, the affective domain is also of pivotal importance to narrative learning as stories are based on interplay between characters and causation (Ayleft, 2006). Such interplay would necessarily and inevitably involve aspects of one's emotional state, social standing, personality and the intentions and motives that underlie the characters' actions (Dettori \& Paiva, 2009:58). 


\section{Developing a 'Christian' Narrative Identity during Adolescence}

A narrative-hermeneutical-developmental approach to CRE can really be the means through which the subject would achieve some of its most important aims, namely to contribute to the development and formation of one's identity, moral and ethical responsibility, living in a community with respect to diversity and in true love of thy neighbour, understanding and construction of the Maltese culture and identity, and the understanding of how religion sustains and contributes to the development of societies, in particular western society, through the arts, politics, sciences, education and philosophy. Also, when RE/CRE promote narrative learning through a narrative-developmental perspective, this can help overcome the postmodern world's tendency to trivialise understandings of meaning and value by fostering hope in religious traditions and practices. It also helps young people understand and critique their social and cultural identity to move beyond the given values and norms, and develop an identity that is relational, open and equal.

Even though the importance of narrative for identity formation can be traced back to the early years of childhood, it becomes particularly significant during preadolescence and adolescence, the time when young people develop the capacity to think about the relationship between the past, present, and future, and how their life narratives make sense across time periods (Cohler \& Hammack, 2007; Halverson, 2010). It is during early adolescence, around the age of 12 , that the ability to create coherent life narratives starts to develop, a skill that is intimately related to and much dependent upon the capacity for autobiographical reasoning, the ability to link together single life events in a way that defines the young person's identity and personality and creating a meaningful story (Chen, McAnally \& Reese, 2013; Halverson 2010;). In adolescence, autobiographical reasoning has potential to become a constructive memory process that forges links between single life episodes, making connections between and provides interpretations of various life experiences. Such reasoning has been positively related to identity formation (Chen et al., 2013; Steiner, Pillemer, Thomsen \& Minigan, 2016).

\section{The Need for Transcendence in Adolescence}

In research the notion of transcendence is intimately related to that of spirituality and spiritual development, and is considered to be of significant interest to various fields of knowledge, including and especially those of psychology, theology and religious studies/education, philosophy, sociology and other humanistic subjects. It is quite commonly referred to as the 'search for the sacred'. In this short, but powerful definition, the word 'sacred' signifies an individual's concept of God or 
other areas of life that may take on divine character and significance through their association with divinity (Pargament, Exline \& Jones, 2013). Within the realm and field of spirituality, transcendence is also related to the pursuit of meaning, existential beliefs and ultimate belonging (Benson, Roehlkepartain \& Scales, 2010; Lerner, Roeser \& Phelps, 2008). Quite often in literature, transcendence means an awareness of or connection to something beyond one's self, that may or may not include God or a transcendent reality, but frequently includes aspects of life that have divine-like qualities, such as immanence, ultimacy, and boundlessness (Pargament et al., 2013). A few studies conducted so far on adolescents show that transcendence and spirituality are very much related to each other and are of great significance at this age. They also show that transcendence, or a feeling of personal connection with something infinitely greater than themselves, can and most often does occur beyond the confines of institutionalised religions and traditional religious practices (King, Ramos \& Clardy, 2013; Rich \& Cinamon, 2007; Sallquist, Eisenberg, French, Purwono \& Suryanti, 2010).

It is also very interesting to observe that such definitions and implications of transcendence are also being researched from a psychological developmental systems perspective. In this respect, research has and is still exploring transcendence in adolescence in relation to its impact on the ongoing transactions between people and their multiple embedded contexts (Lerner, 2006). Through such interactions, young people experience something of significance that is beyond their reach, and grow in a sense of transcendence in regard to God, a divine entity, a religious community, humanity, friends, or even nature. Lerner et al. ,(2008) described this focus as shifting a young person's cognitive and emotional orientation from the self to a transcendent other in such a way that provides ultimate purpose and value beyond material reality. In this sense, spiritual transcendence provides meaning and serves to motivate contribution to the well-being of the greater world (Lerner et al., 2008). Current literature shows that adolescent transcendence is significantly related to the pursuit of purpose, relatedness, belonging, awareness, existential questions, one's passions and even the need to offer service to others and to society (King et al., 2014). However, King and his colleagues (2014) acknowledge that despite the growing attention to this sphere of human development, only very few empirical research studies have until now explored and/or tested these notions of transcendence and spiritual development among adolescent populations. 


\section{CRE as a Path to Transcendental Reflection}

If this narrative-hermeneutical-developmental approach to CRE is implemented successfully, it is hoped that religious educators would be able to re-define their roles in a pluralistic society in which religious meaning-making is occurring continuously without their intervention and often within unexpected contexts. They would realise that it is crucially important for them to be "interpreters of culture rather than transmitters of doctrine - speaking both to and from the church about the ways in which the Holy Spirit is moving in the world" (Hess, 2004:154). This would require a pedagogical transformation from a linear, instrumental paradigm to a communal, dialogic model - a shift to "knowing how" rather than "knowing that" (p. 155). Taking such a position, Hess, a Roman Catholic education scholar, situates her theoretical work squarely within a critical/cultural approach in which understanding the process of the consumption and production of media would be more instructive than analysing the process of decoding the content (Hess, 2003).

Religious identity starts to develop with the individual's interpretation of his or her life story from a transcendent perspective. Establishing coherence to one's life story has been shown to be directly related to the formation of religious identity (Miedema \& Roebben, 2008). Thus, the formation of one's personal and religious identity occurs as a hermeneutic process in the light of the prevailing narratives present in the surrounding culture. When these narratives are internalised, the individual enters the life histories and narrative traditions of others (Ricoeur, 1992:154-156). Roebben (2009) insists that young people need to be listened to carefully and urgently, and teachers need to empathise with their life experiences, making these the starting point or the spring board to the appreciation of a particular religious identity, such as a Christian identity. This is built on the view that students are "human beings with their own existential longing, with their own soul" (p.163), and that they "have the right and the ability to share with each other and to theologise about their personal and communal lives" (pp. 181-182). Since most young people today have such a strong attraction and passion for the digital world and spend long hours every day roaming around the virtual reality of the internet, which has become for them a 'natural habitat', it is crucial for educators to understand how the multimodal productions they produce and upload reveal aspects of their identity and some of the ways through which they interpret significant life events, past and present, as well as how they project themselves into the future. 


\section{The Impact of 'Youth Participatory Cultures' on Adolescent Identity}

In recent years, an increasing awareness of "youth participatory cultures" (Jenkins, Clinton, Purushotma, Robinson \& Weigel, 2009) has lead media educators and researchers to focus more on young people as 'media producers' and more specifically on multimodal production as a new form of literacy (Halverson, 2010:2356). As Prensky (2001) had observed, the beginning of the 21 st century was already experiencing a generation of "digital natives". Many of these young people, referred to as "prosumers" by Lister, Dovey, Giddings, Grant \& Kelly (2003), are becoming fluent in the "new literacies" by way of which they both create digital products and upload them online, and consume popular images, combining, adapting and incorporating them into their own media productions (Lankshear \& Knobel, 2003). Many of these productions are used by adolescents and youth to tell stories about themselves, about who they are and who they would like to be. They are often nonlinear and multivoiced, and reflect several identity processes that are taking place in adolescence (Weber \& Mitchell, 2008). Given that the processes of producing, consuming, and being shaped by these digital technologies occur simultaneously and are intertwined, they become ideal entry points for the exploration of learning in relation to identity formation, for it is precisely through such processes that that adolescent/youth identity is constructed and deconstructed, experimented with, shaped and experienced (Buckingham, 2008; Lister et al., 2003).

Research indicates that there is a direct and significant relationship between the video/film production process and identity formation (Vargas, 2006). Moreover, it also demonstrates that film, as a medium, offers young people an effective way to produce narratives of themselves (Kress \& van Leeuwen, 2006). It may indeed represent the ideal medium for "accessing an unmediated relationship with the real" (Fleetwood, 2005:157). While digital technologies can have a considerably strong impact on identity through the process of merging words, rhyme, rhythm, imagery and music, as well as movement, film becomes a more dynamic and effective medium for representing the self (Kress \& van Leeuwen, 2006; Halverson, 2010). It is through these propensities that film becomes a core tool for meaning-making and therefore a window on transcendence. In learning how to construct a life story from one's own personally significant experiences, adolescent students in the CRE classroom can be brought into a more critically engaged relationship with such a story, with those of other students, as well as with the most significant traditions and narratives of the faith community or religious tradition they belong to, as is the case in Malta. Much of the research until now that focused on storytelling in religious education occurred in non-digital settings and viewed religious education 
in a broad sense, not tied to a particular religious tradition (Conde-Frazier, 2007; Miedema \& Roebben, 2008). If the formation of a narrative identity occurs as a crucially important hermeneutic process throughout one's life, and the same could be said of one's religious narrative identity, research projects and studies need to be conducted with the aim of understanding how digital technologies, especially photography and film-making, can facilitate identity formation through CRE. This is precisely the main aim of the pilot study conducted recently and presented in the next section of this chapter.

\section{Empirical Study in a Maltese Church School}

Between January and April of 2018 I conducted a small scale pilot study at Bournemouth University. My aim was to put into practice, as a teacher-researcher, the narrative-hermeneutical-developmental approach to learning and identity explained and elaborated upon in this paper. I applied it to a specific topic of CRE that is taught in the year syllabus of the student-participants, through the use of digital tools they learn and skills they acquire in their MLE class. The pilot study was designed to explore how a narrative-hermeneutic-developmental approach to learning and identity can be applied to CRE through the use of digital tools such as video production and photography, in a way that enhances the students' creativity and simultaneously provides them with opportunities to reflect critically on life experiences. In this learning process students could thus construct their own identity in a narrative way, opening up possibilities for them to explore aspects of transcendence and meaning-making that are vital to their spiritual and faith formation. The aim is to explore possibilities for dialogue, between MLE and CRE, that could contribute to adolescents' holistic human development.

The participants were 20 female students in Year 8 (ages 12-13) from a Maltese Church secondary school. All participants were Maltese and came from diverse cultural and socio-economic backgrounds. They all have CRE in their school curriculum as a compulsory subject, as well as MLE that they chose as one of their optional subjects. The sample was both convenient and purposive.

\section{Research Design}

To achieve the purpose of the study, a hybrid research design was applied, combining the use of a preliminary questionnaire (quantitative research technique) to a digital ethnographic approach with Consensual Qualitative Research (CQR) strategies for data collection, namely semi-structured in-depth interviews and a focus group study in the form of day seminars. 


\section{Ethical Considerations}

All the research techniques and instruments used for this pilot study were approved by the Research Ethics Board of Bournemouth University after the necessary revisions were made before the actual pilot study started. Official permission from the Secretariat for Communications (Curia Communications Office) was also obtained.

\section{Data Collection}

A preliminary questionnaire was prepared and filled in anonymously by all the students of Year 8/Form 2. These were collected per class, so that the results of the questionnaires from the MLE class could be compared to the others. Its main objectives were to assess the attitudes of the students towards CRE and MLE, and their underlying reasons, to reveal the extent to which they liked and felt competent in and familiar with photography and video-taking, and to know whether they believed in the potentiality of such creative and technological tools to enhance the pedagogy of CRE. The questionnaires also provided valuable feedback from the students as to what fears they may have related to a narrative approach to learning applied to CRE.

Then, since a digital ethnographic approach with CQR strategies were applied to this study, two focus group research seminars and seven semi-structured in-depth interviews were conducted on scheduled dates that were at the school's convenience. Six students and the teacher were interviewed on two different days one week apart, after the second focus group seminar was completed. In between the two focus group seminars the students were expected to complete the main task of the project, i.e. to make a short film/video that would speak about their faith. This would include the filming of a "metaphor" for their faith, a short interview, and other footage of their choice. To facilitate this task for them, they were given the opportunity to participate in two basic editing sessions at the Media Center (Maltese Church production house).

During the first focus group meeting/research seminar the students were taken to a nice venue outside school and they had the opportunity to start working on their final product through small practical tasks that required taking photographs and filming. Then, during the second whole day focus group meeting/research seminar, the students showed their final audio-visual product to each other, and these served as a starting-point for discussion among the students. The topic chosen for the seminars and for their main task was "You and Your Faith on the Journey" from their Year 8 syllabus of CRE. This helped the researcher understand how media, especially digital technologies, could facilitate CRE by making the content of the syllabus more relevant and interesting while relating it to the students' lives, past, present and future. 


\section{Data Analysis}

The Ricoeurian method of interpretation was used combined with narrative and thematic analysis approaches on both the transcripts of the seminars and of the in-depth interviews. In this process I was assisted by both the teacher and the two Learning Support Educators who were present at every stage of the data collection. This provided more objectivity to the study, as well as the possibility of agreeing on a range of broad categories and a series of themes that emerged from the data analysis, related to each other, to the lives of the participants, and to the application of specific pedagogies in MLE and CRE. These are briefly described and discussed below, with citations from the student participants' own contributions.

\section{Appeal of Photography and Film-Making to Adolescents}

Many of the participants' responses in the questionnaires and interviews showed that they strongly believe that photography and film-making can serve as catalysts for creativity, and through creativity they can engage students more in learning different curricular subjects such as CRE. All the pupils interviewed acknowledged that their decision to self-disclose personal experiences was facilitated by the short videos they produced. They admitted that through such media they could express what otherwise would be too difficult and embarrassing. Moreover, each video they watched encouraged them more to reflect and elaborate verbally on theirs after showing it to the group. It also came out clearly that the facilitation of expression was the result of the whole pedagogical process the pupils went through and not just of their finished products. Throughout this process in which they worked a lot together, including having to interview and film each other, they learnt that the exchange of narratives in a community is at the heart of the education in and cultivation of one's inner faith. They realised that the sharing of life stories plays a crucial role in developing one's understanding of life's purpose and meaning, in relation to God's purposes for the world. That is to say, one could re-interpret life experiences in a positive and empowering manner when these encounter the experiences of others in a community of learning, thus making empathy and compassion both possible and real. This was possible through the application of photography and film-making skills, albeit basic, that are so appealing to adolescents. This could be all summed up in one student's statement:

I believe the videos helped a lot. If only we are given such opportunities to use videos in the CRE and PSCD lessons! It would help a lot, especially if you are shy and find it difficult to express yourself in front of the class ... the video will do the talking in front of the class ... 


\section{Faith as and from Transcendence}

Data from both the interviews and the focus group seminars revealed that all the students feel the need to reach beyond themselves and serve something greater. In various ways they are engaged in meaning-seeking and meaning-making processes which empower them to reflect upon their past and present life, and at the same time plan their future while looking forward to realizing their dreams. All the participants were believers in God, and consequently God was their major source of experiences of transcendence. For many of them God was perceived as a person with whom they can connect and build a relationship of trust, and in whom they can find a source of meaning, strength, courage and resilience in the face of challenges, painful experiences and incomprehensible life events. Another finding from the data analysed was that most pupils mentioned or spoke about God in their lives in relation to their relationships to other people. They reflected upon a simultaneous sense of connection to God and to the 'significant others' in their lives, especially their family and friends. As one student stated:

I believe in faith because my grandma died about two years ago and I loved her very much. She used to believe in God. She used to tell me a lot of things about him and because she really believed in what she said, it sort of strengthened my faith as well.

Most of the participants acknowledged that through God they got a deeper connection to others, and simultaneously felt a stronger connection to God after they would have been shown empathy by others after going through a negative experience that triggers the feeling of negative emotions.

Another very interesting and significant observation and finding of this pilot chapter was that most pupils chose a natural object as a metaphor for their faith. Moreover, a significant number of them expressed a sense of transcendence that transpired from their love for and admiration of nature, and occurred in the context of nature. One student expresses such a feeling when she states:

I chose the metaphor of the tree because as we get older we have more faith in us and we get stronger. I have more leaves and its roots grow so big and go down very deep in the soil ... this for me means more faith as we become more mature and our faith becomes much deeper and stronger.

Through their attachment to animals, some students even expressed, albeit unconsciously, their need for positive attachment to others, as well as a sense of transcendence that transpires from the experience of pain as a result of a significant loss in life. It seems that the latter has the potential of helping young adolescents 
face death of 'significant others' as an inescapable and inevitable reality of life. Through such experiences they also came to realise more the finitude of human life.

\section{Faith as Interpretation of Life Events}

One student felt comfortable enough to share her belief that:

everything happens for a reason. Every experience we go through helps us grow and believe more. Today a month ago my grandpa passed away. He was like my father to me since my parents are separated. He helped me to keep strong, to believe more.

An interesting finding was related to how photographed and filmed metaphors chosen by students to reflect on and describe their life and faith, helped them experience life on a deeper level. Metaphors seemed to help the adolescent participants compare life to relatively more concrete and structured concepts, considering that life's meaning can be difficult to grasp and the experiences that comprise it not easy to interpret in a positive way that empowers one to move forward with hope. Metaphors through the camera helped them to simultaneously engage their imagination and critical sense of reflection on life experiences, and filter their meaning through the pupils' religious beliefs and worldviews. It pointed to metaphor's potential to give relevance to and shed light on the relationship between the participants' religious creed and everyday life. Most students also expressed their belief that challenging moments in life could be transformed into opportunities for growth. This is due to the strength that one could constantly receive from God. This strength is a direct result of one's faith and trust in God who never lets down those who love Him. This conviction also seems to point towards an attachment transfer to God who can provide security and compassion, as well as courage and strength. Many participants narrated personal life experiences characterised by signs and symbols that are particularly significant both to the Catholic religion and to the Maltese culture in general. This occurred mostly when they recounted those special occasions in their lives when they received Catholic sacraments for the first time. It seemed that such moments were very significant reference points in their memory that remain sources of psychological and moral strength throughout life's journey. 


\title{
Faith, Attachments and Relationships
}

\begin{abstract}
Yes, because there were people who I barely knew and now I got to know better. I learnt how to see from their perspective ... I shared something that was very personal. And when I find someone who can trust me with personal experiences that they normally don't disclose, I feel comfortable enough to do the same. And I feel connected to them. And that connection makes me reflect upon so many things.
\end{abstract}

This statement by one student participant reveals another very significant theme that emerged from this pilot study, namely the need for positive and secure attachment that adolescents feel. They spoke both of attachments with animal pets and with people, especially parents, relatives and peers. Reflecting on these attachments in memory seems to facilitate their path to transcendental reflection on spiritual and religious realities, such as the finitude of human life, the significance of death in the human journey of life, the meaning of negative life events that cause much pain to the human heart and the potential learning and empowerment for the future through imagination that could result from such reflection on one's past attachments. It seems that one's faith in God, and its value, relevance to and significance in the everyday life of these young people transpires from the engagement of reflection on one's past and present attachments along life's journey. There also seems to be a tendency for young adolescents with seemingly secure attachments, to identify themselves with the standards of their parents or other 'significant others'. They also tend to transfer attachment components to God, and through such transfer they redefine their concept of God and their belief of what and how God can have a significant impact on their lives. The participating pupils described a simultaneous sense of connection to God and to other people. Most of them expressed their satisfaction and gratitude of having the opportunity to share some of their personal life experiences of suffering with the whole group, in which they felt part of a community that genuinely empathised with them. Almost all acknowledged that such a positive feeling of compassion that resulted from being empathised with, created comfort to express personal experiences and in turn this sharing led to a deeper faith in God and in the tenets of their religion which now made more sense.

Moreover, the participants did not just remember their experiences with people who were significant to them, both in their past life and in the present, but they also re-interpreted the meaning of these experiences in relation to their present situation and their future desires, as well as in the light of their Catholic beliefs and values. Through such re-interpretation in memory of significant life events/experiences in the light of faith, the participants experienced their faith as a source of empowerment, especially in the dark moments of life. Most of them spoke of such empowerment as 
transpiring from the sense of hope that their faith provides them with, especially in the context of community. The use of digital technologies, give voices to the student participants' painful experiences that marked their life journey. Through these narratives of pain and suffering, many of the students reflected quite profoundly on how their traditional Christian/Catholic beliefs and practices helped them search for meaning. Some expressed how their faith in a loving and compassionate God helped them through difficult experiences. To others it seems that such painful experiences could challenge their belief in and understanding of God, as well as their concepts of Him as being loving and just.

\section{Conclusion}

This pilot study served the purpose of exploring how self-narratives could be created, experienced and shared by adolescents in interaction with one another and the self, in the context and setting of the CRE class. This curricular subject can help students develop a human narrative that "mediates between the canonical world of culture and the more idiosyncratic world of beliefs, desires and hopes" (Bruner, 1990:52). It also demonstrated that CRE could indeed facilitate the dialectic between the complexities of adolescents' developing identities and the related "veritable cultural sea of narratives, narrative-fragments, images, symbols, rituals, relationships, roles, cultures, sets of practices, etc., in which we are all immersed" (Lunde-Whitler, 2015:309). Moreover, it showed that CRE could concretise an exchange of narratives in a class/community setting that is at the heart of education in and for faith. Through this exchange CRE would be contributing to adolescents' identity formation by helping them find their role as subjects of life. Furthermore religious education can enable young people to become critical of their own past experiences, by empowering them to meet life's challenges.

\section{Bibliography}

Aylett, R. 2006. And they both lived happily ever after? In: G. Dettori, T. Giannetti, A. Paiva \& A. Vaz (eds.), Technology-mediated narrative environments for learning. Rotterdam. Sense Publishers. pp.5-25.

Benson, P.L.; Roehlkepartain, E.C. \& Scales, P.C. 2010. Spirituality and positive youth development. In: L. Miller (ed.), The Oxford handbook of psychology of spirituality and consciousness. New York: Oxford University Press. pp.468-485.
Berger, J.G. 2002. Exploring the connection between teacher education practice and adult development theory. Doctoral dissertation, Cambridge, MA: Harvard University.

Bruner, J.S. 1990. Acts of meaning. Cambridge, MA: Harvard University Press.

Bruner, J.S. 2003. Making stories. Cambridge, MA: Harvard University Press.

Buckingham, D (ed.). 2008. Youth, Identity and Digital Media. Massachusetts: Massachusetts Institute of Technology. 
Chen, Y.; McAnally, H.M. \& Reese, E. 2013. Development in the organization of episodic memories in middle childhood and adolescence. Frontiers in Behavioral Neuroscience, 7:1-9. https://doi.org/10.3389/ fnbeh.2013.00084

Cohler, B.J. \& Hammack, P.L. 2007. The psychological world of the gay teenager: Social change, narrative, and "normality". Journal of Youth and Adolescence, 36:47-59. https://doi.org/10.1007/s10964-006-91 10-1

Conde-Frazier, E. 2007. Culture and the production of religious knowledge and interpretation. Religious Education, 102(2): 1 1-115. https://doi. org/10.1080/00344080701285196

Dettori G \& Paiva, A. 2009. Narrative Learning in Technology-Enhanced Environments. In: N. Balacheff, S. Ludvigsen, T. de Jong, A. Lazonder \& S. Barnes (eds.), Technology-Enhanced Learning, 55-69. Springer: Dordrecht. https://doi. org/10.1007/978-1-4020-9827-7_4

Fleetwood, N.R. 2005. Authenticating practices: Producing realness, performing youth. In S. Maira \& E. Soep (eds.), Youthscapes: The popular, the national, the global. Philadelphia: University of Pennsylvania Press. pp.155-172.

Freire, P. 2004. Pedagogy of indignation. Boulder, CO: Paradigm Publishers.

Halverson, E.R. 2010. Film as Identity Exploration: A multimodal analysis of youth-produced films. Teachers College Record, 112(9).

Hess, M.E. 2003. Marriage on TV. Word \& World, 1:48-56.

Hess, M.E. 2004. Transforming Traditions: Taking Popular Culture Seriously in Religious Education. Religious Education, 99(1):86-94. https://doi. org/10.1080/00344080490273529

Jenkins, H.; Clinton, K.; Purushotma, R.; Robinson, A.J. \& Weigel, M. 2009. Confronting the Challenges of Participatory Culture: Media Education for the $27^{\text {st }}$ Century.
London: MIT Press. https://doi.org/10.7551/ mitpress/8435.001.0001

Kegan, R. 1994. In over our heads: The mental demands of modern life. Cambridge, MA: Harvard University Press.

King, P.E.; Ramos, J. \& Clardy, C. 2013. Adolescent Spiritual Exemplars: Exploring Spirituality in the Lives of Diverse Youth. Journal of Adolescent Research, 29(2): 186-212. https://doi.org/10.1 177/0743558413502534

Kress, G. \& van Leeuwen, T. 2006. Reading images: The grammar of visual design. 2nd Edition. New York: Routledge. https://doi. org/10.4324/9780203619728

Lankshear, C. \& Knobel, M. 2003.

New literacies: Changing knowledge and classroom learning. Berkshire, UK: Open University Press.

Lerner, R. M. 2006. Editor's introduction: Developmental science, developmental systems, and contemporary theories. In: R.M. Lerner (ed.), Theoretical models of human development. Vol. 1 of Handbook of Child Psychology. 6th Edition. Hoboken, $\mathrm{NJ}$ : Wiley.

Lerner, R.M.; Roeser, R.W. \& Phelps, E (eds.). 2008. Positive youth development and spirituality: From theory to research. West Conshohocken, PA: Templeton Press.

Lister, M.; Dovey, J.; Giddings, S.; Grant, I. \& Kelly, K. 2003. New media: A critical introduction. London and New York: Routledge.

Luckin, R.; Plowman, L.; Laurillard, D.; Stratfold, M.; Taylor, J. \& Corben, S. 2001. Narrative Evolution: Learning from Students Talk about Species Variation. International Journal of Artificial Intelligence in Education, 12:100-123.

Lunde-Whitler, J.H. 2015. Paul Ricoeur and Robert Kegan in Unlikely Dialogue: Towards a Narrative-Developmental Approach to Human Identity and its Value for Christian Religious Education. International Journal of Philosophy and Theology, 19(2):292-316. 
McQuiggan, S.W.; Rowe, J.P. \& Lester, J.C. 2008. The effects of empathetic virtual characters on presence in narrativecentered learning environments. In: M. Burnett, M.F. Costabile, T. Catarci, B. de Ruyter, D. Tan, M. Czerwinski \& A. Lund (eds.), Proceedings of the $26^{\text {th }}$ Annual SIGCHI Conference on Human Factors in Computing Systems. New York: ACM Press. pp. 151 1-1520. https://doi. org/10.1145/1357054.1357291

Miedema, S. \& Roebben, B. 2008. The two contested concepts of culture and tradition in religious education. Religious Education, 103(4):480-492. https://doi. org/10.1080/00344080802250800

Nelson, A. 1997. Imagining and critical reflection in autobiography: An odd couple in adult transformative learning, Adult Education Research Conference, Paper 33(6). [Online]. Available: http://newprairiepress.org/ aerc/1997/papers/33

Pargament, K.I.; Exline, J.J. \& Jones, J.W. 2013. APA handbook of psychology, religion, and spirituality: Context, theory, and research. Vol. 1. Washington, DC: American Psychological Association.

Polkinghorne, D. 1988. Narrative knowing and the human sciences. Albany, NY: State University of New York Press.

\section{Porter Abbott, H. 2002. The Cambridge} Introduction to Narrative. Cambridge: Cambridge University Press.

Prensky, M. 2001. Digital natives, digital immigrants. On the Horizon, 9(5): 1-6. https://doi. org/10.1108/10748120110424843

Rich, Y. \& Cinamon, R. 2007. Conceptions of spirituality among Israeli Arab and Jewish late adolescents. Journal of Humanistic Psychology, 47:7-29. https://doi. org/10.1177/0022167806291324

Ricoeur, P. 1984. Time and Narrative I. Chicago: The University of Chicago Press. https://doi.org/10.7208/ chicago/9780226713519.001.0001

Ricoeur, P. 1990. Life in Quest of Narrative. Teoksessa David Wood (toim): On Paul
Ricoeur. London and New York: Routledge. pp.20-33.

Ricoeur, P. 1992. Oneself as Another. Chicago: The University of Chicago Press.

Ricoeur, P. 2005. Hermeneutics and the human science. 17th Edition. J.B. Thompson (transl \& ed.). Cambridge, MA: Cambridge University Press.

Roebben, B. 2009. Seeking sense in the city: European Perspectives on Religious Education. Berlin: LIT Verlag.

Sallquist, J.; Eisenberg, N.; French, D.; Purwono, U \& Suryanti, T. 2010. Indonesian adolescents' spiritual and religious experiences and their longitudinal relations with socio-emotional functioning. Developmental Psychology, 4:699-716. https://doi.org/10.1037/a0018879

Steiner, K.L.; Pillemer, D;B.; Thomsen, D.K. \& Minigan, A.P. 2016. The reminiscence bump in older adults' life story transitions. Memory, 22:1002-1009. https://doi.org/10.1080/096 58211.2013 .863358

Taylor, C. 1989. Sources of the Self. Cambridge UP: Cambridge.

Taylor, C. 1995. Philosophical Arguments.: Cambridge, MA: Harvard University Press.

Vargas, L. 2006. Transnational media literacy: Analytic reflections on a program with Latina teens. Hispanic Journal of Behavioral Sciences, 28(2):267-285. https://doi. org/10.1177/0739986305285823

Weber, S. \& Mitchell, C. 2008. Imaging, keyboarding, and posting identities : young people and new media technologies. In: D. Buckingham (ed.), Youth, identity and digital media. Cambridge: MIT Press.

Wertsch, J.V. 1998. Mind as action. New York: Oxford University Press.

Zhao, K. \& Biesta, G. 2012. The Moral Dimension of Lifelong Learning: Giddens, Taylor, and the Reflexive Project of the Self. Adult Education Quarterly, 62(4):332-350. https://doi.org/10.1177/0741713611411176 


\section{Introduction}

Meaning-making through film takes place in everyday life and in the flow of movies and fictional storytelling (Axelson, 2008; Plantinga, 2009; Cloete, 2017). Theologian scholar, Anita Cloete, makes an important observation that film has an extra-ordinary capacity to tell us stories about important themes in life, like love, hope, death, good, evil, violence and peace. Film is attractive to people of different age groups. Movies tell us stories with which we can associate. It is also accurate to claim that film engages us as viewers as it relates to our personal stories, stories of the community we belong to and the world we live in (Cloete, 2017:1). This statement is supported by empirical audience research about fiction film engagement (Marsh, 2007; Axelson, 2008; Axelson, 2017; Oliver \& Hartmann, 2010). Film is a powerful resource. Sometimes it has the capacity to capture important life issues in a way that audiences can apply to their own real-life situations. Case studies highlight films' ability to touch people more deeply, especially when oriented towards personal values, hopes, conflicts and dreams, as well as critical questions about the surrounding world, mainly according to two dominant categories: ideas about ourselves and ideas about our society (Axelson, 2008). However, certain conditions seem to frame the cinematic experience for it to have an existential saturated appeal. In this chapter, I give an example of how it works and also theoretically discuss the conditions which seem to be necessary for the spectator to engage in this way.

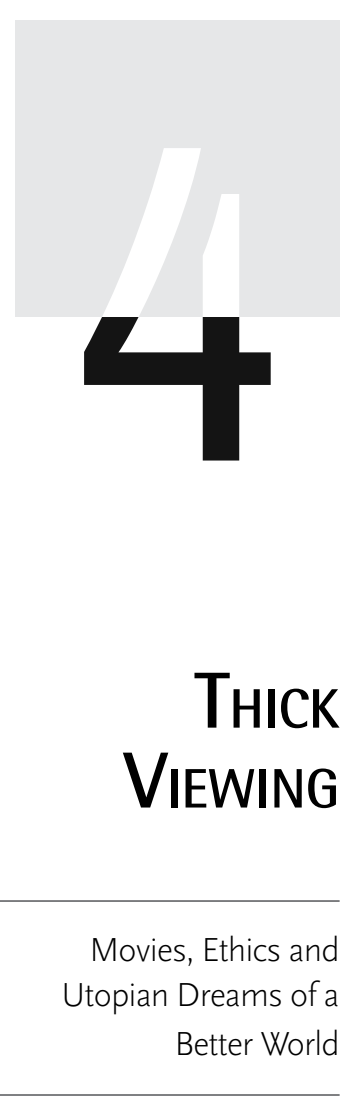

Tomas Axelson 


\section{Theoretical Prism}

In short, for engagement to occur, an individual needs to be involved both cognitively and affectively, creating a striking responsive chord, a deep response with an emotional evaluation, generating a multilayered interpretative process which I argue should be labelled "thick viewing" (Axelson, 2014; Axelson, 2017). In film moments of this kind, film viewers are absorbed and transported into the narrative - an intra-text. Simultaneously, they are deeply engaged in extra-textual references, testing the narrative for larger significance in profoundly idiosyncratic and personal ways, dealing with their own specific conflicts and spiritual aspirations in life and creating transformation (cf. model outlined below). Two specific dimensions will be dealt with more extensively and theoretically developed in an attempt to understand why a viewer is moved by a film: firstly an ethical dimension (Zillman, 2005); and secondly a utopian dimension (Johansson, 2002).

The chapter ends with a word of warning. It is easy to (mis)use a film for pedagogical ambitions to promote emotionally charged and interesting discussions in school or in church. But it is a tricky task to arrange a successful setting for this to happen. Processes of identification are multilayered and an emotionally complex phenomena, which sometimes take place and sometimes do not. That is why you have to be cautious when trying to use film as a tool to achieve certain educational objectives, be it in church, school or elsewhere. The aesthetic power of film is unpredictable, and you never know if the viewers are glued to the screen for the same reasons as you are (cf. Axelson, 2018).

\section{Being Moved by Movies - a Female Viewer and Amelie from Montmartre (2001)'}

Picking an interesting example of a spectator's engagement in a film, creating a considerable cinematic impact, I will describe a young woman, Linda, who is in her late 20's, and her involvement in the movie Amelie de Montmartre (2001). The example of Linda is taken from the Swedish research project Spectator engagement in film and utopian self-reflexivity. Moving Images and Moved Minds. ${ }^{2}$ The project was designed to develop and assess a theoretical framework to analyse viewers' responses to cinematic narration and to better understand how viewers are deeply moved by movies. The overarching aim was to broaden our scholarly understanding of the use of fiction in people's lives. The main research questions were: How does engagement in fiction films affect spectators' meaning-making processes regarding

1 The film will be called Amelie in short in the following.

2 Financed by The Swedish Research Council 2011-2014. 
more profound and long-lasting ideas about themselves and society? And more specifically: What kinds of thoughts and feelings are articulated when viewers get the chance to talk about their favourite films and significant sequences in these films? More than 300 young adults, mostly between 20-35 years old, answered a questionnaire about their film habits, film preferences and also how many times they estimated they had watched some of their most cherished films. A group of ten individuals were then selected for in-depth interviews about their all-time favourite films. Linda was one of these ten. The movie Amelie (2001) proved to be one of the recurring favourite movies in the larger group. A small number of respondents in the project estimated that they have seen the movie 20 or 30 times, and in one case nearly 50 times.

\section{Synopsis Amelie from Montmartre (2001)}

As a child Amelie was diagnosed by her father as having a weak heart. She lives a careful, somewhat withdrawn life. She has a vivid, colourful imagination, which she uses to overcome her loneliness, but also to do well. She lives her life amidst other people on the margins of social life, people whom she assists in critical moments. Amelie also tries to communicate with her father without success. She dreams of finding love in the outside world. She searches for it with the help of a mysterious photography machine, creating a marked path for a young man she has fallen in love with. Friends around Amelie support her struggle for a warmer world and support her in the belief that love is even for her.

\section{Linda (29) and her Dream of a More Beautiful World}

Linda is 29 years old and currently works as a professional in the broadcasting business. She has always watched a lot of films. She also has the habit of viewing movies she loves repeatedly. She is one of the few viewers in the study who claimed to have seen Amelie more than 30 times. The movie Amelie gives her access to a world she wishes to be part of, and she called the movie her own hideaway or haven which is there for her exclusively. It is a story that engages her emotionally overwhelmingly. "It is almost like a magical place. Amelie, it contains some form of magic that I miss as soon as the movie ends. So then I just want to ... again. I think the record for me with Amelie, is that I've seen it three times in a row in one day without interruption."

She wants to be completely alone in order to fully focus on the movie. "It is all about being dragged into this world." It does not engage her to this extent when others accompany her while watching, as has happened occasionally. The presence of other people has a negative impact on her ability to get 'into' the film. 


\section{To look upon the world with the eyes of enchantment}

What is it in Amelie that brings her back to this story again and again? "Well, I feel just happy, from the inside out." Linda believes the story is enchanting. Amelie is a person who had a troublesome childhood. With the help of her inner world, her imagination, Amelie manages to carry on despite being quite lonely as a child. "I can understand her need for a fantasy world and that her fantasy world is so present all the time." The movie is also funny, "and filled with heart". Amelie does not see the world as grey and cold, instead she sees "these small colourful moments which are everywhere". Linda can easily relate to this as someone for whom her fantasy world was always close at hand as a child. She could always create her own small world, for example when she and her parents were invited somewhere and she had to manage on her own.

\section{Amelie's goodness and originality and a wish that more people were like her}

It is not identification with the character of Amelie in a narrow sense that captures Linda, but rather the larger vision of life that the entire film portrays, which she finds compelling. "It's kind of an image of my own world. I identify myself with the story in its entirety. It is not something that exists... in the movie only. It is something else. That's why it feels like a haven. A deep sense of ... mirroring something I share. I am thinking ... reflecting ... and meditating ... before ... during ... and after."

Linda explicitly hopes that we could all be more inspired by the Amelie character, a good person who dares to do things in an unconventional way, with a lot of heart and courage. "She acts like a guardian angel in people's life and takes care of everyone else. And I wish there was a bit more of that in the world." Linda described how well the film corresponds with her own vision of a different kind of life, a life where we stand up for each other and always help people when they are treated badly.

\section{Scene Selection. Amelie Plays a Trick on the Vegetable Merchant [00:51:14]}

As part of the method in the project, the individuals chosen for personal interviews were asked to talk about their favourite film. I asked the respondents to pick one or two sequences which touched them the most in the whole movie. It was an open question to which they could respond by talking about a scene that moved them in a positive or negative way. Eight out of ten respondents happened to pick scenes that moved them positively, and Linda was a typical example of that. The scene Linda enjoys most of all in the whole movie is when Amelie intervenes 
and playfully reprimands the vegetable merchant after his scornful treatment of his helper Lucien, a simple, gifted, but very kind young aide in the fruit store. "He's really mean to him. "Amelie witnesses the merchant's mockery of Lucien. She enters the merchant's apartment, using a duplicate door key. "I love this when she has entered his apartment. She gets in control and rules the situation. There are so many moments here, easy to relate to. And I understand the feeling of it."

Amelie replaces the merchant's toothpaste and shoe cream, switches the position of two door handles, changes the time on the alarm clock, and fiddles with the merchant's shoelaces. Later that night the merchant experiences the effects of Amelie's small traps. "She puts up revenge in a harmless way. She does not really harm, but she gives him pay back." I asked if it is important that it is a mild punishment and that no one is harmed by her tricks. "Yes, because otherwise she would have been mean. But she is not." Linda had just watched a television show where an elderly woman received an award for having intervened and stopped a knife fight between three men. The woman was Linda's hero. The old woman had stamina, showed courage and countered a general passivity that Linda believes dominates, a non-action that is common in society. But Amelie reacts and takes action. "Amelie, she acts like Karma. Rewards those who deserve to be rewarded and punishes those who deserve to be punished. She fixes the love letter to the woman who lives in the past. Amelie creates a happy bubble! "

Linda actually wants real life to be much more like the action surrounding Amelie. "You want to do something. But normal people do nothing. It is often this typical Swedish phenomenon to look the other way. I don't like that. It is better to say"... "Hey, what are you doing?"

Linda tried to capture what it is in this movie that makes her feel all these positive feelings and thoughts and why she has watched it so many times. To begin with, the film is very funny and much more daring than a typical Hollywood film. It is dramatic, with rapid editing and a lot going on in the narration at the same time. "It is playful. It has a thrilling selection of pictures. You're not sitting and looking at a standard Hollywood movie, you see that directly." She finds the narration in the movie is deeply satisfying. She claimed that the film goes beyond ordinary thinking in a limited sense. It is intense and wide open. "I am like totally ... dedicated. It is something else, something larger. I look into a fantasy... which partially is my own."

Linda's way of thinking about her movie experience expresses her own moral vision in life. "In many ways it is a wish that this would be more present in the world." Linda said she probably thinks more about these issues because she feels so heavily influenced by this film. Finally, Linda tried to put her finger on what it is that 
captivates her so completely about the movie Amelie. "To feel exactly the feeling about the things going on in the story, but it's also something else ... something deep down in the story. I'm just happy in my soul." Linda thought she expressed herself very vaguely about her experience of the movie as she tried to pinpoint it. She tried to reach out to something that is obviously difficult to formulate.

\section{Theoretical Interpretation}

What conclusions can be drawn from this example? Empirical research about fiction film engagement provides good reasons to support a conclusion that film is a resource which sometimes has the capacity to capture and mirror profound life issues for audiences (Marsh, 2007; Axelson, 2008; Oliver \& Hartmann, 2010). Recent case studies also show how and in what way audiences are able to transfer film content, testing it against their own real-life situations (Axelson, 2014; Axelson, 2017). Something happens in these rare moments when cinema-goers are deeply emotionally involved in a movie. But what exactly?

Let me start with the model I created as result of the research project. Certain conditions seem to frame the cinematic experience for it to have an existentially saturated appeal. The individual needs to be involved both cognitively and affectively, creating a deep response of emotional evaluation, generating a multilayered interpretative process which I label 'thick viewing'. The film interpretation model below describes the process which creates ideal conditions for personal and idiosyncratic interpretations of an audiovisual representation.

The film gives an input (1) as 'sujet' ${ }^{3}$ and initiates a meaning-making process in the viewer (2). An emotional evaluation (3) develops, consisting of affects (4) and cognitions (5) combined. A fabula (6) is constructed by the viewer. ${ }^{4}$ Practically all movie-goers are occupied with the next step, an interpretation of the intra-text narrative (7), what is actually happening in the film. Finally, and most important theoretically for this chapter, some viewers are simultaneously deeply engaged in extra-text references as external critique, testing the narrative for a larger significance (8). My empirical contribution to film theory is that this is done in uniquely idiosyncratic and personal ways, involving the spectator's own conflicts and spiritual aspirations in life.

What is actually seen and heard on the screen, as bits and pieces of an ongoing story unfolding.

4 The intended 'story' behind the presented selection of events on the screen. 


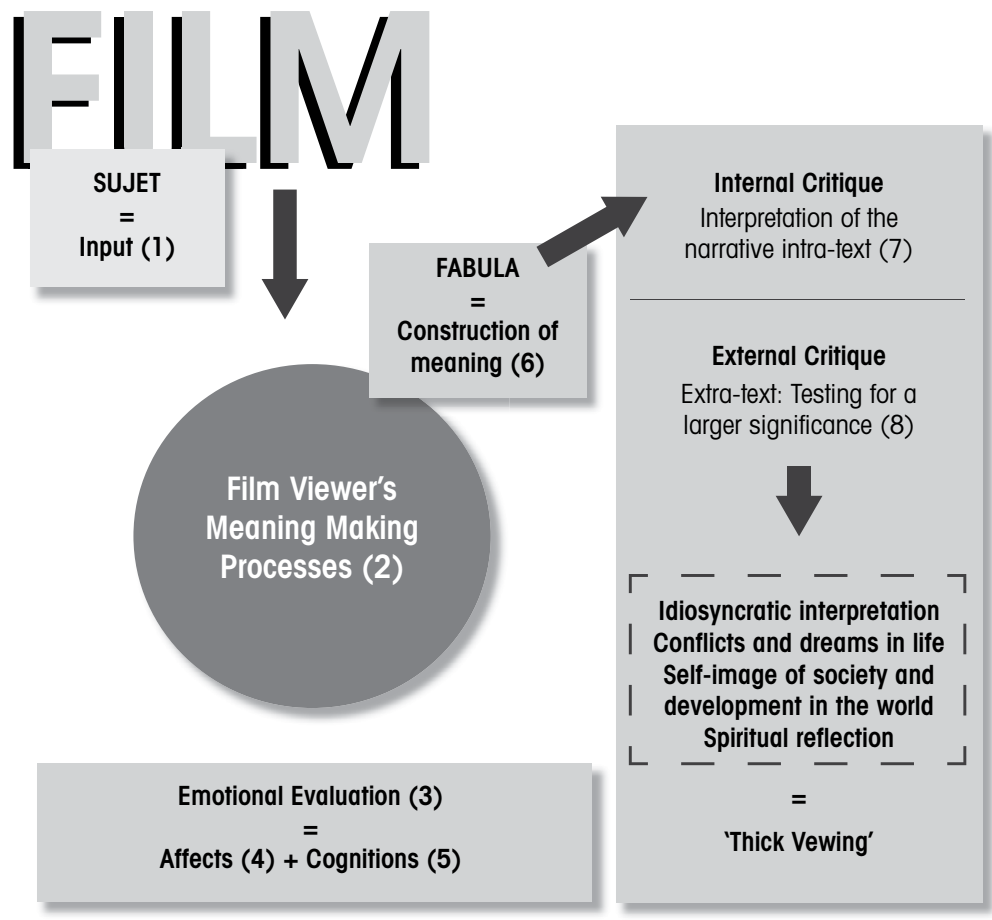

Figure 4.1 A schematic figure of meaning-making processes while watching films, underlining the combination of affect and cognition, as well as a combination of intra-text and extra-text critique (Model the author's own)

In this case, the following happens: Emotionally satisfying scenes are processed through a network of private associations and previous experiences, creating a personally relevant, idiosyncratic response in the individual, in which basic emotions and abstract thoughts are intertwined, generating depth in interpretation, evoking personal memories and fostering deep resonances which match the viewer's own life situations (Grodal, 2009; Axelson, 2014; Axelson, 2017). It can also be described as an emotional evaluation of life issues depicted on the screen, producing an ongoing movement from the narrative - intra-text - to viewers' own real-life issues outside the film - extra-text - in a seamless flow between the film's narrative and the individual's own life. In these moments, the film becomes a psychological resource that provides a means to be transported into the narrative, for a possible processing of the viewer's own life processes, where transformation can take place (Vaage, 2009; Axelson, 2014:149). 


\section{Deep Meaning}

What is this deeper meaning though? Cognitive scholar, Peter Gärdenfors, labels humans as "the meaning-making animal" (2006:151). We, as humans, are always dealing with several levels of meaning-making, ranging from simple interpretations of everyday details to the quest for the meaning of life. This second abstract and more in-depth creation of meaning is what this chapter is about, fiction film's ability to touch people's profound aspirations and sentiments about life. Engaging movie experiences invite viewers to interact with important personal and private life issues (Plantinga, 2009; Oliver \& Hartmann, 2010; Axelson, 2015). Several concepts have been suggested to capture the complex interplay between affects, cognition and emotions when individuals respond to fictional narratives on a deeper level. Theologian and film researcher Robert K. Johnston labels this kind of multilayered mix of affects and cognitions which reach our spiritual sentiments as "transformative viewing" (2007:305) or "deepening gaze" (2007:307). Philosopher Mitch Avila proposes "high cognition" (2007:228) and Casper Tybjerg "higher meaning" (2008:60). Torben Grodal refers to it as "feelings of deep meaning" (Grodal, 2009:149). Craig Detweiler adopts "thick description" (2007:47), and Kutter Callaway alters it slightly to "thick interpretations" (Callaway, 2013:203). Inspired by Detweiler and Callaway, I advocate 'thick viewing'. But what is 'thick viewing' and how can Linda and her experience of Amelie shed some light on this description?

\section{A Utopian Dimension - Visionary Thoughts Fueled by Utopian Affect}

Firstly, I would like to stress the importance of being able to dream about an alternative world with the help of fiction. Social psychologist Thomas Johansson talks about "the extended self and humans" ability to extend the mind into mediatised fantasy worlds (Johansson, 2002:38). He highlights the importance that mediated stories may have for our fantasy when we make excursions into fiction film and envision alternative ways of living. "The media provides everyday life with images, fantasies and stuff that dreams are woven by" (Johansson, 2002:169). Johansson underscores the function of fictional content for individuals in today's society, creating room for utopian thinking. "In many cases TV and film can offer alternative visions for life for all kind of possible and impossible lifestyles and behaviours, as utopian fragments." (Johansson, 2002:171)

I think that this is illustrated to a high degree by the example of Linda and her intense relationship with the movie Amelie. In Amelie, Linda sees an ideal vision of how life could be when it is beautiful, creative, artistic, humanistic and when people care for each other with empathy and sensitivity. The film contains a strong ideal dimension 
for Linda. Linda illustrates what could be labelled as 'utopian reflexivity', where a fictional world happens to fit a specific spectator's mind like a glove, enabling mental excursions into a fantasy of a different kind of world (Johansson, 2002). The film Amelie gives Linda impulses about what her dreams of an ideal life could look like. This empirical finding in my research is reiterated elsewhere. The American film scholar Barbara Klinger gives examples of how dreams of a different world function when she interviewed young women and their involvement in the Lord of the Rings trilogy as case studies. These three films are also, incidentally, some of Linda's favourite movies. Barbara Klinger notes that the trilogy manages to create a dream world that allows viewers to move into an alternate utopian universe.

They find hopes and wishes and a sense that things could be better than life as it looks today. As one viewer expressed it, "the movie captured well the importance of friendship, perseverance, love and courage ... qualities that are all too often absent in today's contemporary movies. It appeals to the optimistic romantic in me."

Klinger, 2008:81

Both the Lord of the Rings trilogy and Amelie contain visionary ideals that create a strong commitment in cinema audiences, with a combination of a given content and an emotional, affective devotion. Klinger describes it as a confirmation of important spiritual beliefs, "fueled by utopian affect" (Klinger, 2008:82). This is a good description of Linda's attitude towards Amelie.

I think it is also highly relevant that, when Linda described her experience of Amelie, the protagonist, Amelie, is seen as a character who activates what some psychologists of religion call "messianic hope". There are certain people in the world who manage to create a messianic atmosphere around them (Bergstrand, 1990). These unique individuals actually live their lives according to a messianic vision. They do not wait until the world has developed into a better place; instead they start with what is at hand in their own earthly life. These people offer something appealing and attractive by living as if the reality they reach out for and wish for, already exists around them.

They become carriers of "the Messianic hope" in humanity. They live as if the long-awaited reality already is real. With their lives, they create zones of liberation and reconciliation in the world.

Bergstrand, 1990:45

Which is what Amelie does. The world which Amelie - and Linda - wish to be in, is actually taking shape in accordance with this messianic hope. Or as Linda put it: "Amelie creates a happy bubble." In this regard Amelie as a screen character 
can also be interpreted as a female cinematic Christ figure. ${ }^{5}$ This perspective could of course be developed extensively, but this is not the task in this chapter. In this context, with a focus on what is actually expressed by the spectator, I believe it is important to note Linda's use of a popular Buddhist concept when she described Amelie's behaviour: "Amelie, she acts like Karma."I do not know if it is a desacralised use of the term by Linda, but it does not really matter in this context. It adds to her emotional commitment to the movie.

\section{An Ethical Assessment Dimension}

Secondly, it is important in terms of my interview with Linda to clarify the phenomenon where thoughts and basic emotions are allowed to unify with moral reasoning. Linda exhibited a typical example of a movie consumer expressing ethical thinking in accordance with psychologist Dolf Zillman's work on story-telling and morality. Zillman emphasises the need for balance between perceived wrong-doings and a gut feeling of apt punishment for creating maximum satisfaction for a consumer of a drama.

Transgression during conflict and punishment during resolution must be roughly commensurate for the punishment to be morally sanctioned and deemed emotionally satisfying. Punishments that fall outside the latitude of sanction leave the respondents' sense of justice disturbed, which ultimately does diminish the enjoyment of resolution.

Zillman, 2005:175

Dolf Zillman underscores a conclusion that is valid for Linda's deep engagement in Amelie. "The emotions evoked by the resolution of conflict in drama are undoubtedly pivotal to the enjoyment of cinematic narratives." (Zillman, 2005:175) In his theory of basal morality in drama appreciation, Zillman sheds further light on these phenomena. "Recipients bring their idiosyncratic morality to the screen, sanction or condemn witnessed actions and agents in accord with it, and then experience emotions as a result of their assessment." (Zillman, 2005: 176) In his experiments, he showed how young viewers draw cognitive conclusions about protagonists' moral character which in turn create a readiness to accept and approve the doings of this character. He showed how cognitive consideration comes first and affective disposition after. It is this response that Linda displayed when she talked about how her engagement with the Amelie character is amplified by the empathy Amelie shows to people around her. Linda's evaluation of Amelie as character comes first, leading her to increased feelings of sympathy for Amelie as a result of her moral

There is a massive literature on both Jesus films and what is called cinematic Christ-figures, which I will not develop further here (see for example Baugh, 1997; Tatum, 1997; Fraser, 1998; Deacy, 2001, etc.). 
judgement and her ethical cognitive appraisal of Amelie as a character. As Linda illustrates, thoughts and basic feelings (affects) seem to be condensed into a special kind of compelling totality in really deep movie experiences, a complex and multilayered unit, linked both to the fundamental values of the individual combined with an aesthetic euphoria charging them. This is the core content of 'thick viewing'.

'Thick viewing' refers to the process when a spectator tests fiction for a larger significance in unpredictable, playful and idiosyncratic ways, creating condensed moments of intensified engagement in film viewing, mobilising the spectator's interpretative skills in toto, ranging from affect to high cognition, creating emotional evaluations and complex meaning-making and mobilising the respondent's total world view system. The concept complements visual hermeneutics and the development of philosophical top-down claims of what happens in the field of visuality. 'Thick viewing' is a bottom-up concept and attempts to give credit to what flesh-and-blood spectators express, with all the nuances of different layers of meaning-making.

It is impossible to fully translate movie experiences into only a linguistic discourse, as is often done, especially by theologians, trained exegetics as they may be. Linda's experience supports scholar Daniel Frampton's development of a new word, "filmosophy". He claims that we are approaching another way of thinking anchored in film's moving images, a form of theoretical thinking for which we have not yet found the right conceptual apparatus, combining affect and cognition as key in the film experience (Frampton, 2006:166). This is partly in line with what American film scholar Carl Plantinga addresses when he theorises about film's ability to help us work our way through strong emotions (Plantinga, 2009).

\section{Conclusion}

As an audience researcher involved in film research with flesh-and-blood spectators for more than a decade, my conclusion is that we are dealing with unpredictable processes. Individuals seem to relate to all kinds of films as a play with metaphors processing different life issues, private conflicts and dreams, often based on movies viewers happen to see in the course of everyday life. Suddenly, a scene with a certain gist or narrative feeling, captures something personally important.

For Linda the experience of the film Amelie is charged with an emotional impact of unmissable magnitude. It is a movie moment similar to Nancy Ammerman's fruitful understanding of art's capacity to generate meaning-making. Charged perceptions of meaning can be triggered by works of art, with individuals "stepping out of the ordinary business of life, stretching the mind and imagination", evoking awe and 
a quest for meaning and purpose in life (Ammerman, 2013:269). This aspect of films as part of our vernacular life, sometimes even embedded in our bedrooms, needs to be noted. Films are a relaxing and enjoyable part of our daily life, which, at the same time, allow us to deal with important life issues. "A work of art acts like a playground for the mind, a swing or a slide or a merry-go-round of visual or aural or social pattern", says film scholar Boyd (2009:15). In that moment, we can step away from the demanding activities of everyday life and contemplate our lives.

Narrative fiction, in particular, helps us to understand ourselves, to think - emotionally, imaginatively, reflectively - about human behaviour, and to step outside the immediate pressures and the automatic reactions of the moment.

Boyd, 2009:208, in Plantinga, 2011:39

The pleasure of these activities should not be dismissed. Susan Best underscores how involvement in aesthetics needs to be recognised. "Aesthetics is not simply an embarrassment for cultural theory; it contains some of the clues for rethinking the gaze, visual pleasure and affective engagement with art." (Best, 2007:509)

A word of caution, however: it is problematic to set up a pedagogical situation where there is a clear prospect of the direction of young people's meaning-making through film. Didactic research about the use of fiction film to develop pupils' historical thinking, as well as research on church initiatives to develop emotional responses about life issues, point to the difficulties of doing so (Deldén, 2017; Axelson, 2018). You really cannot know in advance what kind of affects and cognitions will be activated by the powerful medium of audiovisual storytelling. For example, I participated in a project called "Video as a Medium for Restorative Experiences", where a supposedly consoling and contemplative short film was shown in the hope that it would facilitate life crisis situations for a group of women going through experiences of loss and grief. The participants reacted strongly, displaying a range of negative reactions, from mildly irritated non-engagement to open anger towards the appeal of the film (Axelson, 2018). This took the research group by surprise and supplied new empirically anchored answers about the difficulties of deciding beforehand what people are about to experience, affectively and cognitively, through a film. This is in line with Anita Cloete's accurate remark, "The focus on the viewer or the audience means that there is no single prescribed message from the film, but various ways in which the same film could be understood and experienced" (Cloete, 2017:4).

As Daniel Frampton puts it, film communicates directly with a non-linguistic part of our mind (2006:164). This is what makes movies emotionally powerful. At the same time, movies invite their audiences to think about the world and our different 
trajectories through life. There is empirical support for the conclusion that films have the power to change us, or at least some of us. Movies "may add new, relevant information to viewers' self-narratives, broaden their horizons, show them what is really important in their lives" (Oliver \& Hartmann, 2010:132). Cinematic narratives embedded in everyday life, provide audiences with stories with the potential for emotionally anchored normative criticism, as well as enchanted dreams about life and the world as it could be. Movies have the potential to facilitate contemplations of utopian aspects of life, as well as moral concerns, as Linda's views on Amelie indicate. Film is entertainment. Yes, but at the same time, now and then it has the capacity to mirror audiences' most profound ethical views and utopian dreams of an alternative world.

\section{Bibliography}

Ammerman, N. 2013. Spiritual but not Religious? Beyond Binary Choices in the Study of Religion. Journal for the Scientific Study of Religion, 52(2):258-278. https://doi.org/10.11 1 1/jssr. 12024

Axelson, T. 2008. Movies and Meaning. Studying the Audience, Favourite Films and Existential Matters. Particip@tions: Journal of Audience and Reception Studies, 5(1).

Axelson, T. 2014. Förtätade filmögonblick. Den rörliga bildens förmåga att beröra. Stockholm: Liber.

Axelson, T. 2015. Vernacular Meaning-Making. Examples of narrative impact in fiction film: Questioning the 'banal' notion in mediatization theory. Nordicom Review. Göteborg: Nordicom.

Axelson, T. 2017. Movies and the Enchanted Mind. Emotional Comprehension and Spiritual Meaning-Making Among Young Adults in Contemporary Sweden. Young. Nordic Journal of Youth Research, 25(1):8- 25. Los Angeles: Sage Publications.

Axelson, T. 2018. The Dark Night of the Soul: Art film, bereavement and unsatisfied audience responses. Journal of Religion, Media and Digital Culture. 7(2):137-157. Leiden: Brill.

Avila, M. 2007. From Film Emotion to Normative Criticism. In: R.K. Johnston (ed.), Reframing theology and film: new focus for an emerging discipline. Grand Rapids, Mich. Baker Academic.

Baugh, L. 1997. Imaging the divine: Jesus and Christ-figures in film. Lanham, Md.: Sheed \& Ward.

Bergstrand, G. 1990. Från naivitet till naivitet: om James W Fowlers modell för trons utveckling. Stockholm: Verbum.

Best, S. 2007. Rethinking Visual Pleasure: Aesthetics and Affect. Theory \& Psychology, 17:505-514. Calgary: Sage Publications. https://doi.org/10.1 1 177/0959354307079295

Boyd, B. 2009. On the Origin of Stories: Evolution, Cognition, and Fiction. Cambridge, MA: Belknap Press.

Callaway, K. 2013. Scoring transcendence: contemporary film music as religious experience. Waco, Tex.: Baylor University Press.

Cloete, A.L. 2017. Film as medium for meaning-making: A practical theological reflection. HTS Teologiese Studies/Theological Studies, 73(4). https://doi.org/10.4102/hts. v73i4.4753

Deacy, C. 2001. Screen Christologies: redemption and the medium of film. Cardiff: University of Wales Press.

Deldén, M. 2017. Perspektiv på historiefilmslitteracitet: en didaktisk studie av 
gymnasieelevers historiska och emotionella meningsskapande i mötet med spelfilm.

Diss. Umeå: Umeå universitet.

Detweiler, C. 2007. Seeing and Believing: Film Theory as a Window into a Visual Faith. In: R.K. Johnston (ed.), Reframing theology and film: new focus for an emerging discipline. Grand Rapids, Mich.: Baker Academic.

Frampton, D. 2006. Filmosophy: [a manifesto for a radically new way of understanding cinema]. London: Wallflower.

Fraser, P. 1998. Images of the passion: the sacramental mode in film. Westport, CT: Praeger.

Grodal, T. 2009. Embodied visions: evolution, emotion, culture, and film. Oxford: Oxford University Press. https://doi.org/10.1093/ acprof:0so/9780195371314.001.0001

Gärdenfors, P. 2006. Den meningssökande människan. Stockholm: Natur och kultur.

Johansson, T. 2002. Bilder av självet: vardagslivets förändring i det senmoderna samhället. Stockholm: Natur och kultur.

Johnston, R.K (ed.). 2007. Reframing theology and film: new focus for an emerging discipline. Grand Rapids, Mich.: Baker Academic.

Klinger, B. 2008. What Do Female Fans Want? Blockbusters, The Return of the King and U.S. Audiences. In: M. Barker \& E. Mathijs (eds.), Watching the Lord of the Rings: Tolkien's World Audiences. New York: Peter Lang Publishing.

Marsh, C. 2007. Theology goes to the movies: an introduction to critical Christian thinking. London: Routledge.

Oliver, M.B. \& Hartmann, T. 2010. Exploring the Role of Meaningful Experiences in Users' Appreciation of Good Movies. Projections: The Journal for Movies and Mind, 4(2): 128-150. https://doi.org/10.3167/proj.2010.040208

Plantinga, C. 2009. Moving Viewers: American Film and the Spectator's Experience. Berkeley: University of California Press.
Plantinga, C. 2011 . Folk Psychology for Film Critics and Scholars. Projections: The Journal for Movies and Mind, 5(2):26-50. https://doi.org/10.3167/proj.201 1.050203 Tatum, W.B. 1997. Jesus at the movies: a guide to the first hundred years: revised and expanded. Santa Rosa, Calif.: Polebridge Press.

Tybjerg, C. 2008. Forms of the intangible: Carl Th. Dreyer and the concept of transcendental style. Northern Lights, 6:59-73. Bristol: Intellect. https://doi.org/10.1386/ nl.6.1.59_1

Vaage, M.B. 2009. Self-Reflection. Beyond Conventional Fiction Film Engagement. Nordicom Review, 2:2009. Gothenburg: Nordicom.

Zillman, D. 2005. Cinematic Creation of Emotion. In: J.D. Anderson \& B.F. Anderson (eds.), Moving Image Theory. Ecological Considerations. Carbondale: Southern Illinois University Press.

\section{Filmography}

Amelie de Montmartre. 2001. France: Claudie Ossard Productions.

Lord of the Rings trilogy. 2001-2002-2003. USA: New Line Cinema. 
An eye opener, a guideline, also a lifestyle because it shows you where you could have been today.

Respondent

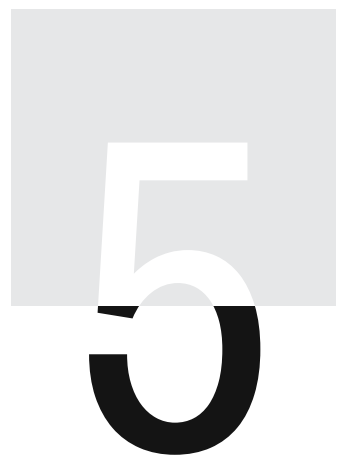

\section{Introduction}

Research indicates a resurgence of religion, especially through the medium of film. Research on the relationship between religion and media in general, and film specifically, is crucial in a time when it seems that institutional forms of religion are declining. Although theoretical reflection on film and religion is growing, there is still a lack of empirical work to substantiate/ validate the religious value of this form of media. This chapter will contribute in this regard by reporting on individual interviews with five young people between 18 and 35 years about their experiences when watching film and the value of films for them. The aim is to describe and analyse how participants utilise religious categories and knowledge to construct meaning from film, and whether they deduce some kind of moral guidance from film. The religious value of film will be discussed within the framework of popular culture and lived religion, arguing that popular culture provides a hermeneutical function whereby people can make sense of their experiences and life. The functionalist view of religion is applicable in the discussion.

\section{Motivation for the Study}

It is common knowledge that we live in a media saturated world and, due to the domestication of different forms of media, it is becoming increasingly

\section{ReLIGIOUS \\ FUNCTION OF FILM}

A Viewer's Perspective
Anita Cloete 
challenging to reflect on the impact thereof in a critical manner. Therefore, efforts to reflect on the seemingly obvious yet complex relationship between media and religion, are necessary. As a religious person myself and as a lecturer at a faculty of theology with a focus on youth in South Africa, a relatively religious country, it is of interest to me to understand what is perceived as religion today, especially among youth. I am also interested in how media as part of popular culture and lived religion is changing religion by fulfilling a religious role or function. Moreover, as a practical theologian, it is important to gain understanding of the contemporary role and function of religion, as well as the practices and actions of people in everyday life. The choice to reflect on film as a form of media is motivated by the fact that film has the ability to create experience and rewrite religious texts like no other medium. Furthermore, film tells stories with which we as individuals and societies can relate, opening our eyes and imaginations to new or alternative realities, and therefore has the ability to inspire us (Cloete, 2017; Axelson, 2017). Films also have a hermeneutical function, assisting viewers to make sense of their lives and aiding understanding of their communities and broader society. Practical theologian, Ganzevoort (2011), emphasises the public significance of religion from a cultural perspective. He argues that the media sphere is one where religion emerges in vibrant and innovative ways because, as a cultural space, media is loaded with religious themes and images (Ganzevoort, 2011:95). A cultural view of religion as part of popular culture focuses on content and experience, and therefore this chapter will move away from analysis of the film as text, to audience reception. Audience reception focuses on what happens to those who watch films. Put differently, audience reception attempts to respond to the questions of how viewers use or consume film, and how this fits with their worldviews and lifestyles. Empirical work is best suited to enable viewers to motivate their choices and articulate insights gathered in the process of watching film, and thus facilitate a process of reflection (Marsh, 2009:256).

I have previously argued that a viewer's perspective is of importance because meaning-making in a digital age is a negotiated process in which the viewer or consumer plays a central role (Cloete, 2017:4). Moreover, a viewer's perspective gives an indication of how people experience and view the religious value of popular culture, and, even more importantly, their view of the role of religion in their everyday life. The focus here is not on explicitly religious films, but rather on the often implicit religious significance that watching film may have for viewers. Religion is a multifaceted phenomenon and includes several aspects, like belief having sacred texts as foundation. Religion can also be defined in terms of what people do, in other words certain practices and rituals that adherents carry out. Another approach to describing religion, is what is regarded as sacred and how people relate to 
it. Finally, religion can also be understood in terms of its purpose or function for individuals and society (Mahan, 2014:6-7). A more precise working definition or understanding of religion in this chapter, is the notion of lived religion, referring to the fact that non-religious or not overtly religious practices like watching films, could have religious or moral significance (Cloete, 2017:2; Miller-McLemore, 2012). Although popular culture is difficult to define, here it is understood as what is popular with the masses as part of common life, and the broader framework within which lived religion functions.

This chapter could contribute to the understanding of the public significance of religion as produced, presented and framed by popular culture in contemporary society. Religion is one of the primary foci of practical theology. There is a need today to trace the sacred in all spheres of society. The media, and particularly film as medium, is such a cultural space where we can engage with the intersection between popular culture and religion in the everyday life of people. It is acknowledged that media is not neutral and therefore has the power to mediate information and values, but this study would like to emphasise that viewers of film are not passive consumers. To the contrary, viewers engage with film against the background of their contextual life experiences, which include religious views and knowledge. Therefore, it is helpful to take note of the different models that can be identified to describe the interaction between film as medium and viewers. Marsh (2009:258-260), referring to the work of Janet Staiger (2005), discusses at least three models that describe the engagement between media and the users thereof. The first is the education model, according to which people gather new knowledge. The second is the reinforcement model which suggests that media often reinforces existing dominant religiousand world-views. While, according to the last model, the mediation model, media interacts with users cognitively and sensationally on various levels. Although all the activities central to these different models of engagement with film may be present most of the time, the third model, the mediation model, is most relevant to the focus of this work, as it not only focuses on content, but also on the experience created by watching film. This experience not only involves a cognitive element, but also an embodied experience in which emotions are a central element in the process of meaning-making (Grant, 2003:125). These models underscore the power of engagement with the media, because both the media and the audience have a certain level of power in the multifaceted process of meaning-making. The media has the power to captivate the user, but at the same time the viewer/user has the power to resist or to actively use the media to construct a world-view or for recreational purposes. Clearly the engagement between media and users and meaning-making is not linear, but rather a very complex process. Therefore, it necessitates empirical work to facilitate structured reflection to dissect the complex interaction between media and users thereof. 


\section{Methodology}

The data collecting method used was basic individual interviews. The unit of analysis was youth between 18 and 35 years old from any faith tradition who are interested in the topic. I utilised my personal networks to identify possible respondents and used snowball sampling to identify more respondents. Five of six respondents (two male and three female) participated in individual interviews. Two interviews took place at the residences of the participants and I met three others at a coffee shop. All participants are from areas in Cape Town. The interviews lasted between 30 and 45 minutes. Ethical clearance was obtained from the Ethics Committee of Stellenbosch University. Before the interviews, the focus of the study, interviewees' rights and ethical implications were explained, after which participants signed consent forms. Since these are case studies, the findings cannot be generalised, but give some indications of the religious value of films for youth. Furthermore, the findings present themes that can be explored further through follow-up empirical studies to establish how film as a very prominent form of media is fulfilling a religious role in especially the lives of young people.

\section{Interview Guide}

\section{Background information}

\section{Questions}

1. What kind of films do you like to watch? (For example Drama, Love stories, Fictional, Religious, ect.)

2. Do you have a favourite movie/s? Tell me why it is so special to you?

3. Many movies focus on the fight between good and evil (for example Star Wars and Harry Potter). In the light thereof, would you say movies could give some form of moral guidance on how to or how not to live your life? (What is wrong and what is right)

4. Did any story in a film inspire you do something or assist you with difficult decisions in your life?

5. How would you describe your experience of watching a film?

6. What role does watching films play in your life? (Meaning of films for you) 
Table 1 Background information of participants

\begin{tabular}{|l|c|c|c|}
\hline \multicolumn{1}{|c|}{ Gender/ Pseudo names } & Religious affiliation & Age & Language \\
\hline Male (Shiraad) & Islam & 25 & English \\
\hline Female (Fatima): married & Islam & 21 & English \\
\hline Female (Estelle) & Christian & 21 & Afrikaans \\
\hline Female (Christine) & Christian & 25 & English \\
\hline Male (Lionel): married & Christian & 24 & Afrikaans \\
\hline
\end{tabular}

Table 2 Films mentioned by participants during the interviews

\begin{tabular}{|c|c|c|}
\hline Name of film & Genre & Gender \\
\hline Grave dancers & Horror/Supernatural & Male \\
\hline Freddie versus Jason & Thriller & Male \\
\hline Annabelle & Mystery/Thriller & Male \\
\hline Harry Potter & Series/Fantasy & Male \\
\hline Star Wars & Series/Science Fiction & Male \\
\hline Fast and the furious & Series/Action & Male \\
\hline Blade & Thriller/Fantasy & Male \\
\hline Underworld & Series & Male \\
\hline Titanic & Drama/Disaster & Female \\
\hline Notebook & Drama/Romance & Female \\
\hline Four corners & Drama/Fantasy/Crime & Female \\
\hline A Cross to bear & Drama & Female \\
\hline Good deed & Romance/Comedy & Female \\
\hline Diary of a mad black women & $\begin{array}{l}\text { Comedy-drama/ } \\
\text { Romance }\end{array}$ & Female \\
\hline War room & Drama & Female \\
\hline Preacher's wife & Drama/Fantasy & Female \\
\hline Why did I get married? & Drama/Fantasy & Female \\
\hline Addicted & Drama/Thriller & Female \\
\hline Faith like potatoes & Drama/Biography & Male \\
\hline Noem my Skollie & Drama/Crime & Male \\
\hline Passion of Christ & Drama & Male \\
\hline
\end{tabular}




\section{Findings}

The findings will be summarised as themes that indicate which factors play a role in how participants construct meaning, as well as how and to what extent the content and experience gained from watching film, impacts on how they live their life. Identified themes are informed by direct quotes from the interviews.

\section{Socialised into Watching Films by Parents}

Shiraad

Descriptions of the Value of Film

Fatima

My mommy and I have a very good, we have a close relationship. Especially during the night-ime, she will sit and talk with me because my father was always a bit too busy so he is tired. So, I will sit and talk with her, but then afterwards we will watch movies so from small I watch horror movies. My mommy likes horror movies so I never really felt scared because she was always there but as I grew into it. For me it is like watching a comedy now. I like romance only because of my mother. I was forced to watch it when I was younger. She used to watch romance.

Fatima

Christine

Christine I love movies. I watch whenever I can. Basically to me it encourages me. Like I said, if I watch a movie, it is something I can always learn from it

An eye opener, a guideline, also a lifestyle because it shows you where you could have been today.

War room I watch over and over again because it builds my faith. The reason is there are times in life where you doubt yourself. There was a time when I was down and out and war room gave me that help to take it step by step. I did not believe in prayer but now I do it constantly because I know prayer has power. I did not believe in prayer but that movie open the light for me and say that is where you should be at.

Christine Because it is an everyday life thing so not everybody would follow the 90 day rule. At the start it was that guys don't have respect for women - but sometimes we are too vulnerable. So I learned If man don't want to walk with me it is fine why should I force myself into something.

Fatima
I like comedy- it is excited it brings out the happiness in you even when you dull. You can sit there and put the comedy on and just laugh and feel better. 


\section{Mood and Mind-Set Plays a Role in how a Film is Received}

Shiraad ... it basically depends on my mood.

Shiraad Yes, but it depends on what mind-set you are watching.

Christine I watch a movie to learn from it so your mind set counts.

\section{Religious Views and Convictions Play a Role in Interpreting Film}

\begin{tabular}{|c|c|}
\hline Shiraad & $\begin{array}{l}\text { It basically tells you that you cannot just trespass everywhere you go. } \\
\text { You cannot just go and dance on graves and think everything will be fine, } \\
\text { because, according to my upbringing and my religion, even if you are in the } \\
\text { grave, there is life after death, so you disrespect that persons. You cannot go } \\
\text { and do that. Every action has consequences. }\end{array}$ \\
\hline Fatima & $\begin{array}{l}\text { Like I am more a religious person, so I am not going to take anything from } \\
\text { a movie unless it is really something I can learn from. I like movies where } \\
\text { I can learn from. }\end{array}$ \\
\hline Fatima & $\begin{array}{l}\text { Like in our religion, no matter if the person has sand on his teeth and the } \\
\text { person greets you, you must greet back. It is a must for you to make that } \\
\text { person feel welcome. }\end{array}$ \\
\hline Fatima & $\begin{array}{l}\text { In movies they are drinking. Us as Muslims we cannot, so to have a head } \\
\text { on your body, you think for yourself. What they are doing is wrong, so } \\
\text { religiously I can't, so I am not going to. }\end{array}$ \\
\hline Shiraad & $\begin{array}{l}\text { I am still young and I like watching movies, but religiously TV is forbidden } \\
\text { (garam) because of what is being played on the TV, because it can also } \\
\text { take away time. Like, for instance, we have times a day we have prayers. } \\
\text { Now if you are watching a movie and it is interesting like 'Fast and furious' } \\
\text { or 'Blade', even if I hear the call for prayer time, I will watch. What I am } \\
\text { saying, it can take away time and take you totally away from what you } \\
\text { have to do, that is the reason why it is (garam) to watch TV unless you can } \\
\text { control yourself. But growing up is difficult, especially when you are young, } \\
\text { you just want to do your own thing. }\end{array}$ \\
\hline
\end{tabular}


Personal Life Story seems to be the Most Important Lens through which Meaning is Constructed

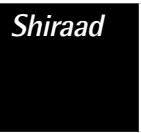

Shiraad

Fatima

Fatima

Estelle
Harry Potter, for instance, his courage and his motivation, it tries to tell you that even if you are the weakest, you can defeat the strongest if you a good spirit, good heart and you put your mind to it.

If I watch a movie like 'Fast and furious', basically their mission is always complicated. So I take it upon myself; maybe my matric is now my mission, now it gets complicated, it gets hard, it gets a bit tough at times, but that is what every mission has. It is what I make of it that determines at the end of the day my result, so I just keep going just like in the 'Fast and the furious'. Ride or die.

Oh, okay, I love 'Titanic', I must admit it up till today I have it recorded and I watch it. It shows you must take risk and you must be cautious because you do not know the person what they are about, but when that love, that passion is there, when you feel connection is there. This is what happened between my husband and I, we did not know each other for long, yet we are connected, we felt that.

And that make me more passionate towards my husband, because I am a very independent woman, because that is the way my mother raised her daughters to be independent, as she is a single mother. It was tough for me to accept the fact that my husband is working for me and I am not working for myself. Religiously it was his duty to work for me, and I had to accept that fact and I became passionate about it. I decided I am going to appreciate you, thank, and kiss him on his forehead every night he comes home, and say thank you for taking that burden off my shoulders to see to myself. You need to appreciate what you have in life, especially towards your partner. Appreciation, appreciation, appreciation, it is a big deal.

That you should not hold yourself back because you don't have what others have. Like, for example, I am short and cannot do what normal people do. My length is not normal, but I should not blame myself for it, because God will not give you a cross you cannot bear.

Christine The reason is there are times in life where you doubt yourself. There was a time when I was down and out and 'War room' gave me that help to take it step by step. I did not believe in prayer, but now I do it constantly because I know prayer has power. 
If $\mathrm{I}$, for instance, watch a film that says something of the circumstances that I grew up in. Divorce. It helped me to overcome the fact that my parents are divorced. It also helped me to be a better person. I married recently and I must act as a husband for my wife and live out the values of a good father

\section{Context Plays a Role in the Interpretation of Film}

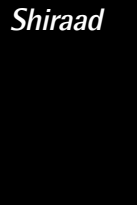

Shiraad

\section{Shiraad}

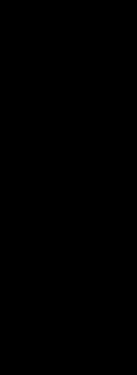

Fatima

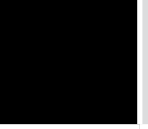

Estelle
Like for 'Blade', I grew up loving that movie. It is this guy, Wesley Snipes, because of his style in that movie, a different character. It is vampire movie, but to see an African American as vampire that has his own style. It brings a different style to the whole story of being a vampire because if you watch vampire movies you only see this white guy who is dressed nicely.

Yes, it is better that way because each race has a different style, but it just impresses me to see the different styles.

It can be destructive I think, because I watched a couple movies where they do robberies and look at the gangsters, they are very creative nowadays because they watch these movies as well and get ideas from these movies. I was working as assistant pastry chef after I returned from my studies and they actually robbed these money vans every end of the month. It was very much organised and I am thinking to myself it is very much what they do in the movies. They are learning, I am mean the hijacking of the cars, it is all coming from the movies and gives people now a wider understanding of why don't we do this, we can do this and it is possible to get away with it if we do it this way. It gives them ideas.

'Four corners' for instance - it shows you how society is outside and how you must take extra steps in protecting yourself in your own environment, because gangsterism can come knocking on your door anytime. You don't ask for it, you fall into that trap.

The day the Lord make it possible to play in a movie, I would like to take the role of the woman that is abused. Because I see around me how men abuse women and not all are strong enough to stand up when they fall in life.

\section{Discussion}

The favourite genre identified from the list of films was drama/fantasy. It was interesting to note that although participants indicated that they are active religious individuals, they do not favour explicit religious films. Most movies listed are not explicitly religious in nature except three, namely Faith like potatoes, War room 
and Passion of the Christ, which focus on religious themes, namely faith and prayer. Clark (2003:22) found in a study on the role of media in the construction of religious identity, that teenagers prefer films that are not explicitly religious. Hjarvard (2008:20-21) made a similar finding in research among youth on the role of media in spiritual formation. Media forms like watching television, going to the cinema and internet discussions and websites were identified as playing a bigger role in spiritual formation than explicitly religious activities like going to church and reading the Bible. Responses to a question on which specific media forms provided the most spiritual guidance, film and television were at the top of the list. This may allude to the power of film to captivate audiences and reflect how viewers, especially those with a religious background like in this study, read religion into film even though it is not explicitly present in the storyline. Religious background therefore plays a significant role in how they engage with the content of film and construct meaning for their lives.

Explicit references were made to how religion gives direction to viewers in terms of which messages to accept or behaviour to adopt and which not. Both Shiraad and Fatima related how their religious convictions prohibit them from adopting certain behaviour often portrayed in movies like drinking, and motivated following other behaviour, like treating all people the same and making them feel welcome. It is therefore clear that their religious views and knowledge assist them in deciding which behaviour should be followed or not. Christine also told how War room brought about what can be phrased as conversion in her life. The film convinced her of the power of prayer and inspired her to make prayer a part of her life. Prayer is a religious practice that is central in, for instance, Christianity and Islam, the two most prominent religions in South Africa. Christine testified how watching this film changed her life and continues to do so because she watches it repeatedly, whenever she has time.

Rishaad mentioned more than once that he loves watching movies. At the end of the interview he, however, stressed the fact that watching TV is forbidden by his religion, because it is time consuming and clashes with religious responsibilities like prayer. This finding alludes to the most common response of traditional religion to media. The relationship between theology and technology is characterised by at least three views of the media, namely media as oppressor, media as liberator, and media as instrument (Cloete, 2015:2). At least two of these views of media are opposites. The view of media as liberator postulates that media could be used to liberate the world by religion, whilst the view of media as oppressor paints media as an enemy of religion. Although these views are not necessarily wrong, both demonstrate a very limited understanding of the complexity of media on the one hand, and the power 
of an engaged user on the other hand. It is clear in Rishaad's response that his religion's stance against watching TV and his need to do so, causes tension in his life. His response further alludes to the fact that there seems to be a disconnection between this religious stance and his everyday reality and needs as a young person to participate in popular culture like watching film. Therefore, a more nuanced view of the media by theology and religion is needed, where the media is viewed as ambiguous, and not just bad or good. Campbell and Garner (2017:34) makes a plea for a bifocal view of the media, which implies finding a middle way between the two extremes of liberator and oppressor. Such an approach acknowledges that media is not value neutral, but is not inherently good or inherently evil either. Such a view is simple, but complex at the same time. Rishaad has to negotiate between the official stance of his religion and his needs as a young person. At the same time, it confirms that the values imbued in the family do have a significant impact on young people. He was introduced to, and to a certain extent socialised, by his mother, in the activity of watching film. This and his needs as young person may play a role in his choice to live with this tension caused by the fact that watching film is forbidden and his choice to still do so.

Participants explained that what they learn from films assists them to cope with difficulties in their lives. Fatima articulated the value of comedy as making you laugh and feel better, even when you are feeling dull. Rishaad told how watching films strengthened the relationship between him and his mother while helping them to cope with the fact that his father was tired and did not have energy to spend time with them. Moreover, film assists them in their personal lives, with intimate relationships, as both Estelle and Fatima explained. Fatima, the married woman, testified about how she is more passionate and appreciative towards her husband as a result of what she learned from watching Titanic and The Notebook. Christine was clearer on what she expects from a relationship because of what she learned from the 90-day rule in Why did I get married? Estelle was able to accept that her length is not normal, but that she does not have to feel guilty about that. Instead, she can live a fulfilled life despite being so short. Lionel, the married male, relates to divorce in film because that was part of his childhood. He said that watching films about divorce helped him to overcome that difficult experience and inspires him to be a good husband to his wife and a better person in general. Shiraad finds film in general inspiring and motivational and compared his matric year to the film Fast and furious, viewing matric as a mission that he needs to complete despite challenges that he may experience. The stories in films therefore inspire and motivate young people in their relationships and other challenges they may experience. 
Destructive messages in film identified by respondents are gangsterism, drug abuse and gender-based violence. These are of the most destructive forces in their immediate environments, which stood out for them in films, because the films are reflections of their own communities. Hence, the concern of especially Shiraad, that such movies could give gangsters ideas on how to be more effective criminals. Gender-based violence, gangsterism (which breeds violence), and drug trafficking are some of the most serious socio-economic challenges in South Africa. The reference to race by Shiraad with regard to the film Blade, is also of interest, especially within the South African context, where race continues to play a significant role in religious, economic and political spheres. It seems that he was surprised and touched by the fact that a black person played the role of a vampire, normally portrayed by white people. The style and uniqueness of the character as a black person, brings something special to the film and makes him appreciate it more.

\section{Conclusion}

Respondents indicated that they like watching film and do so whenever they have time, implying that it is an everyday practice, which forms a meaningful part of their lives. The reason for watching may be for recreational purposes, but it was also clear that education takes place and that the value of this everyday activity shapes their worldview, as well as how they live their lives.

Personal life stories seem to be the most significant lens through which respondents receive stories and through which meaning is constructed. The discussion above demonstrates that film does have meaning for viewers and does fulfil some religious function. I would argue that the religious value or function of film in a viewer's life is embedded in how the film speaks to his or her own personal life story and circumstances. It seems that film shows them how to live their lives. What makes this more powerful, is the fact that they are not forced or pressurised to do anything, but are touched and inspired by the package film offers, namely the story, music and images. The viewer, however, has the choice and power to interpret the message or the meaning of the film for him- or herself. The meaning of film is indeed a negotiation between the viewer, text and context. Film, therefore, does not have a prescribed and universal understanding or message as is often the case in formal institutional religious teachings and messages. Institutional religion often strives to protect especially young people from the world, and the media is often viewed as one of the primary mediums that expose youth to the bad things in life. The negative influence of media is not ignored, but this study found that film definitely also has a positive influence, especially in the lives of young people. The phrase at the beginning of the chapter summarises well what was found in this study, namely 
that film is informative and educational, and can be a religious resource with the ability to provide moral guidance on how to live your life and inspire life changing practices like leading a prayerful life.

\section{Bibliography}

Axelson, T. 2017. Movies and the enchanted mind: emotional comprehension and spiritual meaning-making among young adults in contemporary Sweden. Young, 25(1):8-25. https://doi.org/10.1177/1 103308816668920

Campbell, H.A. \& Garner, S. 2017. Networked theology: Negotiating faith in a digital culture. Grand Rapids: Baker Academic.

Clark, L.S. 2003. The 'funky' side of religion: An ethnographic study of adolescent religious identity and media. In: J. Mitchell \& M.J. Marriage (eds.), Mediating religion: Conversations in media, religion and culture. London: T\&T Clark. pp.21-32.

Cloete, A. 2015. Living in a digital age: The need for theological reflection. HTS Theological studies, 71(2): 1-7. https://doi. org/10.4102/hts.v71ii2.2073

Cloete, A. 2017. Film as medium for meaning-making: A Practical theological reflection. HTS Theological studies, 73(4): 1-6. https://doi.org/10.4102/hts.v73i4.4753

Ganzevoort, R.R. 2011. Framing the gods. The Public significance of religion from a cultural point of view. In: L.J. Francis \& H.G. Ziebertz, The public significance of religion. Leiden: Brill. pp.95-120. https://doi. org/10. 1 163/ej.9789004207066.i-495.45
Grant, M.R. 2003. Christ and the media: Considerations on the negation of meaning in religious television. In: J. Mitchell \& M.J. Marriage (eds.), Mediating religion: Conversations in media, religion and culture. London: T\&T Clark. pp. 121-130.

Hjarvard, S. 2008. The mediatization of religion: A theory of media as agents of religious change. Northern Lights, 6:9-26. https://doi.org/10.1386/nl.6.1.9_1

Mahan, J.H. 2014. Media, Religion and Culture. London: Routledge. https://doi. org/10.4324/9781315777061

Marsh, C. 2009. Audience Reception. In: J. Lyden (ed.), The Routledge Companion to Religion and Film. New York: Routledge. pp. 255-274.

Miller-McLemore, B.J. 2012. Christian theology in practice: Discovering a discipline. Grand Rapids: William B Eerdmans Publishing Company.

Staiger, J. 2005. Media Reception Studies. New York: New York University Press. 
Film is a universal and esteemed medium from which messages are often sent which are capable of influencing and conditioning the choices of the public and especially young people.

Saint John Paul II, 29th Communications Day

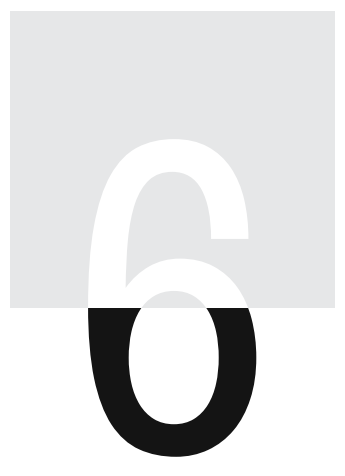

\section{FILM AS \\ DISCUSSION \\ PlatForm \\ IN YOUTH \\ MINISTRY}

Nathan Chiroma interviews. The key findings revealed that film can facilitate discussion in youth ministry in the following ways: spontaneous modelling, mentoring, raising awareness and discussion, informing and deepening the knowledge of young people, encouraging thematic discussion, providing new insights and perspectives and by creating change in behaviour.

Films have the power to influence the thinking of young people. Historically, films have changed society and social trends and introduced new fashions in society. Films may be described as trendsetters, because it has a direct bearing on young people's social life. Films can go a long way towards arousing 
meaningful discussion and also in utilising the energies of young people for social reconstruction and nation-building. Young people live in a world inundated with all forms of films, and the reality is that not all of those films carry positive messages. Extraordinary films containing teachable moments with direct bearing to God's Word for young people are few and far between. However, studies by Kohl (2012), Brandon (2013) and Bosco (2007) have shown that film could be an invaluable platform for discussion when working with young people. Using film as discussion platform in youth ministry provides valuable opportunities to engage young people who might not traditionally be involved in our youth ministry. Film has the power to enthuse young people and it allows them to adopt new identities, hear new voices and to see the world from many different points of view. According to Jensen (2015:89), film brings young people news of other cultures and other values. The perceptible collective ability of film to excite and engross young people, together with the fact that it challenges them to think, encourages empathy and compassion and provoke laughter and tears make film an ideal catalyst for discussion in youth ministry.

The role and impact of film in the lives of young people is undeniable, and therefore the notion that a film equals entertainment only could not be further from the truth. Ever since its formation, film has demonstrated to be far more than an unadorned tool for entertainment only. Consequently ministry to young people using film as a discussion platform is vibrant and exciting work and also significant to the life of the church. There are many ways to harness the power of film to heal, grow and change young people for the better. For example, in Cameroon, during the Bamenda Human Rights Film and Arts Festival 2013, various panel discussions were held among young people on topics related to violence against women, human trafficking, discrimination towards girls and domestic violence - topics that were featured in many of the films shown at the festival. The organisers were pleasantly surprised by the quality and meaningfulness of the contributions that young people brought to the table during the panel discussions (Hunter, 2013:5).

Film exerts a significant influence on the minds of young people and, if harnessed correctly, could also have profound educational value. Being an inextricably part of the multi-dimensional framework of youth culture, film can achieve splendid results as a discussion platform in youth ministry. Young people have conversations with each other on the latest films. Because film has such a powerful sway on today's young people, it is fundamentally important that those who work with young people embrace the power of film as a discussion platform in youth ministry. Borgman (1997:138) aptly notes that "our goal as youth ministers is not to show young 
people how much we know. They will quickly humble us if we try to impress them with any such knowledge. Rather, we want to study with them and learn their ideas about film and music. We are interested in their empowerment to discern and protect themselves from the manipulation of electronic communication."

This chapter contemplates the place of film as a discussion platform in youth ministry. The first section of the chapter provides working definitions of film, young people and youth ministry. Subsequently, the role and impact of film in society and youth ministry are considered, after which the methodology is explained. The key findings are presented in a thematic manner, paving the way for a discussion of the implications of the study in youth ministry. The chapter concludes with some suggestions and a brief overview.

\section{Defining Core Concepts}

To ensure clarity and to delimit the material, this section offers some foundational definitions of concepts used in this chapter.

Fillm: The Collins Online Dictionary defines film as "consisting of moving pictures that have been recorded so that they can be shown at the cinema or on television. A film tells a story, or shows a real situation" (Collins Online Dictionary, n.d.). For the purposes of this chapter, film is defined as any moving picture that can be accessed via cinemas, television, YouTube and phones or other electronic devices. 'Film' and 'movie' may be used interchangeably.

Young people: The definition of young people varies from one context to the other. For the purposes of this chapter, young people are defined as those within the age bracket of 14-35 years, since various countries and various youth ministries differ in their definition of young people.

Youlth ministry: Simply put, youth ministry is the Church's efforts to assist young people to grow personally and spiritually. Hence, the rationale of youth ministry should be to prepare young people for effective ministry within the context of a local church or a parachurch organisation. Bomas (2016:76) adds that training young people to champion the cause of Christ and to apply Christianity to every area of life is what 'youth ministry' is about. Youth ministry in the context of this chapter refers to every endeavour by the Christian community to reach out to young people with the love of God as disclosed to us in Jesus Christ through the power of the Holy Spirit. 


\section{The Role and Impact of Film in Society}

The role and impact of film in society cannot be overemphasised. Film tells stories about our society and who we are, as well as record of what makes us human and what concerns us in the everyday. Even though the influence of new media technologies may seem to have changed the way we now watch films in that film are consumed not only in the cinema anymore, but also at home and online, films are still very much part of the media landscape. Film has played a major role in changing our society. Kubai (2002:14) notes that patriotic movies remind us to love our various countries. Comedy films have treated many a patient by means of laugh therapy. Adventure films have given many a sense of adventure and challenged them to explore new possibilities. In addition, film has impacted society in the following ways:

Film offers us a language to speak to each other across national, class, economic and racial lines, the bonding power of film produces unified understanding that normally cuts across boundaries. During the Second World War, film is said to have been a uniting factor between warring factions. Film is a reflection of society, both present and past. According to Gray (2010:68) film and its innovations sometimes has to catch up with society, but often it also leads society. Films are stories; films represent the people who come out with ideas about something they want to say, something they want to tell someone. Film is a form of communication and that communication tells stories coming from societies, not only about where a society is presently and what it is doing now, but also about where that society has been.

Film can be used for promoting national integration in that it usually embodies and conveys the values and beliefs of the culture within which and for which it was made. Additionally, film has the ability to help us to understand other cultures and people. Popular art forms such as film are of special importance because they speak to the most central of those values and beliefs. Furthermore, film has an extraordinary capacity to expand our reality, to deepen our moral sensibility, and to shape our self-understanding by moving us closer to cultures, problems and realities that are distant from those we know well. Gauntlett and Hill (1999:50) assert that film works so well because it conveys us into its world with barely any effort on our part. In a more reflective sense, film tells us something about ourselves and gives meaning to our lives. Even while apparently mindlessly absorbed in the film, we are delicately and instinctively washed with a coating of cultural values, unrealistic aspirations and an understanding of good and evil. 
Correspondingly, film engages our vision, ideas and feelings. According to Staiger (1992:4), capitalising on the power of film to capture the environment and reality, many producers create structured experiences that engage us profoundly and sometimes change our awareness or feelings about our lives or the things around us. As an art form, film offers experiences that carry particular nuances and meanings that can be provocative, puzzling or euphoric. The emotional function of film also helps to teach the audience to adjust their emotional responses and reactions to certain aspects of their social lives. The overall form and style of presentation of the stories in the film work harmoniously and guide us into a new experience.

Biographical films of great philosophers and thinkers shed light on their way of living, which provide us with knowledge that we may not have obtained otherwise. This knowledge can shape the way we engage with the content of their work, and, at the same time, help us to develop new ideas that will enhance our engagement with their work. Films in the form of autobiographies help us to appreciate the heroes and heroines in our history and could encourage loyalty and nationalist sentiments. Richards (2003:341) argues that good films always have some theme and moral lessons. For example, we may have heroes, heroines and villains, with the villain usually being conquered in some way by the end of the film. Films can illustrate how bad actions lead to bad results.

Films can create debate, conversation and atmosphere. Lionel (2017:4) observes that film has provided a platform for young people to debate racism and extra-judicial killings by police in the wake of the 'black lives matter' movement in the USA. Film has also been a great tool in creating and sustaining conversations about pertinent issues in society. Anderson (1978:155) argues that in the early days of film in Europe, it was used to create conversation in public places, schools and even in churches. The widespread use of film as a source of conversation sparked meaningful exchanges in various communities, which resulted in value change and policy changes. Film has also proven to be a means of providing atmosphere for dialogue and reconciliation - for example, film was used as a means to bring about reconciliation and forgiveness after the Rwandan genocide.

Given the above, it can be argued that film still does have an impact in our society today. However, what remains pertinent is the ways and modes in which we can engage film to enhance meaningful discussion in our society and, more specifically, in youth ministry. 


\section{Methodology}

Qualitative methods were used for data collection for this study. Focus-group discussions were employed to collect specific data, and the discussions were guided by Osmer's (2008) pragmatic task phase of "how might we respond?" Osmer (2008:28) describes the four tasks of practical theological research as follows:

1. The Descriptive-Empirical Task ("What is going on?"): Priestly Listening - This is established in a theology of being there, attending to others in their particularity within the presence of God.

2. The Interpretive Task ("Why is this going on?"): Sagely Wisdom - This is grounded in a spirituality of sagely wisdom: guiding others in how to live within God's royal rule.

3. The Normative Task ("What ought to be going on?"): Prophetic Discernment-This is built in a spirituality of discernment, helping others hear and heed God's Word in the particular circumstances of their lives and world.

4. The Pragmatic Task ("How might we respond?"): Servant Leadership - This is based in a spirituality of servant leadership, taking risks on behalf of the congregation to help it better embody its mission as a sign and witness of God's self-giving love.

The research described in this chapter embraced Osmer's (2008) pragmatic tasks to conduct focus-group interviews in order to investigate how film can be used as a discussion platform in youth ministry. According to Schurink, Schurink and Poggenpoel (in De Vos, 1998:324), focus-group interviews are useful for:

- conducting research at a relatively modest cost and in a relatively brief period of time;

- allowing the researcher to probe and create the flexibility that is so important for exploring unanticipated issues;

- developing themes, topics and schedules for subsequent interviews and/or questionnaires;

- providing speedy results;

- shedding light on little-known phenomena and social processes;

- developing concepts or theoretical explanations of what was observed (McMillan \& Schumacher, 2001:14); and

- purposefully determine the perceptions, feelings and thoughts of participants. People are the product of their environment and are influenced by other people.

The participants in this research were youth pastors and youths ranging between the ages of 14 and 35 years. Gender was not considered in this study. A total of eight youth pastors and 14 young people in Nairobi participated in the study. All of them were from different churches and parachurch organisations. Although this was a convenience sample, with both pastors and young people selected on the basis of 
their accessibility and willingness, all the participants were from the Nairobi district and represented evangelical and Pentecostal churches. Nairobi was chosen as the centre for the study because of its cosmopolitan nature and the role the city plays in influencing what happens in youth ministry in other parts of Africa.

Two focus-group sessions were conducted. The first focus group comprised a total of 8 youth pastors from the eight different churches that participated in the focusgroup interviews. The second two focus-group interviews comprised young people (ten men and four women), focusing on the central research question. Homogeneity of the participants was considered in order to obtain their knowledge of film as a discussion platform in youth ministry. Permission was granted by both parents and youth pastors for those under the age of 18 , and considerations regarding the ethics of the study were also explained to the participants, highlighting to them matters of confidentiality and permission to discontinue their participation whenever they felt like doing so.

The central question that guided the study was: What is the role of film in the facilitation of discussion in youth ministry? Other questions that guided the focus-group discussions were:

- How often do you use film as a discussion tool in youth ministry?

- What is the impact, (if any) of using film as a discussion platform in youth ministry?

- Mention specific areas that you think film has contributed to the formation of young people.

- What are some of the challenges of using film as a discussion platform in youth ministry?

- Which films have produced a major impact in your life as a young person?

- In your experience as a youth pastor, which films have produced the best discussion platforms?

- Where do you get the films that you use with your young people?

- What are the criteria for selecting the films you use for discussion?

The interviews were conducted over a period of two months, interviews were recorded with the permission of the participants, and the records were securely kept in the researcher's office on the premises of Pan Africa Christian University.

\section{Key Findings}

Thematic analysis was used to interpret and discuss the data of the findings in this chapter. Thematic analysis is a type of qualitative analysis that is used to analyse classifications and present themes (patterns) that relate to the data. It 
illustrates the data in great detail and deals with diverse subjects via interpretations (Boyatzis, 1998:78). Thematic analysis was chosen because this method presents an opportunity to understand the potential of any issue more widely (Marks \& Yardley, 2004:9). Six themes emerged from participant's narratives on how film can be used as discussion platform in youth ministry, which will be discussed below.

\section{Film can Promote Spontaneous Modelling through Discussion in Youth Ministry}

The participants, in particular the youth pastors, expressed that using film as a discussion platform in youth ministry provided an opportunity for spontaneous modelling. The participants were of the opinion that film as a platform for discussion could offer an opportunity for young people to model after positive characters. This is in line with Bandura's (1973:5) social cognitive theory of learning where he argues that young people learn behaviour change more efficiently through spontaneous modelling. New concepts and narratives provided in films give young people the opportunity through discussion to form new ways of responding to social issues in a constructive manner. In the words of the contributors:

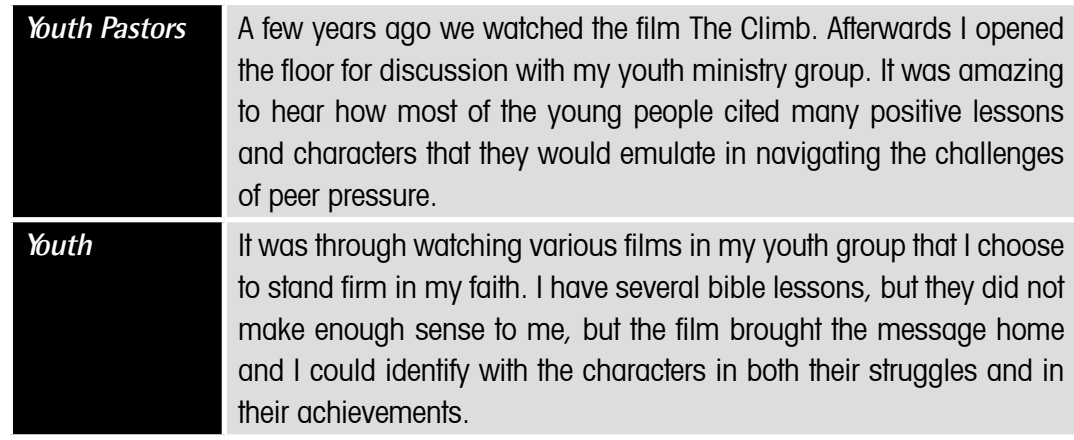

The respondents were asked to identify one film character that has contributed to spontaneous modelling in their lives. Among the top names mentioned were Denzel Washington, Lupita Oyango, Richard Mofe Damijo, Edi Gatheji and Oliver Litondo.

\section{Film can Promote Mentoring through Discussion in Youth Ministry}

Particularly the youth pastors mentioned that using film as a discussion platform in youth ministry had the potential of providing young people with distant mentors. They added that teenage years were characterised by hero worship, and that many 
young people would emulate the life styles of the movie stars that they perceived as successful. However, with proper discussion, young people could be guided to choose the right distant mentors - role-models that will add value to their lives.

One of the young people echoed exactly this sentiment:

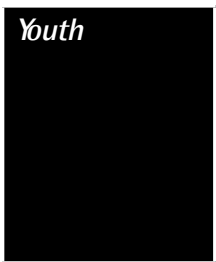

I decided to choose the late Nelson Mandela as I my distant mentor, even though I have never met him. Through watching films about him and his life story, I thought I would want to emulate his lifestyle and would want to be like him throughout my life. His story about courage and resilience taught me how not to give up in school even when I was having difficult times with many of my teachers.

Another youth said that he has identified significant distant mentors in his life through film:

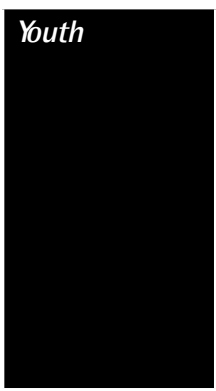

My youth pastor introduced me to positive distant mentors through film. We would go to the movie theatres and after the movie we would hang out with him over lunch to discuss the impact and the challenges in the movie. That introduced me to many strong Christian movie actors that l've never heard of in my life, and that prompted me to do a study about them and in the end their lives and their values contributed to shaping my live and my values today. I choose to call them my mentors even though we have never met, but they impacted my life.

From the aforementioned, it is evident that film, if used as a platform for discussion in youth ministry, has the capacity and the ability of introducing young people to distant mentors.

\section{Using Film as a Discussion Platform in Youth Ministry can Inform and Deepen the Knowledge of Young People}

Most of the participants have identified film as having the ability to deepen the knowledge of young people in different areas. The youth pastors alluded to the fact that films like Courageous, Not without my Daughter, and The Jesus Film have contributed immensely in deepening the spiritual knowledge and character of the young people they work with. They said that such films sparked meaningful conversations around spirituality and character development. 
With regard to deepening knowledge and character, the youth respondents stated:

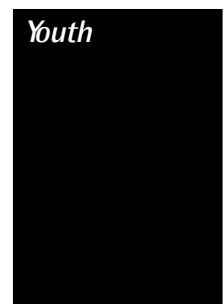

Youth
My character was really changed after attending a couple of youth meetings and watching and discussing The Jesus Film in my language. It truly brought about a turnaround especially in my relationships with my parents, my siblings and even my school mates. The desire to be like Jesus was ignited in my life like never before. I grew up in a Christian family and we got lessons about Jesus in our daily family devotions, but it never really hit me like the film did. The reality of HIV/AIDS became so close to me after we watched a film about its spread in Uganda a couple of years ago. I have read books and have heard many talks about the pandemic, but our discussion after watching the film at our youth group deepened my knowledge about what HIV/AIDS is all about and not only how to avoid it, but also how to support those affected by the pandemic.

Robins (2004:541) points out that there is a connection between film and the awakening of young people's awareness of different matters. Film has a way of teaching them the lessons that we as youth workers struggle to teach. Film brings to life situations that we are not able to describe or even imagine when it comes to the deepening of knowledge of certain issues in youth ministry.

\section{Film as a Discussion Platform can Encourage Thematic Discussions in Youth Ministry}

According to Nicholas (2013:30), film provides an ideal opportunity for thematic discussion in youth ministry. There are strong connection points that we could often miss in an ordinary discussion, since our function usually is to take the lead in these discussions. Using film as the basis of the discussion we are engrossed in the conversation together with our young people, and that provides an opportunity for picking out themes for further discussion together and even for programming our youth ministry.

According to the youth pastors:

Youth Pastors
I was afraid to use film in my youth group because of the elders' and church leaders' perception of film, however after using one at the youth camp where it generated thematic discussion points for the whole year, it made my work easy. Even more so, it helped organise the teaching and learning process in our youth group. 

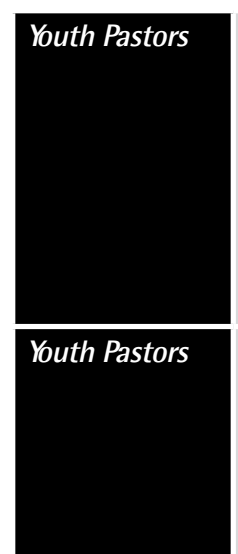

From the film Never Walk Alone, I was able to generate four themes for my life which I later shared with other youth members in my church. The themes enabled me to dig deeper in the Bible to be able to find verses that will encourage my Christian journey. The four themes that stood out for me from the film, were: we are here for each other; the Christian journey is all about compliment and not competition; we ought to bear each other's burden; and there is power in unity.

After showing the film The book of John, I couldn't believe the notes that my youth group generated from the discussion. We pulled out a series of points and asked each one of us to develop it for a personal and group Bible study. I was amazed at the themes that came out and the themes that stood out for the young people.

\section{Film as a Discussion Platform can Provide Insights and Perspectives in Youth Ministry}

According to the respondents, film as a discussion platform in youth ministry provided opportunity for insights and perspectives in youth ministry, especially in dealing with sensitive issues such as taboos, sexuality and culture. Koc (2016:108) affirms that when dealing with sensitive issues, film played a vital role in creating a safe space for discussion among young people and their teachers in Turkey. Many who were afraid to talk about certain issues used film to spark a conversation about it. This gave them courage to make a meaningful contribution about the subject, but they also admitted gaining new insights on the subject thanks to the discussions that were triggered.

According to the respondents:

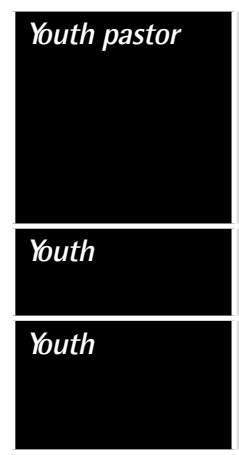

I have used film to initiate dialogue among young people who initially misunderstood either the subject or the person. Film created a huge space for discussing the LGBT issue in our youth group. At the end many of us were educated with a different perspective - different from the ones we had about the whole issue before.

Film gave me insight and new perspective about the culture and the people of Israel after watching The Jesus Film.

After watching a South African film about circumcision, I was totally blown away by the reality of the story as compared to the myths we have been told growing up about circumcision in South Africa. 


\section{Youth pastor}

Because of pressure by church leaders and fear of authorities, it was sometimes extremely challenging for me as a youth pastor to discuss certain topics with my young people. However, after discovering the power of film to negotiate discussion, I was empowered to discuss every topic with my young people using film as the basis of the discussion. We had an extensive discussion for three week about sex and sexuality after watching the film The Climb.

\section{Using Film as a Discussion Platform can Create Behaviour Change in Young People}

The respondents said that:

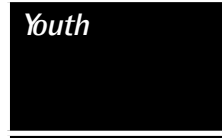

Youth

Youth pastor
After watching and discussing the film Risen in our small youth ministry group, I became completely aware of my arrogance and pride and decided to change for the better.

I used to struggle with a lot of anger, but the film Men of Valour taught me patience and I asked my friends to hold me accountable so that I can overcome that.

The film Courageous taught me how to be a good husband today, the materials that we used to discuss the film are still on my shelf and I keep referring to them very often

From the above it is clear that using film as discussion plafform in youth ministry has an impact on young people in various ways. Both the literature and this empirical study have further confirmed that film is a helpful tool in creating meaningful discussion platforms in youth ministry.

\section{Implications for Youth Ministry}

The benefits of using film as discussion plafform in youth ministry are manifold. The following implications are emphasised for the benefit of parents and youth workers:

1. Young people are in search of exhilaration, adventures and laughter, and using film as a discussion platform in youth ministry could help provide that. For example, Edwards (2007:6) cites that in the film, Shadowlands, C.S. Lewis is told that "one reads to know they're not alone". The same could be said of young people and film today; they watch films to know that they are not alone. Other peers are watching the same films too, and the stories that develop motivate, relieve and encourage young people in unique ways. Hence youth workers should embrace the use of film as a discussion plafform in youth ministry. 
2. Youth workers and parents should listen and watch to see what these films are saying. Often, young people identify with themes and stories, while they have no way of articulating their personal needs, dreams and hopes. Parents and youth workers should take care to pay attention and to gently enter a sphere often overlooked or judged by adults. In doing this they would win admiration and trust by simply caring enough to see what the young people themselves see and by providing them with an opportunity to ask questions and to even verbalise their own doubts.

3. There is a definite need for youth workers to help guide young people in this area. By using film as a discussion plafform, young people can open up and share secrets they otherwise would not have. Information gathered from such discussions could be used to create lesson curricula in youth ministry.

4. Film should also be used to pique young people's interest in order to facilitate meaningful conversations and discussions. The creative use of popular films and video clips on topics ranging from sex, lying, adultery and homosexuality to anything else could challenge young people about their own beliefs and morals and create avenues for rich discussion. Spirituality can be discussed in the same way. Young people can be encouraged to use the discussions to create their own talk shows about such issues as sexuality, morality and religion.

\section{Conclusion}

This chapter has probed film as discussion platform in youth ministry. The role and impact of film in society was highlighted by means of an overview of the applicable literature, and the empirical study demonstrated that using film as a discussion platform in youth ministry can indeed enrich interaction and engagement between youths and their pastors. The key findings of the study described in this chapter revealed that film can facilitate discussion in youth ministry in the following ways: spontaneous modelling, mentoring, informing and deepening the knowledge of young people, encouraging thematic discussion, providing new insights and perspectives and by creating change in behaviour.

Film can thus play a major role in youth ministry if used effectively as a discussion platform. Film and other media are part and parcel of the lives of young people, having been born in this era of technology and most of them cannot imagine a life without media. Many of them depend on films for research, staying in contact with old friends and staying up to date on what was happening in their own circle, nationally or internationally. Hence it makes ultimate sense for youth workers to harness film as a discussion tool in youth ministry. 


\section{Bibliography}

Anderson, D. 1978. Using films as tools for analysis in a psychology and law course. Teaching of Psychology, 19(3):155-158. https://doi.org/10.1207/ s15328023top1903_6

Bandura, A. 1973. Aggression: A social learning analysis. Englewood Cliffs, $\mathrm{NJ}$ : Prentice Hall.

Bomas, W. 2016. An Introduction to youth ministry in the local church. Nashville: Broadman.

Borgman, D. 1997. When kumbaya is not enough: A practical theology for youth ministry. Peabody: Hendrickson.

Bosco, A. 2007. Film and Religious reflections. San Francisco: Ignatius Press.

Boyatzis, E. 1998. Transforming qualitative information: thematic analysis and code development. Thousand Oaks: Sage.

Brandon, V. 2013. Media and Film: prospects and challenges for the $21^{\text {st }}$ century. Journal of Political Science Education, 9(1):52-72.

Collins Online Dictionary. N.d. Available at https://www.collinsdictionary.com/ [Accessed 1 July 2018].

Edwards, B. L. (ed.). 2007. CS Lewis: Life, works, and legacy, Vol.4. California: Greenwood Publishing Group.

Gauntlett, D. \& Hill, A. 1999. TV living. Television, Culture and Everyday Life. London: Bloomberg.

Gray, G. 2010. Cinema: A visual anthropology, Vol. 1. Oxford: Berg.

Hunter, M. 2013. Young People as Social actors. London: Routledge.

Jensen, Y. 2015. Word of mouth for movies: Its dynamics and impact on young people. Journal of marketing, 70(3):89.

Koc, M. 2016. Let's make a movie: Investigating pre-service teachers' reflections on using video-recorded role playing cases in Turkey. Teaching and Teacher Education, 27(1):95-108. https://doi.org/10.1016/j. tate.2010.07.006

Kohl, S. 2012. Shots in the mirror: films and society. Oxford: Oxford University Press.

Kubai, C. 2002. Working with young people: Opportunities for development. Nashville: Abingdon Press.

Lionel, A. 2017. Black, white or mixed race? Race and racism in the lives of young people. London: Routledge.

Marks, D. \& Yardley, L. 2004. Research methods for clinical and health psychology. Thousand Oaks: Sage. https://doi. org/10.4135/9781849209793

McMillan, M. \& Schumacher, R. 2001. Research in education: A conceptual introduction. 5th Edition. New York: Longman.

Nicholas, G. 2013. The role of film in traditional youth ministry. Downers Grove: Dorrance.

Osmer, R. 2008. Practical theology:

An introduction. Grand Rapids:

William B Eerdmans.

Richards, H. 2003. Memory reclamation of cinema going in Bridgend, South Wales, 1930-1960. Historical Journal of Film, Radio and Television, 23(4):341-355. https://doi. org/10.1080/0143968032000126636

Pope John Paul II. "Cinema: Communicator of Culture and of Values" From the Vatican. 6 January 1995. The Epiphany of the Lord.

Robins, L. 2004. Organized youth activities as contexts for positive development. Positive psychology in practice, 14(6):540-560.

Schurink, W.J.; Schurink, E.M. \& Poggenpoel, M. 1998. Focus group interviewing and audiovisual methodology in qualitative research. Research at grass roots, a primer in care professions. Pretoria: Van Schaik.

Staiger, M. 1992. Environmental impact of film and creative imagination. Buswuick: Dochess Press. 


\section{Introduction}

This chapter discusses film as popular culture by using the example of Superman, the 'Man of Steel', to examine how popular culture can influence adolescent masculinity constructions. Flowing from this discussion is the need for alternative theological perspectives on masculinity constructions. Practical theology and feminist theology are used to engage with the question of how these theological components can aid male adolescents who experience marginalisation due to the perpetuation of hegemonic masculinity. The conclusion considers spaces in need of alternative theological perspectives on masculinity.

\section{Towards a Definition of Popular Culture}

Popular culture as we know it originated with modern Western civilisation. It was preceded by folk culture, a form of culture that was more connected to everyday life and the lived experiences of the time. Leventman (2006:2) agrees that industrialisation made a marketable product out of most elements of modern life, including human experiences. Our experiences became mass-produced inventions rather than spontaneous events. This has been perpetuated in contemporary societies, where cultural experiences and practices have become commodities for trade. In the global village, culture has become so generalised that people do very little outside of popular culture. It permeates our experiences, reason, visualisations and even dreams (Leventman, 2006:2).

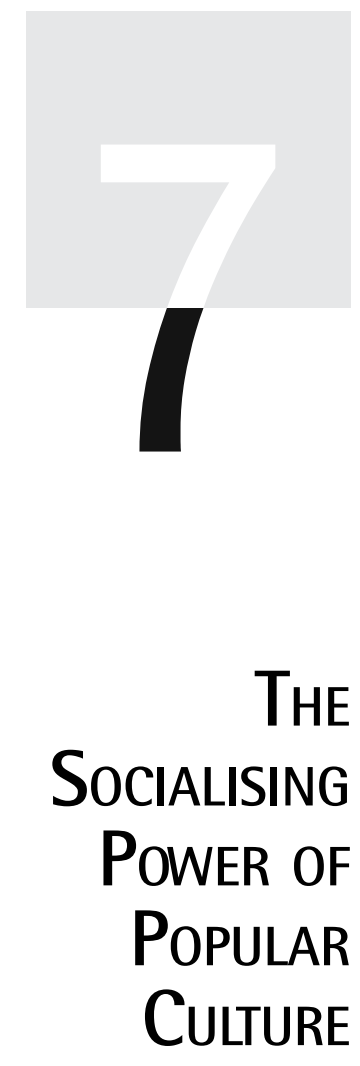

Superman and the Formation of Masculinity during Adolescence

Nathania Hendriks 
Hermes (2005:10) views popular culture as a ticket to cultural citizenship. It facilitates the process of bonding and community building. Popular culture serves as a collective psyche where events are imagined, re-imagined, interpreted, censured and celebrated in a way that creates an invented and imagined community. This leaves the individual with a sense of belonging, complete with duty, privilege and identity (Hermes, 2005:1). Since popular culture is an imagined space, it offers us the possibility to envision the hopes and dreams we have for humanity (Hermes, 2005:3). Popular culture invites the public domain into the private, especially by means of mass media. This blurs boundaries previous generations regarded as fixed - age, gender, ethnicity. This transposition makes popular culture in essence political, as it provides a platform for those who would otherwise not have a voice to engage with political and economic concerns (Hermes, 2005:11).

Popular culture counters the divisions created by high culture; it offers a sense of belonging and identity. It also provides the ordinary citizen with a social manuscript that is representative, with the primary purpose of generating meaning (Milestone \& Meyer, 2012:3). This symbolic meaning could be expressed as pictures, morals, performances, individuality or gender (Dansei, 2008; Hermes, 2005; Leventman, 2006). Systems and ideological philosophies affect, create and preserve popular culture, and vice versa (Storey, 2009). The vehicle is often mass media. The next section considers the role of mass media in popular culture, with specific reference to film.

\section{Film as a Component of Popular Culture}

Milestone and Meyer (2012:1) explain that popular culture relies comprehensively on the media, especially mass media such as radio, print media, film, television and the newer digital platforms such as the internet. Mass media products create links between language and images. Milestone and Meyer (2012:17) propose that this makes these media products key ideological forces within popular culture. The media produces symbolic material, but in the process, offers an understanding of the world in the form of messages on and summaries of the consumer's dominant view. Matthews (2003:233) shows that this could cut both ways. Research on the function of the media in children and adolescents' identity development reveals that the media can present encouraging role models for children and adolescents. This exerts a positive influence. However, the media has equal power to offer negative role models, in the process damaging children and teenagers with alarming content. Matthews (2003:220) determines that media representations can have a profound effect on a child or young adult's development of a sense of self. The scope of this chapter does not allow for an exploration of the role of all media within popular culture. As such, film as a component of popular culture receives specific consideration. 
According to Kolker (2016:1), film provides a space where modern people express their stories and myths. People turn to film as entertainment, an escape or for education; it serves as an affirmation of the way society lives or thinks. Valkenburg and Piotrowski (2017:29) explain that in the 1920s, the prevailing notion was that mass media has a significant and uniform influence on the public, regardless of age. This idea was specifically relevant to film and the influence motion pictures could have on the youth. According to Valkenburg and Piotrowski (2017:29), approximately 65 per cent of the US population attended the cinema weekly during the 1930s. Motion pictures provided people, especially the youth, with a new form or entertainment. Jumping to the present, Valkenburg and Piotrowski (2017:2) demonstrate that the landscape of popular culture has changed. Traditionally there was a distinction between old and new media. Film, for instance, would be considered 'old' media, but because of technological advances and changes, new media is repurposing traditional media.

Thus, the changing landscape of popular culture due to technological advances broadens the scope of influence. Beger and Sinha (2012:5) state that in the last ten years, the quantity of mobile connections in Africa has grown an average of 30 per cent per year. The forecast is that it would spread to 735 million by the end of 2012 . South Africa contributes the third largest sum of mobile subscribers, after Nigeria and Egypt, and young people are the prime users of mobile technologies in South Africa. Young people between the ages of 15-24 make up nearly 72 per cent of mobile ownership (Beger \& Sinha, 2012:6). This opens the way for streaming platforms like Nefflix and Apple TV, which distributes not only films, but series, documentaries, reality shows, news, to mention a few (Valkenburg \& Piotrowski, 2017:2). This brings an older medium, film, back into sight. Beger and Sinha (2012:6) explain that this availability of multiple popular culture platforms amplifies the freedom the youth has to express themselves and at the same time heightens the exposure to dangerous ideological notions. Many factors influence how we produce symbols. There is structure to how we understand the world, a lens that governs the meaning that originates with symbols. Popular culture and media as an example, has become an alternative ideological perspective as a means to view and engage with society (Milestone \& Meyer, 2012:1). Within the broader category of mass media, film serves as a powerful medium for meaning-making.

\section{The Influence of Film on Teen Masculinity}

Films can make significant contributions to the definition of the world around us and therefore the definition of ourselves. Ligensa (2009:244) remarks that the socialising power of film unfolds below the level of concepts, language and 
reflection. It allows spectators to gain distance from their ordinary living conditions. This is vital for individuals in the sense that it can create the illusion of community. For those in community, film can introduce the cosmopolitan experience of new people and places (Ligensa, 2009:244). It creates a new universality and offers a new kind of uniformity, which fundamentally synchronises the perception of isolated individuals (Ligensa, 2009:244).

Davis (2018:1) explains that films based on comic books have emerged as a major film genre. Davis (2018:2) illustrates that this specific film genre not only thrives for cultural and technological reasons, but cinematic superheroes have in many ways become a form of exploring identity and politics using themes of heroism, militarism and cultural transformation. Recent film studies focus on discourse analysis, which suggests a systematic functional-linguistic-based multimodality for the enquiry of film. This approached is founded on the transformation of film from entertainment to social engagement and practice, highlighting the complex communicative nature of film. Film becomes a multifaceted and ongoing social event, a theme for philosophical explorations into forms of art and meaning-making (Cloete, 2017; Starc, Jones \& Maiorani, 2015). The textual quality of film guides the meaning-making process of viewers during the reception and evokes interpretive inferences as grounding elements of the narrative comprehension (Wildfeuer, 2014:1). Meaning in film emerges from multiple interactions between various modalities (language; imagery; music; script; artistic expression; audience engagement, etc.). The interplay of these modalities result in a narrative text where comprehension and interpretation requires the spectator's active participation (Wildfeuer, 2014:1)

Superman, both as a comic book and film character, provides the opportunity to engage with film as narrative text and as a source of meaning-making, which may have an impact on the interpretative process of adolescent masculinity. Superman as a character has evolved for seventy-five years, all the while providing relevant social commentary. It has been adapted to the screen in various films, reflecting the multiple interpretations. Superman has remained relevant as a result of this continuous process of updating. He has the capability to transform himself according to societal contexts while succeeding in projecting the impression of unchanged virtues (Harris, 2013). Technological advances have helped this comic book character to embrace a new life in the cinematic universe. The 2013 release of the film Man of Steel reinvigorated the character's popularity as mythical legend and hero.

Superman means different things to different people: for some he serves as encouragement, for others he is a foreigner, a refugee from a another planet looking to serve, an American soldier struggling in the war for truth and justice, etc. 
Eco (1984:107) describes Superman's abilities as "... practically unlimited, he can fly through space at the speed of light, and he has X-ray vision and super hearing, he is also kind, handsome, modest and helpful. "Noteworthy in the character's history is the creators of Superman's story and the contextual rationale that influenced the construction and depiction of his masculinity. Jerry Siegel and Joe Shuster created this character in 1934, envisioning an amalgam between Samson, Hercules and all other strong men ever known (Babka, 2008:119). Shuster was accountable for Superman's build. Like Siegel, he was a fan of pulp fiction and bodybuilding magazines, saying: "I was really small, and I was always pushed around by bullies and so forth so that was one of my dreams ... I took courses in weightlifting and bodybuilding and I don't know if it helped, but I made an effort." (Secret Origins: The Story of DC Comics, 2010) The Superman character became Shuster's expression of who he was, reflected in Clark Kent (as the weaker although virtuous alter ego of Superman), but also who he wanted to be (Paris, 2011:13). This served as a motivation to engage with the interpretive outcomes of the character and how it can be linked to adolescent masculinity. The character in its complexity is often depicted as a binary where Superman is the dominant male and Clark Kent is the subordinate. This representation, born from the fantasy or ideal of two adolescent males that subjected their own understanding of masculinity to the societal binary within the hierarchy of masculinity, is reflected in the comic book character. The interpretation of Superman as filmic text thus becomes a site that may influence adolescents during their process of establishing an understanding of embodied masculinity. They look up to him, they emulate him, and they may even see a glimpse of him in the mirror (Paris, 2011:4).

Darowski (2012:66) enlightens us on how these two comic book creators essentially upheld hegemonic masculinity as the model gender order. This has also translated to the cinematic universe of superheroes. Popular culture has become an important role player in the construction, maintenance and classification of masculinity, yet it is filled with stereotypes of hegemonic masculinity (Johnson, 2014:70). Johnson (2014:71) has the hope that understanding the consumption of popular culture would give us an understanding of how it puts forward beliefs about masculinity. Symbolic systems undergird beliefs, and widely accepted beliefs translate into an accepted universal interpretation of masculinity. Johnson (2014:71) argues that the defined modern masculinity is strengthened by demand and adherence to the messages propounded by popular culture and internalised by adolescents.

Superman's body is that of a strong, white, heterosexual, hegemonic male (Babka, 2008; Daniels, 1995; Darowski, 2012; Eco, 1984; Mcquillan, 2014). Millington and Wilson (2010:1672) specify that while the media exemplifies varied masculinities, research has discovered that power, violence in the name 
of good and heterosexuality are characteristically depicted as the norm. Despite the development of masculinities over the last decades, popular culture still holds to dominant masculine traits. The media representation of dominant masculine traits allows little space for femininity and alternative masculinities (Millington \& Wilson, 2010:1672).

Media users may take inconsistent and conflicting meanings from these portrayals of dominant masculinities as they react with traditions, people and social standing. For the adolescent male, the proposed male ideal may normalise specific masculinities (Millington \& Wilson, 2010:1673). Yet what makes the character fascinating is the realisation that Superman and Clark Kent are the same person. Therefore, it is possible to embrace the existence of both dominant and subordinate masculinities within one character. The concern then arises when more focus should be placed on the dominant exertions of hegemonic and hyper-masculinity. Superman as a narrative text becomes a source that influences the semiotics and ideologies that could impart the idealisation of representing hegemonic masculinity among adolescents. The exemplifications of a binary masculinity that neglects to integrate Superman as 'ultimate hero' and Clark Kent as the 'ordinary' reporter, furthers the systemic and ideological hierarchy found within the matrix of masculinities. Superman becomes a means to engage with the complexity that exists in defining and embodying masculinities. The ideal is to start a discussion that creatively challenges the binary without creating a new norm for masculinity. This is in line with Butler's (1990:18) suggestion that it is imperative to explore the assertions of a masculinist signifying economy, but also to remain self-critical with regard to the gestures of feminist criticism. The attempt to pinpoint the enemy as singular in form is a contrary discourse that indecisively imitates the approach of the oppressor instead of offering a different set of terms. This also informs the decision to participate theologically with different views of masculinity, while refraining from explicitly pinpointing a precise alternative. The following discussion keeps in mind the complex nature of engaging with multiple semiotic and ideological interpretations of masculinities.

\section{The Need for Alternative Views of Masculinity: A Theological Perspective}

The developmental process we call adolescence is a constant state of integration and evolution, especially when it comes to adolescent masculinity. Researchers (Cunningham \& Meunier, 2004; Millington \& Wilson, 2010) have pointed out that male adolescents' experience a severe burden to conform to the social ideals of hegemonic masculinity constructions that impact their reasoning, emotive and 
physical progress. Film, serving as a socialising agent and using Superman 'The Man of Steel" as an example, promotes specific masculine behaviours that create a difficult to achieve standard. The question is then how practical theology could aid in addressing the challenges that male adolescents experience. Practical theology engages with social sciences to understand the lived experiences of humanity, making practical theology interdisciplinary by nature (Miller-McLemore, 2012:472). It is a space where religious beliefs, custom and practice intersect with contemporary understandings, enquiries and activities. It also establishes a dialogue that can be enriching, intellectually critical and practically transforming. Practical theology engages with questions related to faith and tries to understand praxis empirically to produce a theological framework with which to gauge representations of practice for potential conduct and improvement (Osmer, 2006:329). According to Smith (2008:203), practical theology refers to the application of theology to life and ministry. Smith (2008:204) explains that a distinguishing element of practical theology is that it strives to utilise theological thought to solve real-life problems, thus its starting point is a problem in the real world, a real-life situation that is not as it should be.

Ballard (2012:164) reasons that practical theology finds its embeddedness in the theological task in a contextual method. Therefore, practical theology is a system of undertaking theology that takes into consideration the spirit and message of the Gospel, the Christian tradition, the culture in which theology is being practiced and the modifications that take place in the said culture ( $p .164)$. Practical theology has a responsibility to theological undertakings and to biblical studies to comprehend how the Bible is recognised and regarded in church and in the world (p.170). Thus, practical theology provides a helpful framework to engage with the socialising power of film and how it impacts the masculinity construction of male adolescents. The interdisciplinary discussion and engagement with social sciences on popular culture with a focus on the socialising power of film by using the example of Superman, it becomes evident that film can have a negative influence on adolescent masculinity. This is a real-life problem that necessitates a practical theological engagement to formulate representations of masculinity that are inclusive and to break the notion and embodiment of dominant, hegemonic masculinity.

Building on the interdisciplinary nature of practical theology enables both the partnership and engagement of practical theology and feminist theology of praxis as dialogue companions. Feminist theology of praxis is grounded in the discipline of practical theology, but it provides a feminist perspective on moral questions such as sexuality, reproduction, violence against women and children, the relationship between women and men and between human beings and nature 
(Ackermann, 2006:277). Stemming from feminist theory and feminist theology, a feminist theology of praxis enables the identification and liberation of all broken people from the effects of patriarchy (Jones, 2000:14). This viewpoint comprises people who find themselves on the outskirts of civilisation and who experience the profane consequences of discrimination. This is the case with male adolescents who do not fit into the prescribed notions of hegemonic masculinity - the Superman ideal. At this point it is imperative to note that although the discussion focusses on male adolescents, it does not disregard the life-denying effect patriarchy has on women. A feminist theology of praxis enables this conversation on the effects of the hegemonic ideal on all parties influenced by it. Practical theology and feminist theology encourage the consideration of alternative notions of masculinity, thus addressing the question: "How can practical theology aid in addressing the challenges that male adolescents experience with the hegemonic ideal Superman presents?"

Film disseminates an idealised hegemony that points to the notion of dangerous masculinities (Chitando \& Chirongoma, 2012). Patriarchy and hegemony undeniably affect all of humanity and there should be particular consideration of the actuality that these constructions obstruct on the humanity of women and children and men that exist on the margins (Jones, 2000; Koopman, 2004; Oduyoye, 2001; Van der Watt, 2007). Thus, it is necessary to search for alternative conceptions of masculine constructions. Owino (2010:2) suggests that we should closely consider the societal, spiritual and cultural productions of masculinities, with the goal of conceptualising alternative masculinities. Owino (2010:2) argues from a theological perspective of hope grounded in the transformative missiological paradigm, thereby challenging the dehumanisation of dominant masculinities. This entails a deliberate theological outlook that will infer masculinities with life-giving realities (Chitando \& Chirongoma, 2012; Owino, 2010).

Koopman (2004:197) suggests that a comprehensive consideration of humankind with regard to rationality, dependence and vulnerability could offer the possibility of coming to terms with the isolation that both men and women experience. By re-assessing what our humanity signifies, we are able to explore the notion of expedition of re-humanisation (Koopman, 2004:197). Dube (2016:2) postulates that alternative masculinities can be utilised as a means to oppose cultural designs of significance that propagate patriarchy and hegemony. It can also be used to challenge the economic inequality that encumbers the human dignity of persons (Dube, 2016:2). Alternative masculinities encourage differentiated perspectives of sexuality while opposing the essentialism of cultural and societal expectations of what it entails to be a man (Dube, 2016:2). Oduyoye (Dube, 2016:3) recommends the 
idea of Jesus Christ as the mother in an effort to exemplify alternative masculinities from African women's theology, thereby promoting the deconstruction of patriarchy and calling for new images of manhood based on care and love (Dube, 2016:3).

An alternative perspective regarding masculinities considers transformative masculinities based on the social vulnerabilities of men (Van Klinken, 2012:215). This entails that we utilise religion and culture to serve as catalyst for transformative masculinities, thereby challenging the socially, culturally and historically constructed masculinities (Togarasei, 2013:2). Transformative masculinities pursue the goal of encouraging boys and men to make meaningful contributions to more supportive and life-giving ideas about what it entails to be a man (Chitando, 2012a:7). This can facilitate a conversation and identification of negative and dangerous ideas subject to social and cultural expectancies (Chitando, 2012a:7). Chitando and Chirongoma (2012:6) emphasise that hegemonic masculinities depict men as having authority over women and children, but this is not always the case. Not all men have that power, and under societal pressure some men start to behave in a domineering and sexually violent way. The connection concerning masculinities and (hetero-) sexual presentation is entrenched and bolsters the categorised edifice of dominant to lesser peripheral masculinities (Chitando \& Chirongoma, 2012; Connell, 1995, 2005; Messerschmidt, 2016).

One of the key influences on the formation of masculinities that have been overlooked in existing scholarly reflections, is religion (Chitando \& Chirongoma, 2012:7) The two major reasons for this neglect points firstly to the researchers who have remained forerunners in this area who is not knowledgeable in theology and religious scholarships. Secondly, African women theologians who generate a discourse on gender are more specifically focused on the liberation of women and children, resulting in deficient theological and religious consideration of masculinities (Chitando \& Chirongoma, 2012:7). Chitando and Chirongoma (2012:7) emphasise the significant influence of religion and theology in shaping and confronting damaging masculinities. They further (2012:28) explain that masculinities have the capability to change and adapt. The influence of hegemonic masculinity, which is propagated by the socialising power of film as a component of popular culture, and the damaging magnitude of the hegemonic norm for male adolescents' humanity and for society requires the development of redemptive masculinities. Chitando and Chirongoma (2012:1) encourage the concept of redemptive masculinities, proposing that society does not perceive men as superheroes who appear in critical moments and save the day, but rather as persons who participate with redeeming masculinities to move away from the dominating norm. Chitando and Chirongoma (2012:1) incorporate and utilise the notion of 
redemptive masculinities to represent and identify masculinities that are 'life-giving' in a world that is experiencing anguish from the cost of violence and AIDS. This notion encompasses the importance of developing masculinities that encourage the health and well-being of all. All the suggested contributions regarding masculinities (Chitando \& Chirongoma, 2012; Dube, 2016; Koopman, 2004; Owino, 2010; Togarasei, 2013; Van Klinken, 2012) refer to a fundamental theme - the importance of humanity. It encourages the deconstruction of the life-denying and dehumanising consequences of patriarchy and hegemony. Practical theology and feminist theology of praxis engages with the notion of hegemonic masculinity that creates difficult standards to achieve and in doing so perpetuates an exclusive norm of masculine behaviour and embodiment among male adolescents. This engagement enables the process of identifying masculinities founded on theological understandings of masculinity to arrive at inclusive, alternative, transformative and redemptive constructs of masculinity. Furthermore, practical theology and feminist theology of praxis enables the recognition of spaces in need of alternative theological views.

\section{Spaces in Need of Alternative Theological Views}

\section{Family}

As established, film as a socialising agent influences the masculinity construction of male adolescents, creating a negative ideal of hegemonic masculinity that necessitates an alternative theological perspective on masculinities. This also indicates spaces in need of alternative theological views. The first sentence points toward the family of male adolescents. Chambliss and Eglitis (2014:79) explain that family plays an imperative role in communicating standards, morals, ethics and culture across generations. Zain and Yew (2014:294) concur that parents function as role models in the familial context, affecting growth and behavioural responses in adolescents. Gentry and Campbell (2002:23) remind us to take into account that the notion of family may consist of diverse family structures: single, divorced, adoptive, foster and the traditional two-parent relationship. This is particularly important when considering the family demographics of South Africa. The nuclear model of family in South Africa is influenced by several elements, such as the history of Apartheid and the travelling labour system, absent fathers, poverty and the HIV/Aids epidemic (Holborn \& Eddy, 2011:1). These elements leave male adolescents with single parents or as orphans (Ibid.).

The space of family therefore necessitates alternative theological perspectives on masculinity. The diverse family constructs in South Africa provide the opportunity to formulate differentiating notions of masculinities. De Kock, Elhorst and Barnard (2015:156) suggest that parents are identified as a target group that have not 
received sufficient attention and has the potential to contribute to teaching adolescents about the Christian faith. This space can be used as a reciprocal learning endeavour for both male adolescents and parents, thereby challenging the construct of hegemonic masculinity. Cloete (2016:2) explains that the family is a hermeneutical locus where adolescents can come to accept themselves, others, the world and God. The formative power of the family can greatly influence how male adolescents construct their masculinity. The reality of the context of South Africa where male adolescents are faced with poverty, orphan-hood, HIV/Aids and the absence of one or even both parents (Holborn \& Eddy, 201 1:1), suggests that these adolescents will look to alternative role models for their development of masculinity constructions, for instance teachers. The influence of teachers suggests the second space in need of alternative theological perspectives on alternative, transformative and redemptive masculinities.

\section{School}

Gentry and Campbell (2002:24) explain that school is an important part of adolescents' daily lives. The school environment provides the possibility for male adolescents to establish peer and teacher relationships. In the absence of parents, the school setting could offer safety and stability, thereby producing the likelihood of bonding with teachers (Holborn \& Eddy, 2011). Zain and Yew (2014:294) use the notion of the role model to demonstrate the impact teachers can have on representations of masculinity. This suggests that male adolescents will reproduce their behaviour to match individuals who encourage and influence them (Zain \& Yew, 2014). The actions of teachers can reproduce characteristics that can influence the development of both dominant and alternative masculinity constructions.

White and Hobson (2015:905) explain that traditionally the leading model of masculinity was reproduced among male adolescents in the context of the school environment, and more specifically on the sport field, ensuring a classification of repeated struggle in an attempt to reach the fortunate sphere of the gender order. This points towards the need for male adolescents to achieve the hegemonic masculine ideal. However, White and Hobson (2015:905) note that the shift in male stratification in sport, education and youth culture in this social milieu allowed for more accepting attitudes towards both sexual multiplicity and the recognition of wider gender performances. Within the scope of the school environment and based on White and Hobson's (2015) assessment of the changing landscape regarding gender on the field, teachers could provide both the formulation and embodiment 
of inclusive masculinities. Therefore, teachers as role models have to be equipped with alternative theological views on masculinities. In addition to this, the school environment is a space where adolescents develop peer relationships.

\section{Peer Relationships}

Chambliss and Eglitis (2014:86) explain that peer relationships play an imperative role in behavioural patterns, including the development of self-esteem and self-image. Gentry and Campbell (2002:21) demonstrate that peer groups provide a number of important roles that become the fluctuating points of orientation when forming an identity. During their connection with a peer group, adolescents begin to develop moral discernment and values (Gentry \& Campbell, 2002:21). Peer groups also function as a source of information beyond the circle of family life, thus influencing the development of identity in adolescents (Gentry \& Campbell, 2002:21). Peer groups also affect the behavioural patterns, especially when parents are absent, leading to the need to conform to certain societal standards. Peer pressure perpetuates norms that are established within the group. This can especially be seen among adolescent males. The perceived hierarchy of masculinity is emulated within the peer group dynamics. This can be both a space for developing negative and positive notions of masculinities. Selikow, Ahmed, Flisher, Mathews and Mukoma (2009:107) remark that South African adolescents are enormously susceptible to the dangers of HIV-infection and that peer pressure may encourage high-risk sexual behaviour during the phase of sexual experimentation (Selikow et al., 2009:107). Comprehending the motivating forces of peers as socialising agents could aid with the edification of adolescents and the modification of negative peer pressure (Selikow et al., 2009).

\section{Religion}

Religion is also an imperative part of many people's lives, teaching essential values and beliefs that add to a communal and normative culture. Historically, theological and church institutes conform to the patriarchal male-dominated hierarchy (Schüssler Fiorenza, 1975:612). As a source of influencing the notions of masculinity, the church is a space that is in critical need of alternative theological masculinity constructions. Koening-Visagie and Van Eeden (2013:9) explain that mainstream media and churches, focusing specifically on the Dutch Reformed Church, show a representational preference of dominant masculinity. Hegemonic or dominant masculinity is also embedded in representational practices and seen in churches that participate in Western conceptions of masculinity (i.e. white, heterosexual and dominant) (Koening-Visagie \& Van Eeden, 2013:10). This 
masculine ideal is upheld to congregation members by giving it representational priority and lending it legitimacy through signification. Van Staden (2014:34) explains that Afrikaner masculinity in the Dutch Reformed Church is shaped by the complex intersecting factors of church and culture. The Afrikaner religion also plays a huge role in the establishment of patriarchy in all spheres of life based in biblical texts (Van Staden 2014:36). This influenced the development of hegemonic Afrikaner masculinity that marginalises alternative masculinities by quieting and stigmatising them (Du Pisani, 2001:157). With the changing landscape of South Africa, starting with the abolishment of Apartheid, the notion of Afrikaner masculinity is still in the process of being redefined. Van Staden (2014:37) explains that these radical changes and loss of power cause men to hold on to the perceived power in the sphere of the church and at home. This also influences male adolescents' emulation of hegemonic masculinity. The church as a space that perpetuates this dominant notion of masculinity further marginalises masculinities that do not fit in to the societal 'notions' of masculinity.

This necessitates alternative, transformative and redemptive masculinities that can aid male adolescents who are pushed to the periphery of society, in this case in the Dutch Reformed Church. Alternative, transformative and redemptive masculinities challenge the dehumanising consequences of patriarchy and hegemony. Alternative masculinities can be utilised to oppose the patterns of meaning found in systems of patriarchy and hegemony and can offer a critique of cultural and societal essentialism. The focus should be on innovative ways of perceiving the ideas that influence thoughts and the embodiment of masculinity. Transformative masculinities consider the social vulnerable way of enabling a change in masculinity constructions and inspire men and male adolescents to participate in changing their attitudes towards women, children and other men. The concept of redemptive masculinities advocates for a process of deconstructing dangerous masculinities perpetuated by patriarchy and hegemony as a way to liberate and transform men. The spaces of family, teachers, peers, and film intersect and engage in various ways that cannot be neglected or discredited. The spheres of influence regarding masculinity constructions overlap and affect one another, although the main focus of this discussion is the socialising power of popular culture and film as a component of popular culture. It is imperative to be aware of the tension between these spaces. The development of masculinities that are alternative, transformative and redemptive is dependent on a joint effort from families, teachers, peers and churches. The fascination with superheroes, in this case Superman, promotes adherence to hegemonic masculinity, but beyond the cultural constructs that constrict Superheroes to defined characteristics, these characters can also inspire us to be better, to be more inclusive, to change the narrative of our own stories for the greater good of humanity. 


\section{Conclusion}

This chapter discussed the theoretical concepts of popular culture, extending to film as a component. This illustrates that popular culture has symbolic meaning that is expressed as images, values, behaviours, identity development or gender, and which is further integrated with systems and ideological constructs. Specific attention was given to the popular culture medium of film, demonstrating the socialising power of film and how it affects the notion of masculinity and the embodiment of masculinity. The example of Superman proves that film socialises male adolescents to adhere to hegemonic masculinity, which creates and ideal that is difficult to achieve for young men who are still developing their individual identity. Practical theology and a feminist theology of praxis point to the need for alternative theological perspectives on masculinities that are more inclusive. This illustrates the need for alternative, transformative and redemptive masculinities that address life-denying effects of patriarchy and hegemonic masculinity. The chapter concludes that the space of family, teachers, peers and the church are in dire need of these alternative understandings of masculinities to aid male adolescents who are pushed to the periphery of society. This highlights the need to engage aspects of society that perpetuate exclusive, dehumanising and negative notions of masculinities and to work towards a society that embraces life-giving and liberating masculinity constructions for all.

\section{Bibliography}

Ackermann, D.M. 2006. From mere

existence to tenacious endurance: Stigma,

HIV/AIDS and a feminist theology of praxis.

In: I.A. Phiri \& S. Nadar (eds.), African women,

religion and health: Essays in honor of

Mercy Amba Oduyoye. Pietermaritzburg:

Cluster Publications. pp.221-242.

Anderson, M.L. \& Taylor, H.F. 2008. Sociology: Understanding a Diverse Society, Media and Research Update. 4th Edition. United Kingdom: Wadsworth Publishing Company.

Babka, S.P. 2008. Arius, Superman, and the Tertium quid: When popular culture meets Christology. Irish Theological Quarterly, 73(1-2): 1 13-132. https://doi. org/10.1177/0021140008091695

Ballard, P. 2012. The Use of Scripture. In: B.J. Miller-McLemore (ed.), The Wiley-Blackwell Companion to Practical
Theology. West Sussex, UK: Blackwell Publishing. pp.163-172.

Beger, G. \& Sinha, A. 2012. South African Mobile Generation: Study on South African Young People on Mobiles. UNICEF. [Online]. Available: https://uni.cf/30r8LI2

Butler, J.P. 1990. Gender Trouble: Feminism and the Subversion of Identity. New York: Routledge.

Butler, J. 2004. Undoing gender. Boca Raton, [Fla.]: Routledge, Taylor \& Francis Group.

Cloete, A. 2016. Revisiting a family approach in youth ministry, In die Skriflig, 50(1):a2078. https://doi.org/10.4102/ids.v50i1.2078

Cloete, A.L. 2017. Film as Medium for Meaning-Making: A Practical Theological Reflection. HTS Teologiese Studies/Theological 
Studies, 73(4):a4753.

https://doi.org/10.4102/hts.v73i4.4753

Chambliss, W.J. \& Eglitis, D.S. 2014. Discover Sociology. Los Angles: Sage Publications.

Chitando, E. 2012a. Transformative Masculinity: Bringing Men into the Struggle against Sexual and Gender-Based Violence. In: E. Chitando \& N.J. Njoroge (eds.), Contextual Bible Study Manual on Transformative Masculinity. Harare: The Ecumenical HIV and AIDS Initiative in Africa. pp.6-8.

Chitando, E. \& Chirongoma, S. 2012. Redemptive masculinities: Men, HIV, and religion. Geneva: World Council of Churches Publications.

Connell, R.W. 1995. Masculinities. Cambridge, UK: Polity Press.

Connell, R.W. 2005. Masculinities. 2nd Edition. Cambridge, UK: Polity Press.

Cunningham, M. \& Meunier, L.N. 2004. The influence of peer experiences on bravado attitudes among African American males. In: N. Way \& J.Y. Chu (eds.), Adolescent boys: exploring diverse culture of boyhood. New York: New York University Press. pp. 197-218.

Daniels, L. 1995. In Secret Origins: The story of DC Comics. Carter, M. (dir.). [Online]. Available: http://7torrents.top/Movies/ Download2.aspx?id=1005115

Dansei, M. 2008. Popular Culture: Introductory Perspectives. 3rd Edition. United Kingdom: Roman \& Littlefield Publishers.

Darowski, J.J (ed.). 2012. The ages of Superman: Essays on the man of steel in changing times. New York, NY, United States: McFarland \& Co.

Davis, B. 2018. Quick Takes Movies \& Popular Culture: Comic Book Movies. USA: Rutgers University Press. https://doi.org/10.2307/j. ct1227281j
De Kock, J.; Elhorst, W. \& Barnard, M. 2015. The Comeback of Parents in Catechesis Practices in Journal of Youth and Theology, 14 (2015): 155-171. https://doi. org/10.1163/24055093-01402003

Dube, Z. 2016. 'The African Women Theologians' contribution towards the discussion of alternative masculinities. Verbum et Ecclesia, 37(2):a1577. https://doi.org/10.4102/ve.v37i2.1577

Du Pisani, K. 2001. Puritanism Transformed. Afrikaner Masculinities in the Apartheid and Post-Apartheid Period. In: R. Morrell (ed.), Changing men in Southern Africa. Scottsville. South Africa: University of Natal Press.

Eco, U. 1984. The Role of the Reader: Explorations in the Semiotics of Texts.USA: Indiana University Press, Bloomington.

Gentry, J.H. \& Campbell, M. 2002.

Developing Adolescents: A Reference for professionals. Washington, DC: American Psychological Association.

Gripsrud, J. 2002. Understanding Media Culture. London: Bloomsbury.

Harris, P. 2013. Why is Superman still so popular? The Guardian. New York. [Online]. Available: http://bit.ly/2EexsxA

Hermes, J. 2005. Re-reading popular culture: Rethinking gender, television, and popular media audiences. Malden, MA: Blackwell Publishing. https://doi. org/10.1002/9780470776568

Holborn, L. \& Eddy, G. 2011 . First Steps to Healing the South African Family. Johannesburg: South African Institute of Race Relations.

Johnson, G. 2014. Understanding Masculine Perceptions through Superhero Iconography: Implications for Art Educators. Visual Culture \& Gender, 9:60-72. 
Johnson, J.E. 2015. Influence of Parents, Peers, Internet Products and Visual Social Media on College Student's Purchase Behaviour: A Mixed Method Study. Textiles, Merchandising and Fashion Design: Dissertations, Thesis, \& Student Research. Paper 7. [Online]. Available: http://digitalcommons.unl.edu/textilesdiss/7 [Accessed 26 September 2016]

Jones, S. 2000. Feminist theory and Christian theology: cartographies of grace. Minneapolis: Fortress Press.

Kendall, D. 2010. Sociology in Our Times: The Essentials. USA, Wadsworth.

Koenig-Visagie, L.H. \& Van Eeden, J. 2013. Gendered representations of fatherhood in contemporary South African church imagery from three Afrikaans corporate churches. Verbum et Ecclesia, 34(1),Art.\#760: 12.

Kolker, R.P. 2016. Film, Form and Culture. 4th Edition. Routledge Taylor \& Francis Group: London.

Koopman, N.N. 2004. Theological anthropology and gender relations. Scriptura: Tydskrif vir Bybelkunde, 86:190-200. https://doi.org/10.7833/86-0-948

Koopman, N.N. 2007. The History of Family. Towards a human rights culture in South Africa. The role of moral formation. Dutch Reformed Theological Journal, 48(1) \& (2): 107-118.

Leventman, S (ed.). 2006. American popular culture: Historical and pedagogical perspectives. Newcastle: Cambridge scholars press.

Ligensa, A. \& Kreimeier, K. 2009. Film 1900: Technology, Perception, Culture. United Kingdom: John Libbey Publishing Ltd.

Maiorani, A. 2015. Revisiting Hitchcock: An Alternative Multimodal Reading of Interactive Patterns in Psycho chapter. In: S. Starc, C. Jones \& A. Maiorani (eds.), Meaning-Making in Text: Multimodal and Multilingual Functional Perspectives. England, U.K: Palgrave Macmillan. pp. 134-152. https://doi.org/10.1057/9781137477309_8
Matthews, D. 2003. Media Memories:

The First Cable/NCR Generation Recalls their Childhood and Adolescent Media Viewing. Mass Communication \& Society, 6(3):219-241. https://doi.org/10.1207/ S15327825MCS0603_1

Mcquillan, M. 2014. Superman as an American icon of masculinity. American/consTemple, 10 March. [Online]. Available: http://bit.ly/2Qgys9y

Messerschmidt, J.W. 2016. Masculinities in the making. From the Local to the Global. Maryland: Rowman \& Littlefield.

Milestone, K. \& Meyer, A. 2012. Gender and Popular Culture. Cambridge, UK: Polity Press.

Miller-McLemore, B.J. 2012. The Wiley-Blackwell Companion to Practical Theology. West Sussex: John Wiley \& Sons.

Millington, B. \& Wilson, B. 2010. Context Masculinities: Media Consumption, Physical Education and Youth Identities. American Behavioural Scientist, 53(1 1):1669-1688. https://doi.org/10.1177/0002764210368091

Oduyoye, M.A. 2001. Introducing African Women's Theology. England: Sheffield Academic Press.

Oransky, M. \& Fisher, C. 2009.

The development and validation of the meanings of adolescent masculinity scale. Psychology of Men \& Masculinity, 10(1):57-72. https://doi.org/10.1037/ a0013612

Osmer, R.R. 2008. Practical theology: An introduction. Grand Rapids, MI: Eerdmans.

Owino, K. 2010. Masculinities, HIV and Aids in South Africa - Evaluating the present, mapping the future: Towards a Transformative Missiological Paradigm (A theology of Hope). [Online] Available: http://bit.ly/2HomSX3

Paris, S.M. 201 1. How to be a hero: a rhetorical analysis of superman's first appearance in Action Comics. Published master's thesis. Chattanooga: University of Tennessee [Online]. Available: http://bit.ly/2QiORMq 
Pascoe, C.J. 2005. "Dude, you're a Fag": Adolescent masculinity and the Fag discourse. Sexualities, 8(3):329-346. https://doi. org/10.1177/1363460705053337

Reidy, D.E.; Smith-Darden, J.B.; Cortina, K.S.; Kernsmith, R.M. \& Kernsmith, P.D. 2015. Masculine discrepancy stress, teen dating violence, and sexual violence perpetration among adolescent boys. Journal of Adolescent Health, 56:619-624. https://doi.org/10.1016/j. jadohealth.2015.02.009

Schüssler Fiorenza, E. 1975. Feminist Theology as a Critical Theology of Liberation. Theological Studies, 36(4):605-626.

Selikow, T.; Ahmed, N.; Fisher, A.J.; Mathews, C. \& Mukoma, W. 2009. I am not "umqwayito": A qualitative study of peer pressure and sexual risk behaviour among young adolescents in Cape Town, South Africa. Scandinavian Journal of Public Health, 37(2):107-1 12. https://doi. org/10.1177/1403494809103903

Smith, K.G. 2008. Review of Richard Osmer. Practical Theology: An Introduction. [Online]. Available: http://www.sats.edu.za/userfiles/ Smith_ReviewOsmer.pdf

Storey, J.W. 2009. Cultural theory and popular culture: An introduction. 5th Edition. Harlow, England: Pearson Longman.

Thatcher, A. 2011. God, sex, and gender god, sex, and gender: An introduction an introduction. Malden, MA: John Wiley \& Sons Ltd. https://doi.org/10.1002/9781444396386

Togarasei, L. 2013. Christian and Hegemonic Masculinitiwes: Transforming Botswana Hegemonic Masculinity using the Jesus of Luke. Scriptura, 112:1-12. [Online] Available: http://scriptura.journals.ac.za
Valkenburg, P.M. \& Piotrowski, J.T. 2017. Plugged In: How Media Attract and Affect Youth. New Haven and London: Yale University Press. https://doi.org/10.12987/ yale/9780300218879.001.0001

Van der Watt, J.S. 2007. Images of men and masculinities within cultural contexts: a pastoral assessment. Stellenbosch: Stellenbosch University.

Van Klinken, A.S. 2012. Men in the Remaking: Conversion Narratives and Born-Again Masculinity in Zambia. Journal of Religion in Africa, 42(2012):215-239. https://doi. org/10.1163/15700666-12341229

Van Staden, N. \& Cilliers, J.H. \& Stellenbosch University. Faculty of Theology. Dept. of Practical Theology Missiology. 2014. The Sunday service as a space of nurture towards an alternative masculinity in a context of a lower income white Afrikaans community. Stellenbosch: Stellenbosch University.

White, A. \& Hobson, M. 2017. Teachers' stories: physical education teachers' constructions and experiences of masculinity within secondary school physical education. Sport, Education and Society, 22(8):905-918. https://doi.org/10.1080/1357 3322.2015.1112779

Wildfeuer, J. 2014. Film Discourse Interpretation. New York: Routledge. https://doi. org/10.4324/978020376620

Zain, O.M. \& Yew, S.T.C. 2014. The Relationship of Role Model Perceived Image on Teenagers' Purchase Behavior in Klang Valley, Malaysia A Comparative Study. International Review of Social Science, 2(8):291-308. 


\section{Introduction}

Art and theology seem to share a common ground: both are attempts to imagine the unmentionable. For centuries, art was profoundly Christian. It served Christian faith and church. Roughly, until the nineteenth century art illustrated and commented on what was believed by the faithful. Sometimes it even served the purpose of pure propaganda. Artists collaborated with theologians in order to avoid dogmatic troubles. All this changed in the nineteenth and especially the twentieth centuries. Art became fully autonomous and only served its own purposes (I'art pour l'art). From that moment on, artists illustrated their own faith and commentated that of the churches.

Art and faith became entangled in a love-hatred relationship. When art created its own sphere of transcendence, there was trouble. When artists started to offer their own exegesis of Christian faith - not in line with traditional opinions of churches - bridges were blown up. The list of critical (the churches would say, blasphemous) art works' is long: Francis Picabia (La Sainte Vierge II, 1920), Max Ernst (Die Jungfrau züchtigt das Jesuskind vor drei Zeugen: André Breton, Paul Éluard und dem Maler, 1926), George Grosz (Christus mit der Gasmaske. Maul halten und weiter dienen, 1927), Salvador Dalí (Parfois je crache par plaisir sur le portrait de ma mère, 1929), Man Ray (Pray-La prière, 1930), Andres Serrano (Piss Christ - Immersions, 1987), Maurizio Cattelan (La Nona Ora, 1999) and so on (Follet, 2008: 233-236; Bonfand, 2008: 240).

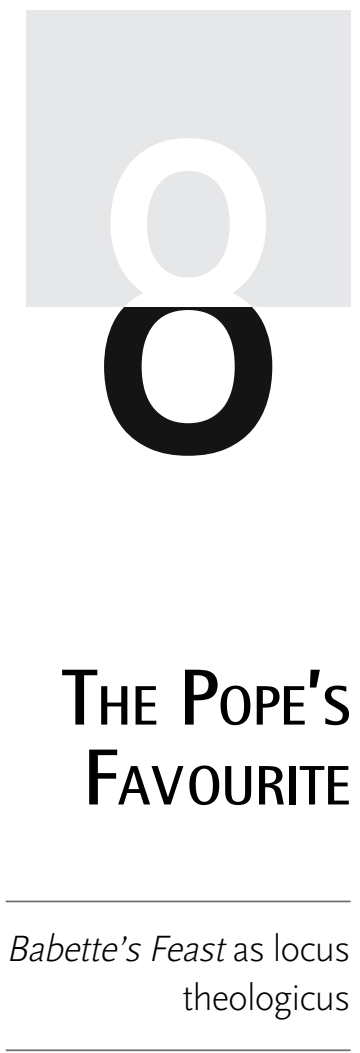

Hans Geybels 
It remains a harshly debated question whether all these artefacts are really blasphemous. It is not always certain whether the artist had the explicit intention to hurt the church, the faithful or both. The Piss Christ of Andres Serrano - an agnostic American artist - reveals something about incarnation in a way a text source is hardly capable of. The same is true of his The Other Christ and of The Interpretation of Dreams (2001), which depicts a black Christ in the arms of a white Mary. Serrano clearly created beauty with this picture, but he also questions Christian presuppositions. At first glance, Serrano is provocative, but once it is clear that he has no intention to shock, his art is able to reveal something profound about Christianity.

Christian art - whatever this may be - is capable of revealing something of transcendence. In traditional terminology: it can function as a locus theologicus. In this contribution, I focus on one particular work of art: the film Babette's Feast. In 2016 Pope Francis declared it to be his favourite movie, but if we consider the movie to be a locus theologicus for the theology of the Eucharist, the pope may have far-reaching ideas about the real presence of Christ in the Eucharist.

\section{Synopsis of Babette's Feast}

In the nineteenth century, in a small Lutheran village on the desolate coast of Jutland (Denmark), a charismatic and authoritarian pastor leads his sectarian community with a pious and austere life. He has two pretty daughters, Martina and Philippa (named after Martin Luther and Philip Melanchton), whom he does not want to lose at any price to the chagrin of the young men of the village.

Lorens Löwenhielm, a young officer at the Guard Hussars who is sent into the area for punishment for three months, falls deeply in love with Philippa, but despite all his efforts to integrate into the family circle, he has to leave alone. With a broken heart, he swears to devote himself solely to his military career. Martina is spotted by Achille Papin, a French baritone at a holiday resort, who immediately sees in her a future diva who could have all of Paris at her feet. After several months of private lessons and despite progress, it is Martina who puts an end to their nascent relationship, to the great satisfaction of her father. Thirty-five years later, the pastor is dead and the two sisters are still single. They try to lead a divided congregation, in which members envy one another.

One stormy night, an exhausted woman knocks on their door. It is Babette Hersant, a French gourmet chef, who asks them for refuge, offering her services as a house cleaner. She has a letter of recommendation from Achille Papin, who explains that 
she had to flee the civil war of the Paris Commune in 1871. The best reference Papin can give, is that she "knows how to cook". Martina and Philippa accept her, even though they cannot afford it financially. Babette learns Danish and the local cuisine. For fifteen years she serves the two sisters with humility, enabling them to devote themselves to helping the poor of the region and to serving their faith community.

Babette's single link with France is a lottery ticket for which a friend pays each year. One day Babette receives a letter from France informing her that she won the jackpot of 10000 francs. In a moment, she has become rich. The elderly sisters fear that their maid will return to France, but instead, she proposes to prepare a splendid French meal on the occasion of the centenary of the birth of the late pastor. There will be twelve guests, including Lorens, who has become a general. Babette is absent for several days to bring the necessary ingredients by boat and prepare the meal.

Just a few days before the lavish dinner will take place, Martina and Philippa realise that this meal is not at all consistent with their ascetic religious convictions and the awareness gives them nightmares. It is too late to retreat, because everything has been prepared. So the community unanimously decides that during the entire meal, they will not make any comments about the luxurious food. They will remain silent, and so doing honour their ascetic convictions.

The sequence of the feast lasts for half an hour. At the table Lorens discovers with amazement and emotion the exceptional quality of the dishes and wines that Babette serves: potagé à la tortue, caviar blinis, and caille en sarcophage, a chef d'oeuvre created by Babette. Each course is complemented by the most exquisite wines and champagnes. The general breaks the silence and allows himself to express his wonder fully and freely. He says that once, at the Café Anglais in Paris, he was able to taste exactly the same dishes. They were original creations of a renowned chef, he had been told. Despite their initial reluctance, the other guests start to voice their amazement as well, the alcohol loosening their tongues. By the time coffee is served, the tensions between the divided community are resolved and everyone is reconciled. Lorens sees in this meal a message of divine grace after all the years in which he thought that his choices had led to his whole life being a failure.

The two sisters thank Babette wholeheartedly. They are preparing for her departure, but Babette tells them she will stay. She no longer has ties with Paris, and no more money, because she spent everything on this single meal - 10000 francs was the price of a meal for twelve at the Café Anglais, where she once worked as a chef. 
Babette's Feast is directed by Gabriel Axel and based on a Danish novella by Isak Dineson (born Karen Blixen). The film is on the list of quality movies that the Vatican issued in 1995 in the centenary year of cinema. It won the Oscar for Best Foreign Language Film in 1987.

\section{Interpretation}

Babette's Feast is like a gospel: it is multi-layered and provokes a plethora of opinions and interpretations. One of the best theological commentaries on the film was written by Thomas J. Curry, a teacher at St. John's College, a Lassalian preparatory school in Washington DC (Curry, 2012:1-40). He attempts to answer one of the preeminent questions the movie provokes: Why does Babette spend 10,000 francs (everything she has) to create a feast for others? Why does a Catholic spend all her money on one dinner in remembrance of a Protestant sect leader? Other interpretations, like feminist ones (Goodwin, 1990; Poddles, 1992) are possible, but I will focus on theology, more in line with Pierre Bühler (1998) and Wendy M. Wright (1997).

Curry pays little attention to the question whether Babette resembles Christ or whether her feast might be compared to a Eucharist. Instead, he focuses on the violence in Babette's life, of which the viewer gets only hints in the background of the movie. Curry argues that the planning, the preparation, and the service of the meal is a process through which the French cook is reconciled with her violent past.

Curry carefully examines four crucial scenes. The most important one is the fourth, revealing Babette's deepest motivation for offering her feast. The former cook has cashed in her lottery ticket. She sits on a chair in profile in her room (the images reflect the famous painting Artist's Mother by Whistler, painted in 1871). Suddenly, we get a close-up of her bedside. Just above her pillow, we see a picture of what must be her late husband and a timepiece (probably her husband's), banded by a blue-blanc-rouge ribbon. After this scene, we see her standing at the sea shore, staring in the distance. A lone white bird passes over the sunlit, blue water. Babette turns around and walks decisively back home. She has made a decision: she will spend her entire fortune on a memorial meal. I think Curry is right: the feast will not only commemorate Martina's and Philippa's father, but also her Babette's husband and her son, who both died during the Communard uprising. She could flee Paris, unlike her husband and son. But she could not even bury them.

In this way, the feast also becomes a burial meal. This is supported by the symbolism of Babette's chef d'oeuvre: cailles en sarcophages (quails in sarcophagi), a single quail wrapped in pastry (the 'sarcophagus'). It becomes clear why we had to 
witness the rough plucking and skinning of the quail when she was preparing her meal - the process imitates the bloody and violent death of her family in Paris. What is more, caille in French is a term of endearment, "Ma petite caille" means much the same as "my darling". That is why she greets the quails when they arrive by boat from France with the words: "Alors, mes petites cailles." Finally, she is able to mourn and bury her family, be it symbolically. The feast is redemptive. God's goodness prevails in spite of every evil.

\section{The Pope's favourite}

For the first time in history, a pope - Pope Francis - has referenced his favourite film in a papal document. Amoris Laetitiae (English: The Joy of Love) is a post-synodal apostolic exhortation addressing the pastoral care of families. The document-dated 19 March 2016 - follows the Synods on the Family held in 2014 and 2015. It covers a wide range of topics related to marriage and family life and includes an extended reflection on the meaning of love in the daily reality of family life. In chapter 4, number 129 (Pope Francis, 2016:no.129), we read:

The joy of this contemplative love needs to be cultivated. Since we were made for love, we know that there is no greater joy than that of sharing good things: Give, take, and treat yourself well (Sir 14:16). The most intense joys in life arise when we are able to elicit joy in others, as a foretaste of heaven. We can think of the lovely scene in the film Babette's Feast, when the generous cook receives a grateful hug and praise: Ah, how you will delight the angels! It is a joy and a great consolation to bring delight to others, to see them enjoying themselves. This joy, the fruit of fraternal love, is not that of the vain and self-centeredness, but of lovers who delight in the good of those whom they love, who give freely to them and thus bear good fruit.

The fact that this movie is the pope's favourite, most certainly has nothing to do with hidden Catholic propaganda. "Are you a papist?" the fun-loving tenor of Catholic France asks when he arrives in the little Danish village and meets Philippa 150 years ago. And of course, he is not allowed to marry Philippa.

It has more to do with the new inhabitant of the village. She is at the root of a dialectical move: the commemoration of the 'founding father' of the small community and the opulent feast. Gluttony is a despicable thing for Protestant ascetics, but she humbly forces them to the table, where they succumb to the sensual joy of a Catholic tradition. Babette reminds the pope of the Jesuit principle of alter centration, in which one's own point of view is set aside, and instead the desire of the other person is acted upon. However, it is especially the end, which makes Babette's 
Feast a true Pope Francis film: Babette reveals that she won the lottery and put the entire sum in the meal. Now poor again, she wants to continue to live as a poor person in the community.

The pope refers to Babette's Feast in a positive way in this document. In an interview with the Italian journalist, Stefania Falasca of the Italian newspaper Avvenire on 17 November 2016, the Roman pontiff referred to the film again, but this time to condemn religious rigidity (referring to the quarreling sectarian community). Certain rigorousness is born of a shortcoming, of wanting to hide one's sad dissatisfaction within an armour (Falasca, 2016). Rules are necessary, but they can make us blind to what really matters. People who are obsessed with rules, can never share in the freedom to which every Christian is called. This might be a hint to what the pope himself experiences in his own context: a certain kind of doctrinal rigour, impeding a pastoral care of mercy.

In Amoris Laetitiae, the pope stresses the positive impact of the film. It gives testimony to true joy. Babette becomes an example for Christian life. In another document of the pope, Gaudete et Laudate (English: Be happy and rejoice), we read that Babette personifies his convictions on holiness. Holiness is a daily duty of every Christian (Pope Francis, 2018: no. 14):

To be holy does not require being a bishop, a priest or religious. We are frequently tempted to think that holiness is only for those who can withdraw from ordinary affairs to spend much time in prayer. That is not the case. We are all called to be holy by living our lives with love and by bearing witness in everything we do, wherever we find ourselves. Are you called to the consecrated life? Be holy by living out your commitment with joy. Are you married? Be holy by loving and caring for your husband or wife, as Christ does for the Church. Do you work for a living? Be holy by labouring with integrity and skill in the service of your brothers and sisters. Are you a parent or grandparent? Be holy by patiently teaching the little ones how to follow Jesus. Are you in a position of authority? Be holy by working for the common good and renouncing personal gain.

\section{Theology in Action}

The pope is right. Personally, I do not understand why Babette is so often compared to Christ. She does not shed any blood in the movie (except the blood of the animals she kills to prepare her supper). She does not die for others. Her satiating meal could easily be compared to the heavenly banquet, prefigured in the Eucharist. Just like the grace the Eucharist imparts, Babette's meal makes the old Protestant community happy again. It also renders us as spectators happy. We share in the grace that the community experiences. Why should she be a riveting Christ-figure? 
Babette does what every Christian should do. As an example for the faithful, she is more Mary than Christ. She understands the message of Christ in Matthew 19:21: "If you wish to be perfect, go, sell your possessions, and give the money to the poor, and you will have treasure in heaven; then come, follow me."

It has often been noted that the film offers ecumenical opportunities, reflection on the shared values of Catholics and Protestants, but is that true? Again, Babette does not theorise about ecumenism; she lives it. She does not want to build bridges between her and the Protestant community by offering new insights on the doctrine of satisfaction or predestination. She offers no compromise about the presence of Christ in the Eucharist. She literally lives the Eucharist and creates a new community, based on dialogue and unity. The question is not at which moment exactly bread and wine become the body and blood of Christ and for how long. Christ becomes present in the visible joy of the community (at the end of the film, after the supper, the congregation dances in the open air) when it is reconciled and unified. Christ is present in the everyday life of every man and woman struggling for unity. This theology is inspired by Louis Marie Chauvet (Chauvet, 1987) and Lambert Leijssen (Leijssen, 2007).

If people start thinking that the film is just about 'being good', they may be wrong. Babette is clearly inspired by her Christian convictions, though this is only shown indirectly through symbolism in the film. She is confident that the Lord is her collaborator in everything she does. Sometimes we see her looking through a window of which the wooden intersection forms a cross. The best example is when she wants permission from the sisters to prepare her dinner. Babette is not only flanked by a porcelain statue of Christ - the famous Christus Consolator of Bertel Thorvaldsen - she also discreetly holds her crucifix necklace, indicating the main reason for her actions.

In this respect, I agree with John Schuler's conclusion (2016:9) of his existentialist analysis of the movie:

Babette's Feast achieves what Kierkegaard treated as impossible: to make the hidden movements of faith visible. A film about goodness threatens to bore its audience; a film about holiness that manages to get it right would seem to be as impossible as roses blooming in December or sitting down to a banquet fit for kings in a Jutland cottage. In Babette's kitchen, we hesitantly sit down to feast holding close to the promise of Psalm 85 quoted throughout the film: Mercy and truth shall meet. Righteousness and bliss shall kiss. 


\section{Conclusion}

If Babette's Feast is able to make hidden movements present, art and religion really have something in common. If this hidden 'thing' is religious, the movie can truly be considered to be a locus theologicus. In this case, Babette's Feast is an illustration of postmodern sacramentology, in which 'real presence' is no longer explained in ontotheological terms. According to the film, Christ's presence is fully located after the peace wish as part of the Catholic liturgy, and not after the consecration of bread and wine (where His presence was situated in traditional theology). If this interpretation is correct, it is all the more surprising that Babette's feast is the pope's favourite.

\section{Bibliography}

Bühler, P. 1998. Le repas, parabole du Royaume? Lecture théologique du Festin de Babette de Karen Blixen. In : G. Bertrand (ed.), Le Goût. Dijon: Université de Bourgogne. pp. 231-237.

Bonfand, A. 2008. Trace du sacré. Catalogue d'exposition Centre Pompidou. Paris: Editions du Centre Pompidou. P.240.

Chauvet, L.M. 1987. Symbole et sacrement: une relecture sacramentelle de l'existence chrétienne. Paris: Cerf.

Curry, T.J. 2012. Babette's Feast and the Goodness of God. Journal of Religion and Film, 16(2): 1-40. Available: http://bit.ly/2JQ3qUB (Accessed 25 January 2019).

Falasca, S. 2016. Papa Francesco: non svendo la dottrina, seguo il Concilio. L'intervista ad Avvenire. 17 November. Available: http://bit. Iy/2H+ISi4 (Accessed 25 January 2019).

Follet, V. 2008. Traces du sacré. Catalogue d'exposition Centre Pompidou. Paris: Editions du Centre Pompidou. pp.233-236.

Goodwin, S.W. 1990. Knowing better: feminism and utopian discourse in Pride and Prejudice, Villette, and Babette's feast. In: L.F. Jones \& S.W. Goodwin (eds.), Feminism, Utopia, and Narrative. (Tennessee: Studies in Literature). Portland, OR: Book News. pp. 1-20.
Leijssen, L.J. 2007. With the Silent Glimmer of God's Spirit: A Postmodern Look at the Sacraments. New York: Paulist Press.

Poddles, M.E. 1992. Babette's Feast: Feasting with Lutherans. The Antioch Review, 50(3):551-565. https://doi. org/10.2307/4612569Pope Francis, 2016. Apostolic exhortation Amoris Laetitia. [Online]. Available: http://bit.ly/2EeECls (Accessed 25 January 2019).

Pope Francis, 2018. Apostolic exhortation Gaudete et Exsultate. [Online]. Available: http://bit.ly/2HHfqVZ (Accessed 27 August 2018).

Schuler, J. 2016. Kierkegaard at Babette's Feast: The Return to the Finite. Journal of Religion \& Film, 1(2): 1-17.

Wright, W.M. 2016. Babette's Feast: A Religious Film. Journal of Religion \& Film, 1(2). Available: http://bit.ly/2HqSpaV 


\section{contributors}

Prof Tomas Axelson is Associate Professor in sociology of religion at Uppsala University. He is also Director of Dalarna University Intercultural Research and Development (DUCID). His field of expertise is vernacular meaning making and world views in everyday life in the crossroad of media and religion with a special interest in fiction film and religion.

Prof Anilita Cloete is Associate Professor in the Department Practical Theology and Missiology, Stellenbosch University. Her research areas includes theology and popular culture, youth culture, religion and media.

Dr Nathan Chiroma is Senior Lecturer and Dean of the School of Theology at Pan Africa Christian University Nairobi, Kenya, and a research associate in the Department of Practical Theology and Missiology at Stellenbosch University. His research areas are mentoring, leadership, spiritual formation and pedagogy within youth ministry.

Prof Margunn Serigsitad Dahle is Associate Professor in Communication and Worldviews, NLA University College (Norway) and Team and Production Director, Damaris Norway. Writer, speaker and consultant, including for the European Leadership Forum and the Lausanne Media Engagement Network. Her research areas are worldview analysis and critique, the Disney Universe, religious/faith education and missiology.

Nathanila Hendriks is Research Associate in the Department of Practical Theology and Missiology at Stellenbosch University. She holds a Master's in Theology focusing on gender and health. She also holds a Master's of Divinity from Stellenbosch University. She is currently enrolled for the Postgraduate Diploma in Theology in Christian Ministry at Stellenbosch University. Her research focuses on the intersectionality of popular culture, gender and theology. 
Prof Hans Geybels is Assistant Professor at the Faculty of Theology and Religious Studies of the Katholieke Universiteit Leuven (Belgium). His main fields of interest are church and communication, the history of Christian art and popular piety.

Prof Jeremy Punil is Professor of New Testament in the Theology Faculty at Stellenbosch University, South Africa. His research focuses on New Testament Hermeneutics, past and present, as well as the intersection of New Testament and Cultural Studies.

Edward C J Wright is Head of Department for Media Literacy Education (MLE), Catholic Religious Education (CRE), and Personal, Social and Career Development (PSCD) at the Secretariat for Catholic Education. He teaches at the University of Malta and is a $\mathrm{PhD}$ candidate at Bournemouth University, focusing on the creativity offered by digital technologies, especially photography and film-making, and how it contributes to meaning-making and identity formation in adolescence. 